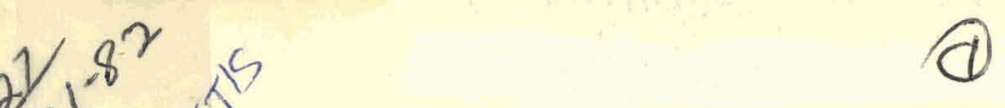

\title{
$\pm-2240$
}

\section{Technical Memo}

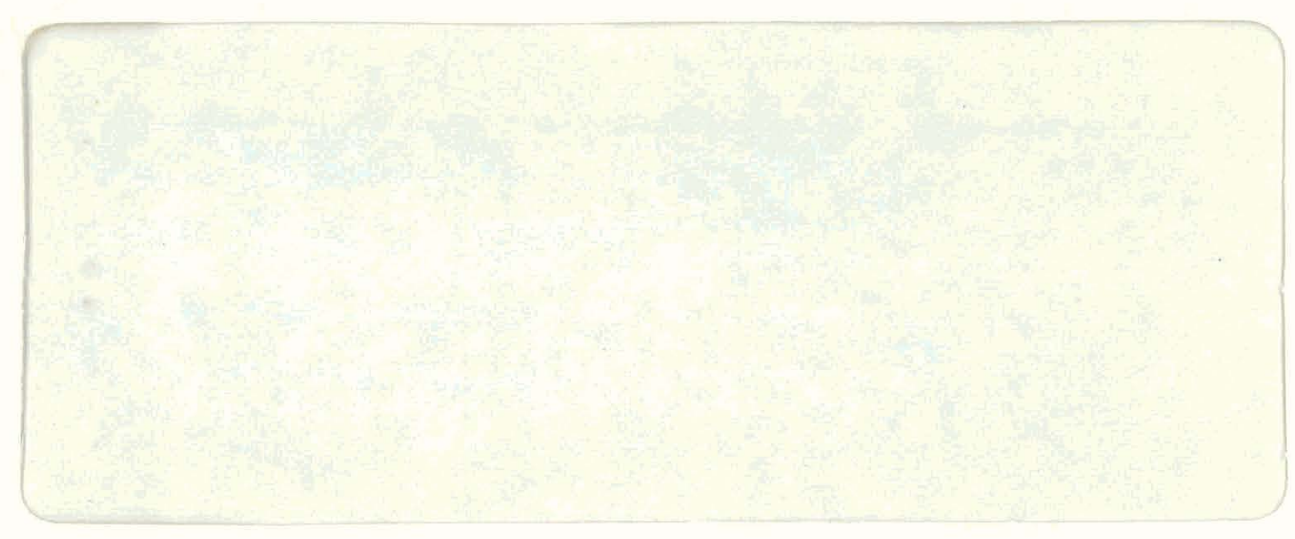

\section{DO RUT MICROFILM COVER}

\section{ARGONNE NATIONAL LABORATORY}

Energy and Environmental Systems Division

prepared for

U. S. DEPARTMENT OF ENERGY

under Contract W-31-109-Eng-38, 


\section{DISCLAIMER}

This report was prepared as an account of work sponsored by an agency of the United States Government. Neither the United States Government nor any agency Thereof, nor any of their employees, makes any warranty, express or implied, or assumes any legal liability or responsibility for the accuracy, completeness, or usefulness of any information, apparatus, product, or process disclosed, or represents that its use would not infringe privately owned rights. Reference herein to any specific commercial product, process, or service by trade name, trademark, manufacturer, or otherwise does not necessarily constitute or imply its endorsement, recommendation, or favoring by the United States Government or any agency thereof. The views and opinions of authors expressed herein do not necessarily state or reflect those of the United States Government or any agency thereof. 


\section{DISCLAIMER}

Portions of this document may be illegible in electronic image products. Images are produced from the best available original document. 


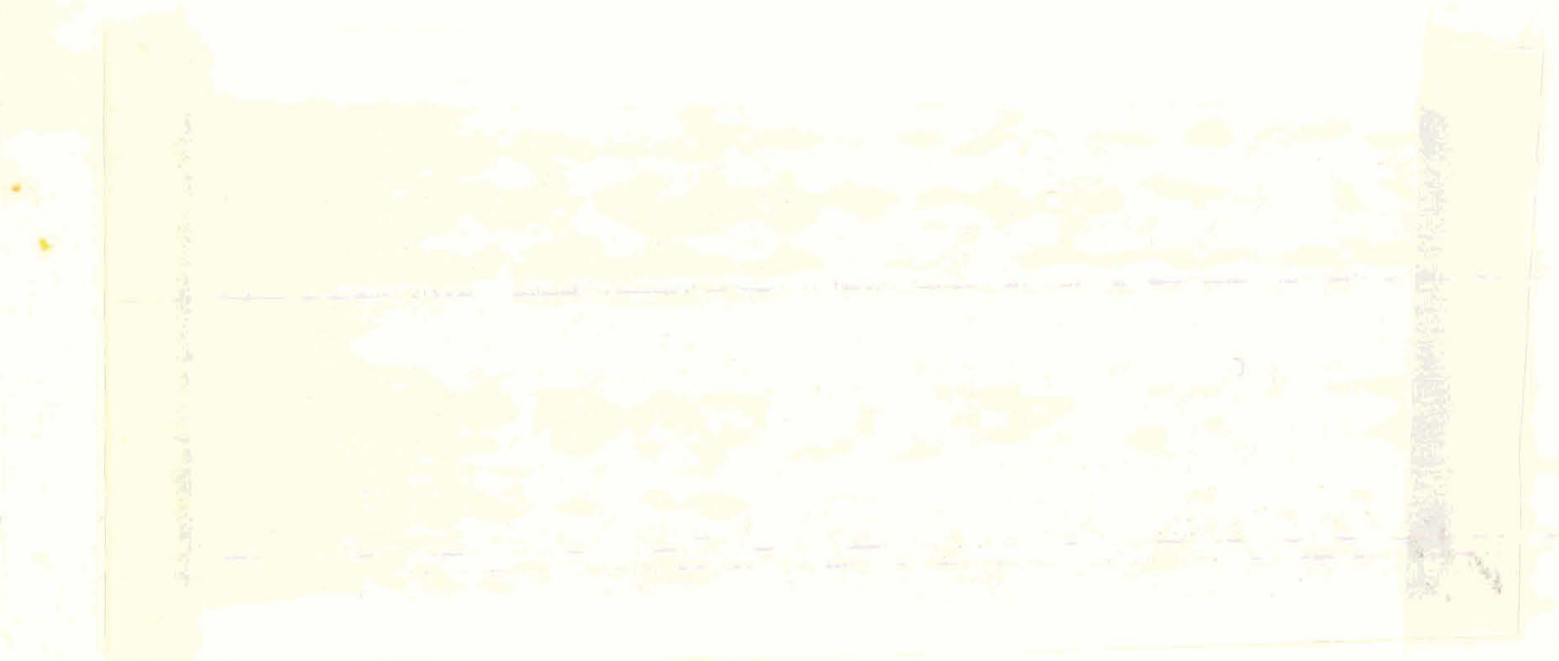

The facilities of Argonne National Laboratory are owned by the United States Government. Under the terms of a contract (W-31-109-Eng-38) among the U.S. Department of Energy, Argonne Universities Association and The University of Chicago, the University employs the staff and operates the Laboratory in accordance with policies and programs formulated, approved and reviewed by the Association.

\section{MEMBERS OF ARGONNE UNIVERSITIES ASSOCIATION}

The University of Arizona

Carnegie-Mellon University

Case Western Reserve University

The University of Chicago

University of Cincinnati

Illinois Institute of Technology

University of Illinois

Indiana University

The University of lowa

lowa State University
The University of Kansas

Kansas State University

Loyola University of Chicago

Marquette University

The University of Michigan

Michigan State University

University of Minnesota

University of Missouri

Northwestern University

University of Notre Dame
The Ohio State University

Ohio University

The Pennsylvania State University

Purdue University

Saint Louis University

Southern Illinois University

The University of Texas at Austin

Washington University

Wayne State University

The University of Wisconsin-Madison

\section{NOTICE}

This report was prepared as an account of work sponsored by an agency of the United States Government. Neither the United States Government or any agency thereof, nor any of their employees, make any warranty, express or implied, or assume any legal liability or responsibility for the accuracy, completeness, or usefulness of any information, apparatus, product, or process disclosed, or represent that its use would not infringe privately owned rights. Reference herein to any specific commercial product, process, or service by trade name, mark, manufacturer, or otherwise, does not necessarily constitute or imply its endorsement, recommendation, or favoring by the United States Government or any agency thereof. The views and opinions of authors expressed herein do not necessarily state or reflect those of the United States Government or any agency thereof.

This informal report presents preliminary results of ongoing work or work that is more limited in scope and depth than that described in formal reports issued by the Energy and Environmental Systems Division.

Printed in the United States of America. Available from National Technical Information Service, U. S. Department of Commerce, 5285 Port Royal Road, Springfield, Virginia 22161 


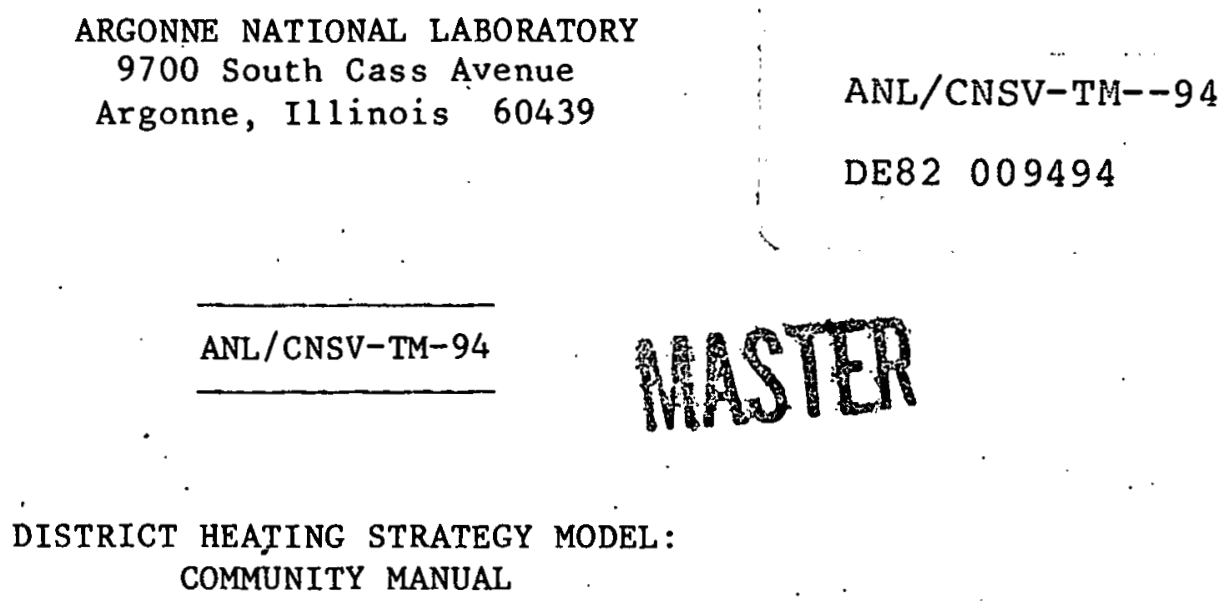

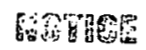

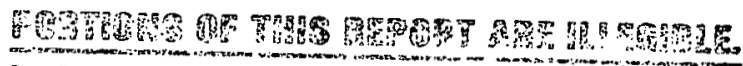

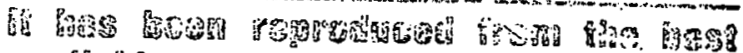

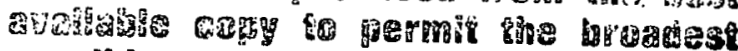

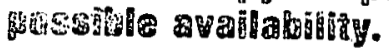

by

R.A. Hrabak, N.F. Kron, Jr., and W.P. Pferdehirt

Energy and Environmental Systems Division

October 1981

This book was pregoed as an acoount of work soonsored by an agency of the United States Government. Neither the Unized Siates.Government nor any ogency thereof. nor any of their employees, makes any

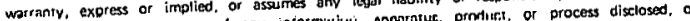

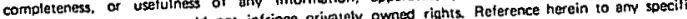
represents that its use vould not int commercial product, process. Or sply ins endorsement, recommendation, of tavoring by the United

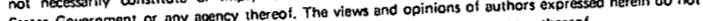

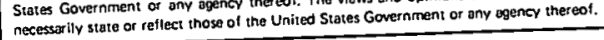

\footnotetext{
work sponsored by
} 
THIS PAGE

WAS INTENTIONALLY

LEFT BLANK 
CONTENTS

ABSTRACT . . . . . . . . . . . . . . . . . . . . . . . 1

1 DESCRIPTION OF THE MODEL AS A WHOLE. . . . . . . . . . . . . . . . . 1

1.1 Introduction. . . . . . . . . . . . . . . . . . . 1

1.1 .1 Specific Purposes of the Model... . . . . . . . . . 2

1.1.2 Role of the Technical Support Representative . . . . . 3

1.2 Overview of the Model . . . . . . . . . . . . . . . . 3

1.3 Descriptions of the Four Modules. . . . . . . . . . . . . . 4

1.3.1 Demand Module. . .. . . . . . . . . . . . . 4

1.3 .2 Supply Module. . . . . . . . . . . . . . . . 4

1.3 .3 Cost Module. . . . . . . . . . . . . . . . 6

1.3.4 Emissions Module . . . . . . . . . . . . . . . 6

1.4 Major DHSM Options Available, by Module ... . . . . . . . . . . 7 .

1.4 .1 General. . . . . . . . . . . ........ 7

1.4.2 Demand Module. . . . . . . . . . . . . . . . . 7

1.4 .3 Supply Module. . . . . . . . . . . . . . . . 7

1.4 .4 Cost Module. . . . . . . . . . . . . . . . . . . 9

1.4 .5 Emissions Module . . . . . . . . . . . . . . . 9

1.5 Assumptions and Limitations of the DHSM . . . . . . . . . . . 9

1.5 .1 Ceneral. . . . . . . . . . . . . . . . 9

1.5 .2 Demand Module. . . . . . . . . . . . . . 10

1.5.3 Supply Module. . . . . . . . . . . . . . . 10

1.5 .4 Cost Module. . . . . . . . . . . . . . . 11

1.5.5 Emissions Module.................. 11

2 DESCRIPTION OF INPUT DATA. . . . . . . . . . . . . . . . . . . . 12

2.1 General Structure of Input Data . . . . . . . . . . . . . 12

2.2 Demand Data File. . . . . . . . . . . . . . . . 12

2.3 Supply Data File. . . . . . . . . . . . . . . . . . . 14

2.4 Coot Data File. . . . . . . . . . . . . . . . . 14

2.5 Emissions Data.File... . . . . . . . . . . . . . 14

3 DESCRIPTION OF OUTPUT DATA . . . . . . . . . . . . . . . . . . 15

3.1 Introduction . . . . . . . . . . . . . . . . . . 15

3.2 Outputs and How They Might Be Reviewed. . . . . . . . . . . . 16

ACKNOWLEDGMENTS . . . . . . . . . . . . . . . . . . . . . . . . . 18

ÄPPENDIX A Glossary of DHSM Terms. . . . . . . . . . . . . . . . . . . . 19

APPENDIX B. DHSM Abbreviations and Computer Acronyms. . . . . . . . . . 27

APPENDIX C Common Conversions between English and Metric Measuring

Units, and Heat-Content Values for Eight Fuels....... . 33 $\therefore: \cdots$ 
APPENDIX D DHSM Default Data, Economic-Analysis Techniques,

and Piping-Cost Equations . ............. . . 35

APPENDIX E Preparation of Data-Input Worksheets. . . . . . . . . . . 47

APPENDIX F Sample Completed Ẉorksheets . . . . . . . . . . . . . 61

APPENDIX G Mapping a DHSM Study Area and Constructing Its

Grid System . . . . . . . . . . . . . . . . . 73

APPENDIX H. Sample Annotated. Computer Output from the .
District Heating Strategy Model . . . . . . . . . . . . . 81

APPENDIX I Standard Industrial and Commercial/Instirntinnal

Classification Codes: Two Sectors or Potential

Importance for DHSM Input and nutput Data . . . . . . . . 119

FIGURES

1.1 Principal Inputs and Outputs of the District Heating

Strategy Model . . . . . . . . . . . . . . . . . 5

D.1 National Energy-Demand Regions... . . . . . . . . . . . 36

E.l Data-Input Packages in Order of Preparation. . . . . . . . . . . . . 47

E.2 Demand-Data Worksheets in Order of Preparation . . . . . . . . . . . 48

E.3 Supply-Data Worksheets in Order of Preparation . . . . . . . . . 50

Blank Ẉorksheets. . . . . . . . . . . . . . . . . . . . . . . 52

Sample Completed Worksheets . . . . . . . . . . . . . . . . . . 63

G.l Minimal Study-Area Map . ... . . . . . . . . . . . . . . . . . . 74

G.2 Cartesian Coordinates with Which Grid Squares are. . . . . . . 76
Superimposed on a Study-Area Map

G.3 A DHSM Grid System Superimposed on a Hypothetical
Study-Area Map . . . . . . . . . . . . . . . . . . . . . . . 77

G.4 The Same Study-Area Map Shown in Fig. G.3, This Time 38

G.5 The Same Map Shown in Figs. G.3 and G.4, This Time
with Other Squares Numbered for Another DHSM Scenario. . . . . . . . 79

Sample Annotated Computer Output Sheets . . . . . . . . . . . . . . . . 82 
2.1 DHSM Input-Data Groups and Their Likely Sources. . . . . . . . . . 13.

3.1 A Possible Division of Output-Review Tasks for the Several Members of a Community's DHSM Assessment Work Group. . . . . . . . . 17

D.1 Default Values Used in the DHSM to Calculate Annual Energy Demands -- by Fuel -- for Space and Water Heating . . . . . . 37

D.2 DHSM Default Values for Cooling Large Buildings. . . . . . . . . . . 37

D.3 Mean Annual Fuel Efficiencies by Building Type and End Use of Energy. . . . . . . . . . . . . . . . . . . . . 38

D.4 Costs of Retrofit and Electricity Replacement by Type of Generating Unit. . . . . . . . . . . . . . . . . . . . 38

D.5 Default Factors Used in the DHSM to Calculate Capital and O\&M Costs of System Components . . . . . . . . . . . . . . . . . 39

D.6 Transmission Cost Coefficients . . . . . . . . . . . . . . . . 4 46

H.1 Classification of Output Data by Community Area to Which They Apply and by Page Format (s) on Which They Are Presented . . . 113 
DISTRICT HEATING STRATEGY MODEL: COMMUNITY MANUAL

\author{
ABSTRACT
}

\begin{abstract}
The U.S. Department of Housing and Urban Development (HUD) and the U.S. Department of Energy (DOE) cosponsor a program aimed at increasing the number of district heating and cooling systems. Because buildings in a district can be heated and cooled more efficiently as a group than individually, a group approach can cut the amount and cost of fuels used for these purposes -- reducing national dependence on fuel imports. HUD and DOE expect construction of such systems to create jobs and spur redevelopment at the local level. Twenty-eight communities have received HUD cooperative agreements to aid in a national feasibility assessment of district heating and cooling systems. The HUD/DOE program includes technical assistance provided by Argonne National Laboratory and Oak Ridge National Laboratory. Part of this assistance is a computer program, called the district heating strategy model, that performs preliminary calculations to analyze potential district heating and cooling systems. The model uses information about a community's physical characteristics, current electricitysupply systems, and local economic conditions to calculate heat demands, heat supplies from existing power plants and a new boiler, system construction costs, basic financial forecasts, and changes in air-pollutant emissions resulting from installation of a district heating and cooling system. This report explains the operation of the district heating strategy model, provides simplified forms for organizing the input data required, and describes and illustrates the model's output data. The report is written for three groups of people: (1) those in the HUD/DOE-sponsored communities who will be collecting input data, and studying output data, to assess the potential for district heating and cooling applications in their communities; (2) those in any other communities who may wish to use the model for the same purpose; and (3) technical-support people assigned by the national laboratories to explain to community personnel how the model is used.
\end{abstract}

1 DESCRIPTION OF THE MODEL AS A WHOLE

\title{
1.1 INTRODUCTION
}

The district heating strategy model (DHSM) is a computer-based analytical tool. It provides technical support for community-level assessments of: systems that can supply heat and cooling from a central source to a group of buildings. The purpose of this report is to help community planners determine how the computer model can assist in their own evaluations and those of their consultants. To this end, the model and its four modules (demand, 
supply, cost, emissions) are described in the body of the report and amplified with practical and theoretical detail in a series of appendixes -- the information being sequenced as follows.

- An overview of DHSM purposes and functions

- Various scenarios -- i.e., assumptions regarding heating and cooling loads, thermal sources, and financial parameters -- that can be analyzed by the model

- As sumptions and limitations contained in DHSM computational procedures

- Instructions for providing required input data

- Suggestions for decision-making applications of the model's output data

- Definitions of terms (Appendix A); DHSM abbreviations and computer acronyms (Appendix B); metric-English conversions (Appendix C); default data, economic-analysis techniques, and piping cost equations used in the DHSM (Appendix D); blank worksheets (Appendix E); sample completed worksheets, illustrating how DHSM input data are prepared (Appendix F); instructions for developing the needed study-area map (Appendix G); a sampling of DHSM computer output (Appendix $\mathrm{H})$; and a listing of standard industrial and commercial/ institutional classification codes (Appendix I).

The report concentrates on how to supply the model with necessary information in order to obtain useful results from it. A description of a test run of the model has been published.*

\subsubsection{Specific Purposes of the Model}

As an assessment and planning tool, the district heating strategy model can serve several purposes; examples include the following:

- It imposes structure on an analysis of local alternatives for district heating and cooling; i.e., the DHSM enables community planners to focus quickly on the types of data to be collected and the typoo of eubordinate analyws to be performed.

- The DHSM prompts a user to study all possible district heating and cooling options. In the process of providing the data necessary to run the DHSM, community planners must specify several district heating and cooling alternatives that are to be evaluated. Alternatives may differ from community to community according to market area, thermal sources, and construction schedule.

\footnotetext{
*Davis, H., et al., National District Heating Program: Generic City District Heating and Cooling from Cogeneration Retrofit, Argonne National Laboratory report ANL/CNSV-TM-65 (Feb, 1981).
} 
- The model enables a user to compare all competing options. Assembling data for the first district heating and cooling option to be assessed requires the greatest effort; other options can then be assessed with a minimum of additional effort.

- Because its economic assumptions are variable, the model enables a user to maximize the benefits of district heating and cooling. For example, the general inflation rate, ${ }^{\dagger}$ as well as escalation rates ${ }^{\dagger}$ for capital, fuel, and operating and maintenance costs, ${ }^{\dagger}$ can be varied -- and their impacts on the cash flow of a district system can be evaluated.

- The DHSM permits evaluating the effects of district heating and cooling on airborne emissions. District heating and cooling systems can significantly decrease air pollution in a community.

\section{1 .2 Role of the Technical Support Representative ${ }^{\dagger}$}

A technical support representative (TSR) has been assigned to communities where feasibility studies of district heating and cooling systems are being sponsored by the Department of Housing and Urban Development and the Department of Energy. Each community receives feasibility-study assistance from its TSR. If the community decides to use the DHSM, the representative continues, as necessary, to acquaint community planners and other technical staff with its use. The TSR functions as the first point of contact for community planners needing questions answered and also as the communication conduit through which input data are received from a community and output data are transmitted to the community. The development of input data for the initial district heating and cooling option to be assessed will be the most difficult and costly task. Once those input data for the model have been collected, the community and its technical support representative can quickly analyze many other options with minimal difficulty and at very low cost.

\subsection{OVERVIEW OF THE MODEL}

The district heating. strategy model is designed to provide information about the respective costs, fuel use, and emissions to air of alternative systems that may be used by a community for district heating and cooling. The DHSM is actually a collection of four separate modules whose computer operations are integrated to perform the required calculations. The modules and their basic functions are as follows.

1. Demand module, which calculates thermal demands to be met by a district heating and cooling system.

Throughout this report, terms not formally defined in the text are marked with a dagger signifying that they are defined in Appendix A. Because of the report's large number of possibly unfamiliar technical terms, this appendix includes other basic definitions as well. 
2. Supply module, which calculates least-cost combination of power plants needing retrofit ${ }^{\dagger}$ and boilers required to meet demands.

3. Cost module, which calculates fuel requirement and costs of meeting thermal demand with and without a district heating and cooling system, and performs cash-flow analysis.

4. Emissions module, which calculates total emissions of various airborne pollutants before and after a district system would be employed.

Each module uses data created in the preceding module or modules. Subsets of the total model can therefore be run only if these subsets begin with the demand module and follow the rest of the order listed above.

\subsection{DESCRIPTIONS OF THE FOUR MODULES}

The principal inputs and outputs of each module are shown in Fig. 1.1. Inputs are described in greater detail in Sec. 2 of this report, outputs in Sec. 3. The inputs and outputs shown in Fig. 1.1 are limited to the major data types required and provided by the program. A brief description of how the input data are used within each module follows.

\subsubsection{Demand Module}

The principal function of the demand module is to estimate the thermal loads required for the conceptual design of a district heating and cooling system. To calculate estimated transmissionl and distribution ${ }^{\dagger}$ costs, tor example, the cost module of a DHSM must "know" the geographical. location of community thermal demands. The user provides the model with this geographically detailed information by tying the information to a system of grid squares, each cell having an area of one square kilometer $\left(\mathrm{km}^{2}\right)$. For every such unit included in the study area, the user must specify the square feet of floor space for each of several building types, e.g., residential- low-density, ${ }^{\dagger}$ residential high-density, ${ }^{\dagger}$ commercial/institutional, ${ }^{\dagger}$ and industrial. ${ }^{\dagger}$ As a rule, floor-space data in this much detail are not readily available; they can often be estimated, however, from aerial photographs, assessor's files, construction and demolition permit files, and field surveys.

The demand module uses the [luvi"space estimates to ealculate annual and peak-daily thermal, demands in each grid square. Peak demands $\dagger$ can be displayed by the program in both tabular and map form; annual demands are displayed in tabular form only.

Other input data that a user needs to provide for the demand module are energy-demand factors and the community's fuel mix. ${ }^{\dagger}$ Encrgy-demand factors for each end use in each building type represent the maximum expected thermal load in Btu per square foot of floor space. Fuel-mix values represent the proportion of the total load currently being met by each fuel type for each end use in each building type. Default values ${ }^{\dagger}$ for thermal-load factors are built into the computer program. Appendix D lists these default values. 
- Floor space for each building type within each grid square

- Annual energy demand factorst for each end use ${ }^{t}$ in each type of building

- Fuel $\operatorname{mix}^{\dagger}$ for each end use in each type of building

- Boundaries of proposed service area

- Escalation rates ${ }^{\dagger}$ for fuel, o\&M, and capital

- Utility pre-tax rate of returnt

- Minimum reserve margint for the district heating and cooling system

- Information on potential thermalsupply units (e.g., location, fuel, fuel price, efficiency, emissions dat a).

- Fuel prices for each end use in each type of building

- Efficiencies of end-use equipment

- Fuel characteristics (e.g., heat cuncent, percenc sulfur, percent ash)

Note: $\dagger$ signifies that term is defined in Glossary (Appendix A).
- Summer ${ }^{\dagger}$ peak daily thermal demand for each grid square

- Winter peak daily thermal demand for each grid square

- Annual thermal-energy demand ${ }^{\prime}$

- Flectricity generating capacity displaced by district heating and cooling due to decreased electrical space conditioning and water heating

- Competing thermal sources ranked and selected on basis of providing thermal capacity needed at least $\cos t$
- Fuel ise and fuel costs, before and after installation of a district heat ing and cooling system, for each end use in each type of building

- Capital and O\&M costs ${ }^{\dagger}$

- Cash flow, net benefits, $\dagger$ savingsto-investment ratio, $\dagger$ and payback period of a district heating and cooling system
- Annual airborne emissions (particulates, $\mathrm{SO}_{\mathrm{x}}$, and $\mathrm{NO}_{\mathrm{x}}$ ) at central thermal-supply units, before and after district heating and cooling is installed

MODULE

Fig. 1.1 Principal Inputs and Outputs of the District Heating Strategy Model 


\subsubsection{Supply Module}

To meet the loads computed by the demand module, the supply module compares and selects the most appropriate thermal sources. The user decides which grid squares, building types, and end uses specified in the demand module are to be serviced by district heating and cooling. Based on input data related to economic parameters and candidate thermal sources, the program ranks and selects the sources that provide the necessary total thermal capacity at the lowest cost. Sources the model can consider include cogenerating utility plants, thermal-only boilers, and geothermal ${ }^{\dagger}$ facilities.* $^{*}$

The supply module ranks competing thermal sources on the basis of the present value of their costs to deliver energy to the boundary of the service area. The computed costs include retrofit of existing generating plants, replacement of electrical capacity (electrical replacement costs ${ }^{\dagger}$ ) lost because of cogeneration ${ }^{\top}$ retrofit, plant operation and malncenance (OQM), ${ }^{\dagger}$ did transmission-pipe construction and $O \dot{M}$. Transmission-pipe costs compuled in the supply module are for the straightline distance between the thermal source and the nearest boundary of the service area. Transmissiun and distribution costs within the service area itself are computed in the cost module.

\subsubsection{Cost Module}

To compute total costs for energy used in a district heating and cooling system, the cost module draws primarily from data generated in the demand and supply modules. These costs are compared with those for the same services without a district system. "Before" and "after" fuel costs are expressed in dollars per million Btu of delivered energy. As part of computing energy costs for a district system, the cost module calculates estimated costs of transmission and distribution within the service area and the costs of retrofiteling end-use equipment (plant retrofit costs) in customer buildings. Uther economic outpuls provided by the coot module are a cash-flnw analysis, a savings-to-investment raclot of the dislsict heating and cooling system, and the system's discounted payback period.

\subsubsection{Emissions Module}

The emissions module analyzes the annual effects of a district heating and cooling system on the community's alrborne emissiums. Included in the analysis is a determination of such emissions before and after changing over to a district system. The emissions examıned include the principal cumbis tion-related pollutants: particulatco, eulfur oxides, and nitrogen oxides. Annual emissions of these airborne pollutants are based on the types, quantity, and quality of fuel consumed; and also on the type of pollution-control equipment used, if any. Emissions are calculated for each thermal source in a district system, as well as for end-use fuel combustion by consumers.

* If a community currently lacks capacity from candidate supply sources at or below a use-specified maximum cost per million Btu, the supply module assumes a boiler is constructed to meet peak demands. 
Input data that need to be provided to the emissions module are the average seasonal-efficiency values for end-use equipment and such fuel characteristics as heat content and pollutant concentration. Default values, listed in Appendix D, are included in the computer program.

\subsection{MAJOR DHSM OPTIONS AVAILABLE, BY MODULE}

Computer models such as DHSM allow the user to easily assess changes in the results caused by changing assumptions and conditions. Major options are available for each DHSM module, enabling a user to specify different district heating and cooling scenarios and the types of analyses to be performed. A user should be aware of these options in order to obtain the model's full benefits.

\section{4 .1 General}

A district heating and cooling system would normally be put in place over a period of time, in phases. The DHSM can be used to study phased expansion of both the district service area and its thermal-supply capacity. Each major phase requires a separate run of the DHSM computer model. Costs computed by the DHSM may need to be adjusted to ensure that transmission and distribution costs are not overestimated.

\subsubsection{Demand Module}

Demand data can be altered in a number of respects, as indicated by the following possibilities.

- Geographic boundaries of the district heating and cooling service area can be varied.

- Building types and end uses to be serviced can be varied.

- Scaling factors ${ }^{\dagger}$ can be used to adjust original floorspace estimates. Such adjustments may be appropriate if oignificant conotruction or demolition io cupceted bcfore completion of the district system.

- Scaling factors can be used to adjust energy-intensity factors. Adjustments of this sort can be used to analyze the effects of consumer conservation measures, or to calibrate demands calculated by the model should they vary from demands estimated using other data sources.

\section{$1: 4.3$ Supply Module}

The supply module is very versatile, allowing the user opportunities to readily change thermal-source locations and characteristics. Several opportunities illustrate this versatility.

- Thermal-reserve ${ }^{\dagger}$ requirements can be varied.

- A user can eliminate specified thermal-source candidates from individual runs. 
- Thermal-supply units in existing district steam systems can be analyzed in the process of selecting thermal sources for district heating and cooling.

- Five separate types of thermal-supply units can be evaluated and ranked for use in district systems: 1) singlecase turbines, $\dagger$ 2) multicase turbines, $\dagger 3$ ) combustion turbines, 4) conventional boilers, and 5) geothermal sources. Existing steam cogenerators are treated by the model as two units, one a single-case turbine and the other a conventional boiler.

- Fuels used by thermal-supply sources can be varied to examine effects (e.g., economic and fuel consumption) of such modifications. Cost of equipment modification for fuel switching are not computed by the model, however.

- A user can determine the cost of replacing electrical generating capacity ('replacement capacity') lost due to cogeneration retrofit -- that is, the percentage of lost capacity actually charged to the district heating and cooling system.

- Thermal-supply units ${ }^{\dagger}$ at the same station ${ }^{\dagger}$ that use the same fuel can be analyzed and ranked as a group or individually.*

- Thermal-supply units are selected until the annual thermal-energy supply meets or exceeds a service area's annual thermal requirements. It is unlikely that the requirements and the supply will match exactly. In the case of an inexact match, operating and maintenance, fuel, and capilal custs of the last selected group of identically fueled supply units are decreased to correspond to the percent of the unit's annual thermal-energy production actually used for district heating and cooling.**

*Each user-specified group of units is referred to as a "station fuel group." The advantage of combining several units in the same group is that the units are assumed to share the same transmission line to the service area. The disadvantage of some such groupings, however, is that an efficient, low-cost thermal-supply unit may be dropped from competition if it is included in a group containing several inefficient and expensive thermal sources.

** This approximation may be insufficient in some cases, particularly if only a small percentage of a group of supply units is required for district heating and cooling. Methods of dealing with this problem are as follows.

1. If a station's last selected group of identically fueled supply units comprises several units, the units can be considered as smaller groups or even individually.

2. A service area can be extended or contracted to provide a better match between thermal requirements and available supply.

3. The group of identically fueled units selected last at a station can be removed from consideration and replaced with a boiler of the appropriate capacity. 
- A user can specify whether "high-cost" or "low-cost" estimates are to be prepared. These form the upper and lower bounds, respectively, for expected costs. All costs for an individual run must correspond either to high- or lowcost assumptions, exclusively.

\section{4 .4 Cost Module}

Economic and cost parameters that can be altered by a user include:

- Cost-escalation rates for each fuel;

- Startup and completion dates for construction period;

- Expected lifetime of a district heating and cooling system;

- Utility pre-tax ${ }^{\dagger}$ rate of return; ${ }^{\dagger}$

- Discount rate; ${ }^{\dagger}$

- General inflation rate;

- Allowance for funds used during construction (AFC rate ${ }^{\dagger}$ ); and

- Capital-recovery period for the district system.

\subsubsection{Emissions Module}

The average sulfur and ash content of fuels can be varied.

\subsection{ASSUMPTIONS AND LIMITATIONS OF THE DHSM}

The major assumptions inherent in a DHSM analysis, as well as their implications and accompanying limitations, șhould be familiar to a user for two reasons: 1) so that proper input data are provided and 2) so that the model's results are properly interpreted.

\section{5 .1 General}

The DHSM is not an optimization model. That is, the model analyzes user-specified district heating and cooling scenarios but does not itself determine the "best" district-heating market area, construction build-out plan, etc. Community planners are expected to use the model's results for several scenarios so that they can determine the heating and cooling system most desirable for a district.

$\therefore$

$\therefore$ The medium used to distribute heat to the buildings in a district is hot. water, at approximately $250^{\circ} \mathrm{F}$. Hot water, rather than steam, would constitute the most economical heat-distribution medium for most district heating applications. A district system is also assumed to require no significant modifications to match the dispatching requirements of electricitygenerating stations. 


\subsubsection{Demand Module}

The model assumes that the principal thermal demands of a district heating and cooling system are for space heating and domestic water heating. Promising district heating systems can be subsequently extended to meet cooling demands from large buildings and some low-temperature demands from industrial processes.

\subsubsection{Supply Module}

An electric utility's generating plants, retrofitted for cogeneration, represent the major potential source of thermal energy within a district heating and cooling system. Where necessary, thermal-only boilers can also be used. With proper modifications, such other thermal sources as solar collectors, and incinerators that recover heat, can also be analyzed. To the model, these other thermal sources are represented as "boilers" with atypical costs for capital, operation and maintenance, and fuel.

The electricity-generating capacity of single-case turbine units is assumed to be permanently decreased as a result of retrofitting them for cogeneration. However, each generating unit is assumed to produce as much electricity both during the winter and annually as it did normally before retrofit for cogeneration operation.

Groups of identically fueled thermal-supply units at a station are ranked on the basis of average annual (discounted) cost per million Btu thermal energy delivered to the boundary of the service area. Such fuel groups are selected until the total annual thermal-energy production meets or exceeds the annual thermal-energy requirements of the serviçe area. Onçe this condition is met, the total thermal capacity of all station fuel groups is compared with total peak demands -- and if additional capacity is required, existing thermal-only boilers are selected or a new boiler of sufficient capacity is assumed to be constructed.

Thermal-supply units that burn different fuels but are being considered for use at the same station cannot be combined in the same "station fuel group." Costs might therefore be exaggerated, since each station fuel group is assumed to have its own thermal transmission pipe to the service area.

The model does not currently have the ability to analyze thermalstorage facilities for a district heating and cooling system.

Opcrating and maintenance costs and plant-retrofit costs are assumed to be proportional to the thermal capacity of a supply unit. Also, the costs of replacing electricity-generating capacity lost due to cogeneration retrofit are based on the costs of installing new combustion turbines of an appropriate size to replace the lost capacity. The user can decide, based on local circumstances, ${ }^{*}$ the fraction of these replacement costs that should actually be charged to the district heating and cooling system.

\footnotetext{
*For example, if the electric utility has surplus capacity during the winter months (i.e., at the time of peak demands on the district heating and cooling system), none or only a small portion of the charge may be applicable.
} 


\subsubsection{Cost Module}

All costs are estimated using factors derived from 1980 costs. These should be adjusted with escalation rates for capital and operating and maintenance costs. Individual components of $O \& M$ or capital costs cannot be adjusted separately.

The investment costs of a district heating and cooling system can include capitalized interest during construction. All cash flow begins with the first year of system operation. Tax effects and insurance are not included in capital carrying charges.

\subsubsection{Emissions Module}

All emission impacts are computed on an annual basis. (However, current Environmental Protection Agency regulations include $3-\mathrm{h}$ and $24-\mathrm{h}$ standards; these can occasionally be violated even though annual emissions remain at acceptable levels.)

All specified thermal sources in a district system are treated as point sources. ${ }^{\dagger}$ All other pollutant sources in the district are aggregated by grid square and are treated as area sources. $t$

The program considers whether individual point sources are subject to the Federal government's New Source Performance Standards. 'For those that are, the applicable pollution-control equipment is assumed. 
2 DESCRIPTION OF INPUT DATA

The district heating strategy model requires a precisely formatted input. Community planners desiring to use the model must complete a series of data forms. The forms describe community characteristics in such a way that DHSM calculations can be performed. At a minimum, planners must define the spatial distribution of those community land uses that may be served by a district heating and cooling system. Such a defining process identifies economic, cost, and fuel characteristics associated with each potential service area. In many instances, the specific data required for a communicy may be obtainable only with considerable effort. The DHSM stores many default values, or rules of thumb for adjusting a specific program to a community's climate. Default values are 1 isted in Appendix $D$.

Reranse a Phase 1 study of district heating is intended only as an estimate of system feasibility, some inaccuracy of Input data llay be acceptable, especially if expensive data-gathering would be required to achieve highly precise data. The best available data are sufficient in the early phases of an assessment study of district heating and cooling. Estimates can be refined in later work, when sufficient known potential for a district system warrants more detailed and costlier investigation. The main groups of data needed by the DHSM, and their likely sources, are summarized in Table 2.1 .

\subsection{GENERAL STRUCTURE OF INPUT DATA}

Each DHSM module -- demand, supply, cost, and emissions -- requires input data from the community. The four data "files" are:

- Demand data file (DDF),

- Supply data file (SDF),

- Cost data file (CDF), and

- Emissions data file (EDF).

Blank worksheets used to assemble data for these files are shown in Appendix E. Samples of completed worksheets, with detailed explanations, are provided in Appendix F. The forms are marked in the upper right hand corner with $D, S$,

$\mathrm{C}$, or $\mathrm{E}$, respectively, to distinguish them at a glance. Nine different kinds of forms are used in the four data files.

\subsection{DEMAND DATA FILE}

The demand data file consists of three parts:

1. A community map with a grid system ${ }^{\dagger}$ made up of $1-\mathrm{km}^{2}$ cells superimposed on it (see Appendix G);

2. A copy of the "Community Demand Data Sheet;" and

3. As many copies of the "Grid-Square Demand Data Sheet" as there are grid squares on the map, up to a maximum of 450. For grid squares without significant thermal demand 
Table 2.1 DHSM Input-Data Groups and Their Likely Sources

Data Group/Selected Examples

Community physical characterisitics

- area map

- area grid system

- square footage by structure type, each grid square

- fuel efficiencies ${ }^{\dagger}$ of end-use ${ }^{\dagger}$ equipment, by fuel and building type

Community energy-demand characteristics

- heat and fuel demands by building type and end use

Grid-square energy-demand characteristics

- fuel mixt by building type and end use

Community financial assumptions (for scenarios ${ }^{\dagger}$ )

- general inflation ratet for $x$ years in future

- price-escalation rates for individual fuels and other recurring system needs

Utility financial data

Air-pollution information

Electricity-generating plant data

- locations of plants

- data un individual generating units: seasonal capacity factors, fuel costs, peak capacities, airborne emissions, fuel pollutant contents

Scenario As sumptions

- cost escalation rates, to he applied by grid square
Likely Source or Sources

Planning departments, zoning departments, assessor's files, regional planning agencies, housing or industrial development agencies

Energy office, utilities, planning departments

Energy office, utilities, planning Departments

Utilities, banks, and other financial institutions, public utilities commission

Utilities, public utilities commission

Utilities, air pollution control officials

Utility engineers, air pollution control officials

Decision of assessment work group 
-- e.g, undeveloped open space and agricultural areas -no data sheets are necessary because the squares need not be serviced by a district system.

Most of the information in the file describes the end-use demands for energy in the community and the mix of land uses in the grid squares. Creation of this file requires detailed local knowledge and judgment, both of which are only available within the community itself.

\subsection{SUPPLY DATA FILE}

The supply data file provides the DHSM with the data required to determine a minimum-cost system for supplying heat to selected buildings in a district. For each model run, the user specifies a service area, a group of thermal-supply candidates, and $\dot{a}$ financial scenario. ${ }^{\dagger}$ The user provides information about existing electric power plants and possible future units. Any existing district steam systems are also described here. The user-specified service-area scenario consists of a geographic area with good district heating potential -- i.e., a subset of the grid squares and a subset of the building/end-use sectors within that area.

The four data sheets (five forms) used for placing input in the supply data file are:

- "Scenario Definition Sheet,"

- "Boundary Identification Sheet" (optional),

- "Station Data Sheet," and

- "Unir Definition Dara Sheer" (rwo pages).

For clarity, these may be considered as two packages. The first package describes the overall scenario and the boundary of the area to be serviced if it is smaller than the entire community. The second package describes all existing and any planned electric power plants and equipment. For each.station, an "Electric Generating Station Data Sheet" must be completed along with a set of "Unit Definition Data Sheets" for each unit at the station.

\section{?.4 COST DATA FII.F,}

This data file is simple compared to the previous ones. The "Fuel Cost Data Sheet" requires that each of five major fuel types be specified in terms of its cost in dollars permillion Btu for each of the six possible end uses.

\subsection{EMISSIONS DATA FILE}

The "Emissions Input Data Sheet" requires a list of typical heating equipment efficiencies for each fuel type in each end-use sector. This table may be left blank if the user chooses to use the model's default values (see.Appendix D). Various data relating to oil and coal characteristics and use sector are necessary to estimate emissions. The heat content of input fuels must also be specified. 
3 DESCRIPTION OF OUTPUT. DATA

\subsection{INTRODUCTION}

The DHSM provides two types of output data:

1. Data that describe the inputs by simply printing out items the computer programmer put into the machine, and

2. Data that represent calculations performed by the computer. A separate output exists for each scenario being studied.

Type 1 outputs, or "data echoes," are useful to community planners because they show the input used to describe the community characteristics and assumptions made for the scenario being run. Data echoes provide the information needed to check the validity of the input data.

Type 2 outputs, or "calculation results," present the following items.

- Calculated heat demands for each grid square in the community.

- Summary of heat demands for the entire community.

- Map of thermal densities, depicting quantity of peak heat demand for each of the community's grid squares.

- Total heat demands for the grid squares included in the scenario; the stations that should be used to supply heat, in rank order based on cost of supply; the new boiler capacity that may be needed; and the stations that are less desirable to convert to district heating because of probable high costs.

- Fuel use and airborne emissions at each community station and in each grid square, before and after implementation of the scenario's district heating systems; plus a summary of fuel uce and cmisions for the entire community.

- Simulated capital and annual costs of each scenario's district heating system, the changes in fuel use caused by conversion to district heating, and financial ratios useful in determining the value of district heating as an investment opportunity.

In testing the DHSM, Argonne National Laboratory made several computer runs using data from real communities. To illustrate the output format, a portion of the detailed outputs from one scenario in Piqua, Ohio, is presented in Appendix H. Explanatory comments accompany each important category of output in the Piqua example.

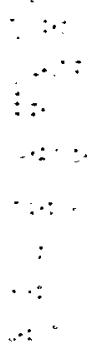




\subsection{OUTPUTS AND HOW THEY MIGHT BE REVIEWED}

Al1 portions of DHSM output should be of interest to all members of an assessment work group ( $A W G$ ). Considering the large volume of output data, however, it may be desirable to divide the task of reviewing them among the AWG members. One possible division of labor is shown in Table 3.1 .

With tasks apportioned in this manner, the engineering staff could use the demand and supply outputs to verify its own figures or to discover where scaling factors and other data inputs to the model might be made more realistic. Utility people interested in assessing demands in their service areas should also verify that the data match local experience and projections.

Utility representatives should probably also check the data on stations recommended for cogeneration conversion to verify ( 1 ) whether deratings are critical to the electricity supply system's pertormance and (2) whether costs of replacing lost capacity agree with local experience.

Portions of the supply and cost modules contain data relating to the financial needs and viability of the proposed system. The AWG bankers, municipal finance people, and utility financing specialists can examine the figures to determine how the needed capital can be raised and whether the return on investment is high enough to attract necessary private and public financing.

Prospective consumers of district energy service should probably examine the parts of the cost module that show alternate fuel prices and decide if the costs for district heating are enough lower than current (and projected) fuel prices to justify their continuing interest.

AWG members involved in air-pollution control should review the emissions output daca and delermite whether the air quality effecto of the district heating system are acceptable. The emissions output per grid square can help in locating potential "hot spots," where high emission concentrations may create problems.

Each member of an assessment work group should have a reasonably good grasp of each scenario being considered. A scenario provides llie basis for computer outputs; it can be changed by replacing its assumptions with ones judged to reflect community conditions more reallstically. 
Table 3.1 A Possible Division of Output-Review Tasks for the Several Members of a Community's DHSM Assessment Work Group

\begin{tabular}{|c|c|c|}
\hline $\begin{array}{l}\text { AWG Member } \\
\text { (Illustrative } \\
\text { Representation) }\end{array}$ & $\begin{array}{l}\text { Likely } \\
\text { Focus of } \\
\text { Interest }\end{array}$ & Appropriate Task or Tasks \\
\hline Project manager & $\begin{array}{l}\text { Entire } \\
\text { output }\end{array}$ & $\begin{array}{l}\text { Gain overall conceptual familiarity with out- } \\
\text { put to improve delegation of review responsi- } \\
\text { bilities and to understand the whole project }\end{array}$ \\
\hline \multirow{3}{*}{$\begin{array}{l}\text { Utility represen- } \\
\text { tative (especially } \\
\text { electric utility) }\end{array}$} & $\begin{array}{l}\text { Demand } \\
\text { data }\end{array}$ & $\begin{array}{l}\text { Compare against the utility's own figures, to } \\
\text { improve scenario assumptions }\end{array}$ \\
\hline & $\begin{array}{l}\text { Supply } \\
\text { data. }\end{array}$ & $\begin{array}{l}\text { Check feasibility of proposed power plant con- } \\
\text { versions, especially to determine if capacity } \\
\text { losses can be accepted and if costs for capac- } \\
\text { ity replacement match local experience; verify } \\
\text { fuel-cost assumptions }\end{array}$ \\
\hline & $\begin{array}{l}\text { Cost } \\
\text { data }\end{array}$ & $\begin{array}{l}\text { Compare capital and ongoing costs against } \\
\text { those of similar local ventures }\end{array}$ \\
\hline \multirow[t]{2}{*}{ Elected official } & $\begin{array}{l}\text { Demand } \\
\text { data }\end{array}$ & $\begin{array}{l}\text { Check scenario against development patterns } \\
\text { for correctness; determine political feasi- } \\
\text { bility of replacing present system with dis- } \\
\text { trict heating and cooling system }\end{array}$ \\
\hline & $\begin{array}{l}\text { Cost- } \\
\text { of- } \\
\text { supply } \\
\text { data }\end{array}$ & $\begin{array}{l}\text { Check available public financing strategies } \\
\text { for a project of this magnitude; discuss with } \\
\text { public works departments whether piping-cost } \\
\text { estimates match local experience; determine } \\
\text { availability of outside funding; check local } \\
\text { and state regulatory structure for possible } \\
\text { barriers to the project }\end{array}$ \\
\hline $\begin{array}{l}\text { Banker or other } \\
\text { finance specialist }\end{array}$ & $\begin{array}{l}\text { Cost } \\
\text { and } \\
\text { supply } \\
\text { data }\end{array}$ & $\begin{array}{l}\text { Analyze reasonableness of returns on invest- } \\
\text { ment to determine if capital, either private } \\
\text { or public, can be attracted; check interest of } \\
\text { businesses to be supplied and availability of } \\
\text { money for them to convert to district heating; } \\
\text { check inflation and interest rates }\end{array}$ \\
\hline $\begin{array}{l}\text { Environmental } \\
\text { specialist }\end{array}$ & $\begin{array}{l}\text { Emis- } \\
\text { sions } \\
\text { data }\end{array}$ & $\begin{array}{l}\text { Check for hot spots and sensitive areas nearly } \\
\text { or actually violating standards; consider } \\
\text { whether additional emissions may be offset } \\
\text { by district reductions in use of onsitet fuel }\end{array}$ \\
\hline $\begin{array}{l}\text { Consumer repre- } \\
\text { sentat ive }\end{array}$ & $\begin{array}{l}\text { Cost } \\
\text { and } \\
\text { demand } \\
\text { data }\end{array}$ & $\begin{array}{l}\text { Compare costs of individual and district heat- } \\
\text { ing systems; check if demand calculations } \\
\text { appear correct, given local experience; verify } \\
\text { financial assumptions }\end{array}$ \\
\hline
\end{tabular}


ACKNOWLEDGMENTS

The authors of this report received substantial technical assistance from Allen Kennedy, Allen Davis, Howard Davis, Jerry Kuzanek, Steve Grammel, Kim Suchy, and Elliott Levine -- all of Argonne's. Energy and Environmental Systems Division.

Work completed under contract to Argonne by the Energy Systems Research Group, of Boston, formed the basis for the district heating strategy model. Steve Bernow of ESRG was an invaluable resource throughout development of this report.

Grateful appreciation is also expressed to. Jo Ann Lawlor and Debbie.Gibson for their superb typing and word-processing services. Editing was completed by John Cleland. 
APPENDIX A

Glossary of DHSM Terms

absorption cooling space cooling (air conditioning) that uses heat to drive a special refrigeration machine, producing cold water for cooling

adjusted efficiency the fuel efficiency of heating equipment for various building types and fuels

AFC rate (allowance for funds used during construction) the percentage rate charged for borrowing money during the period of constructing a district heating and cooling system

annual costs. all costs incurred during the course of a corporation's fiscal year

area source (of air pollution) an aggregation of smal1, ill defined pollution sources distributed throughout an area (see also point source)

arithmetic average the sum of all values in a group of numbers divided by the: number of elements in the group

avoided costs in the district heating and cooling model, fuel and hardware costs not incurred because a district heating and cooling system has been installed (but which would otherwise have been incurred)

base fuel fuel required at a station under normal operation, before retrofit for district heating

baseload boiler a hot water boiler that services continuous thermal demands

building end-use sector a certain energy requirement of a certain type of building; for example, one building end-use sector is low-density residential space heating; another is industrial space heating

building retrofit costs costs incurred in changing individual heating and cooling equipment in a building to the kind needed by a district heating and cooling system

capacity credit the amount of electrical generating capacity (of peaking equipment) rendered unnecessary when energy demands formerly supplied by elelctricity are supplied by a district heating and cooling system

capacity factor (CF) the ratio of the average power load of an electric power plant to its rated capacity; $C F=M W / y r$ generated, divided by the product of the generating plant's MW rating and $8760 \mathrm{~h}$

capacity fraction, district steam-system scenario the amount of peak thermal power, or capacity, of an existing district heating system that services grid squares in a scenario (see also peak thermal capacity, grid square, secnario) 
capacity loss. (see derating)
$\begin{gathered}\text { capital costs. money spent to purchase and install the district plant and } \\ \text { equipment }\end{gathered}$

capitalization of interest the interest costs added, during construction, to a project's capital costs

capital-recovery period the time period over which capital costs of a district system are amortized, or annualized

cogeneration the simultaneous production of electricity and useful heat

combustion turbine (see turbine)

commercial/institutional a range of service and other nonindustrial building Lypes; see Appendix I fur funcliunal breakdown used by Llie DHBM

cooling degree-days (see degree-day)

cost ceiling in the model, the cost per million Btu above which a unit will not be converted to district heating and cooling

cumulative net benefits lifetime benefits minus costs

current dollars today's dollars; the DHSM, having been written in 1980 , assumes a "current" dollar to be one as it was valued in 1980; inflation since that time may be taken into account by the user

data file in the model, a package of information, the items of which may be transferred from one part of the model to another (see also record)

decimal fraction a fractional part of the number one; for example, $2 b \%$ may be expressed as the decimal fraction 0.25

default an estimate used by a computer model if no other estimate is provided by the DHSM user

degree-day the product of one day and the number of degrees Fahrenheit below $65^{\circ} \mathrm{F}$ of the mean temperature on that day; thus, on a day when the mean temperature is $40^{\circ} \mathrm{F}$, there are 25 degree-days; the degree-day unit is used to eliminate the weather variable in determining heatingload efficiency and in predicting fuel consumption

demand factor the energy demands for a type of building expressed in thousands of British thermal units per square foot (Btu/ft ${ }^{2}$; the factor is for service demand, or the quantity of energy actually needed, rather than for fuel demand -- fuel demand being higher than service demand because of equipment inefficiencies

derating the loss in peak electrical generating power (capacity) caused by conversion of electric generating equipment to cogeneration 
design temperature for cooling at a given location, design temperature is the outdoor air temperature equaled or exceeded only. $1 \%$ of the time; for: heating, the design temperature is the temperature below which outdoor air drops only $2.5 \%$ of the time

discount rate interest rate used to reflect the time value of money

discounted payback period the time period required for cumulative project savings to equal initial investment in the project; future savings are discounted at a specified rate during this period, whereas savings or cash flows are not discounted during a single payback period

dispatching (of power plants) the schedule by which a group of power plants operates -- the scheduling is mainly concerned with the quantity of energy to be delivered and the timing of delivery, both factors being based on functional and economic considerations

distillate oil light oil such as diesel fuel and home heating oil, classed by a number of $1,2,3$, or 4 (see also residual oil)

distribution costs capital costs incurred in constructing thermal pipes from the transmission or loop piping to individual buildings

diversity (in demand) in computer modeling of power and energy demands, the models often assume all similar structures have the same hourly demand pattern; however, because experience has shown that not all occupants behave identically, the DHSM multiplies a diversity factor by the calculated demand peaks to account for such individual differences; the diversity factor lowers calculations for power and energy

electrical credits the annual amount of electricity previously used (for space heating and cooling and water heating) that is no longer required after district heating and cooling services are substituted for it

electricity-replacement costs capital costs incurred to build new electrical generating units to replace the capacity lost by derating of existing power plants.

end use the purpose for which energy is consumed by consumers; "end user" refers to the consumer who operates energy-consuming equipment

energy fraction, district steam system scenario anount of the annual thermal output of an existing district. steam system that services grid squares in a scenario

escalation rate annual percentage increase in the price of a prodirt (see also real escalation rate and general inflation rate)

final demand (also final end-use demand). requirements for energy services within a building; final demand in the model consists of an actual Btu value based on space-heating, space-cooling, or process-heat needs -unlike fuel demand (the Btu value of fuel input to a furnace, for

$\therefore$ example), final demand is the amount of heat needed from the furnace to maintain residential comfort or industrial process requirements 
fixed charge rate the rate used to convert the present value of all annual capital charges to a stream of uniform annual charges; see Appendix $D$ for more detailed explanation

fraction electrical credits electrical credits assigned to each cogenerating station in a district system; the fraction is computed by dividing total electrical credits by the total annual amount of electricity generated at all stations assumed to be retrofitted for cogeneration (see also electrical credits)

fuel efficiency ratio of the heat being consumed in a system to provide service and the heat content of the fuel used

fuel mix the division of fuels used within a building type, presented as the fraction of floor space of each building type using each fuel (for the scaling of a fuel mix, see scaling factor)

general inflation rate general annual increase in the price of goods and services; the annual change in the price deflator of the gross national product and the annual change in the consumer price index are two widely accepted measures of the general inflation rate

geothermal pertaining to heat within the earth

grid square a single $1-\mathrm{km}^{2}$ cell in a community grid system (see grid system)

grid system the matrix of grid squares into which a community is spatially divided for purposes of locating such features as power plants, calculating spatial distribution of energy demands, and estimating spatial distribution of airborne emissions (see also grid square)

heating degree-day (see degee-day)

heat rate (see thermal heat rate)

inflation rate (see general inflation rate)

industrial buildings used for construction or manufacturing purposes; see Appendix I for functional breakdown used by the DIISM

in-service year the first operating year of a dislict heating and cooling system

large building (in terms of cooling demand) a high-rise office, residential, or industrial building with a cooling demand of 100 ton or more.

lifetime costs in the model, the total costs of all fuels, operation and maintenance, and capital incurred after the first in-service year of a district heating and cooling system

mean coincident wet-bulb temperature the average temperature recorded on $a$ wet-bulb thermometer at the same time as the design temperature is recorded (see also design temperature) 
multicase steam turbine (see turbine)

national energy-demand region. one of four areas in a gross division of the 48 contignous American states (see map, Fig. D.1)

New Source Performance Standards, status relative to the relationship of a source of airborne emissions to the federal air-quality regulations in effect at the time the emitting facility is constructed

nonwinter final demand requirements for heat during all spring, summer, and fall hours -- including industrial process heat and heat needed for the absorption cooling of large building (see also absorption cooling, large building, and final demand)

onsite fuel fuels consumed at the point where services are needed; for example, natural gas burned in a homeowner's furnace constitutes an onsite fuel, but natural gas burned in an electrical generating plant to provide electricity to the homeowner does not

onsite fuel prices the price of onsite fuel delivered to a consumer (see also onsite fuel)

operation and maintenance costs annually recurring costs of labor and repair to keep mechanical equipment working and to provide for proper administration

peak demand (or instantaneous peak demand) the maximum quantity of energy (electricity or heat) required at any one time

peak thermal capacity total maximum heat supply available within a district heating system

Piqua a small city in Ohio (just north of Dayton); used as an example in the worksheets and sample computer outputs in this report

plant retrofit costs total capital costs incurred in retrofitting an electrical generating plant to serve a district heating network

point source (of pollution) a pollution source that is large, well defined, and stationary (see also area source)

present value value of a future amount of money after it is discounted to "the present" at a specified discount rate

present-worth dollars. same as present value in the DHSM

pre-tax rate of return rate of return before taxes (see also rate of return)

process heat thermal requirements for manufacturing goods; in the model, includes only those demands that may be met by hot water $\left(250^{\circ} \mathrm{F}\right)$ or steam (up to $400 \mathrm{psi}$ ) 
rate of return an input to the model reflecting the cost of capital to construct a district heating and cooling system; for investor-owned utilities, this is the maximum allowable pre-tax rate of return permitted by a regulatory agency; for municipal utilities, it is the cost of new debt (see also pre-tax rate of return)

real discount rate (simplified) the positive or negative difference between a discount rate and an actual inflation rate

real escalation rate annual percentage of increase in the price of a product, computed by using constant dollars; the real escalation rate does not consider the effects of inflation

record one logical grouping of data inputs placed in the DHSM computer model (see also data file)

roplaoomont oxpaity (powor) the amount of clectrical gencrating capacity that must be built to compensate for the derating caused by conversion of electrical generating plants tó district heating and cooling

reserve margin in the model, the quantity of electric or themal power not being used but available for use during peak-demand conditions

residential high density residential buildings characterized by 20 or more dwelling units per structure

residential low density residential buildings characterized by $19^{\circ}$ or fewer dwelling units per structure

residual oil heavy or thick oil. classed by a number of 5 or 6 (see also distillate oil)

retrofit in the model, modification of an existing electrical generating plant or related individual piece of equipment -- tor the purpose of changing the previous application or improving the previous performance of that plant or piece of equipment

savings-to-investment ratio in the DHSM, the relationship of total lifetime avoided fuel expenditures to capital costs of the district heating and cooling system that made the savings possible (see also avoided costs, lifetime costs, capital costs)

scaling factor a multiplier that may be put into the model to change a default value, for the purpose of matching local conditions better or of altering data in a scenario

scenario a hypothetical situation created to test assumptions; in the model, it includes the financial, supply, and service-area assumptions determined by a user

schedule NSPS (New Source Performance Standards)

for an emissions source, a document describing the relationship of source emissions to federal airquality standards 
single-case steam turbine (seeturbine)

space heating delivery of heat to the interior of a building to raise the inside temperature of the spatial volume

station an electrical or thermal generating plant

summer all hours not included in the total heating hours. indicated on the "community demand data sheet"

technical support representative (TSR) staff person at a national laboratory. (Argonne or Oak Ridge) who directly provides communities with technical help in applying national district heating and cooling program

thermal density quantity of heat demanded by or supplied to a given geographic area (expressed in $\mathrm{Btu} / \mathrm{h} . \cdot \mathrm{km}^{2}$ or in $\mathrm{MW} / \mathrm{km}^{2}$ ).

thermal heat rate quantity of heat that may be extracted from a unit over a specified time period

thermal peaking rate quantity of heat that may be extracted from a unit at peak load

thermal peaker a boiler designed only to serve peak heat demands

thermal reserve quantity of heat stored -- or that can be generated using existing equipment -- above what is normally needed at peak demand or over: a period of time

ton (of cooling machine) heat-removal power of $12,000 \mathrm{Btu} / \mathrm{h}$ or $3.52 \mathrm{~kW}$

transmission costs in the hot-water transmission loop assumed by the model, the costs of pipe -- sized for maximum thermal output of a station and laid in a straight line from the station to a service-area boundary -constitute the transmission costs

Lurbine in this report, a machine that takes in combustion gases or steam in order to create mechanical power for an electric generator; principal types of turbines include:

- single-case steam, where steam is passed through the turbine once and then expended;

- multicase steam, where steam is passed through a turbine, expended from it into another turbine, and possibly from the second turbine expended for use in others until the steam loses so much heat that it can no longer economically run a new turbine; and

- cumbustion, which uses natural gas, oil, or other fuel to produce combustion gases that turn the turbine

unit one turbine-generator set in a station or one boiler in a heating plant 
unit capacity (power) the peak power (electric and/or heat) available from a unit

unit code name in the model, a number and letter combination that identifies a unit

unit heat rate the peak amount of heat that can be produced by a unit

unity equal to 1.00

utility AFC rate (see AFC rate)

variable costs operating costs that may be changed from time to time, as opposed to fixed costs that do not change; consist primarily of costs for fuel, operations, and maintenance

year of cash-flow turnaround the first calendar year in which the dullars earned by district heating and cooling system are sufficient to cover all expenses 


\section{APPENDIX B \\ DHSM ABBREVIATIONS \\ AND COMPUTER ACRONYMS*}

AFC

ANL

AREA

ASHE

AWG

B. Bt $\mathrm{u}^{* *}$

Btu or BTU*t;

CAP

CDD

$\mathrm{CDF}$

CDFA

CDMQC

CF or cu. ft.

CHDD

COMM.

$\mathrm{COP}$

CURR \$MIL

DDF

DDFA

DDFAM1

DDFAM2

DDFBC

deg. F or DEG.F

$\mathrm{DH}^{\prime}:$ allowance for funds used during construction

Argonne National Laboratory

area source of airborne emissions

annual space heating energy demand for each building type in each grid square of a community

assessment work group

Btu in billions ( $10^{9}$ Btu)

British therual unit

capacity.

cooling degree-days (annual average)

cost data file

input form title (cost data file - Record A)

climatological dispersion model, version QC

cubic foot or feet $\left(\mathrm{ft}^{3}\right)$

community heating degree-days (annual average)

commercial

coefficient of performance

current dollars in millions $\left(\$ 10^{6}\right)$

demand data file

input form title (demand data file - record $A$ )

input form title (demand data file - record A, map l)

input form title (demand data file - record A, map 2)

input form title (demand data file - records $B$ and $C$ )

degree Fahrenheit $\left({ }^{\circ} \mathrm{F}\right)$

districe heating

*SSome of these depart from standard usage of the modern metric system. They $\because$ have been adopted either for computer purposes or to conform to standard architectural usage.

**The interrelationship between various energy-value. multiples used in the DHSM are shown in a table at the end of this appendix.

$\because \cdot$

$\therefore:$ 


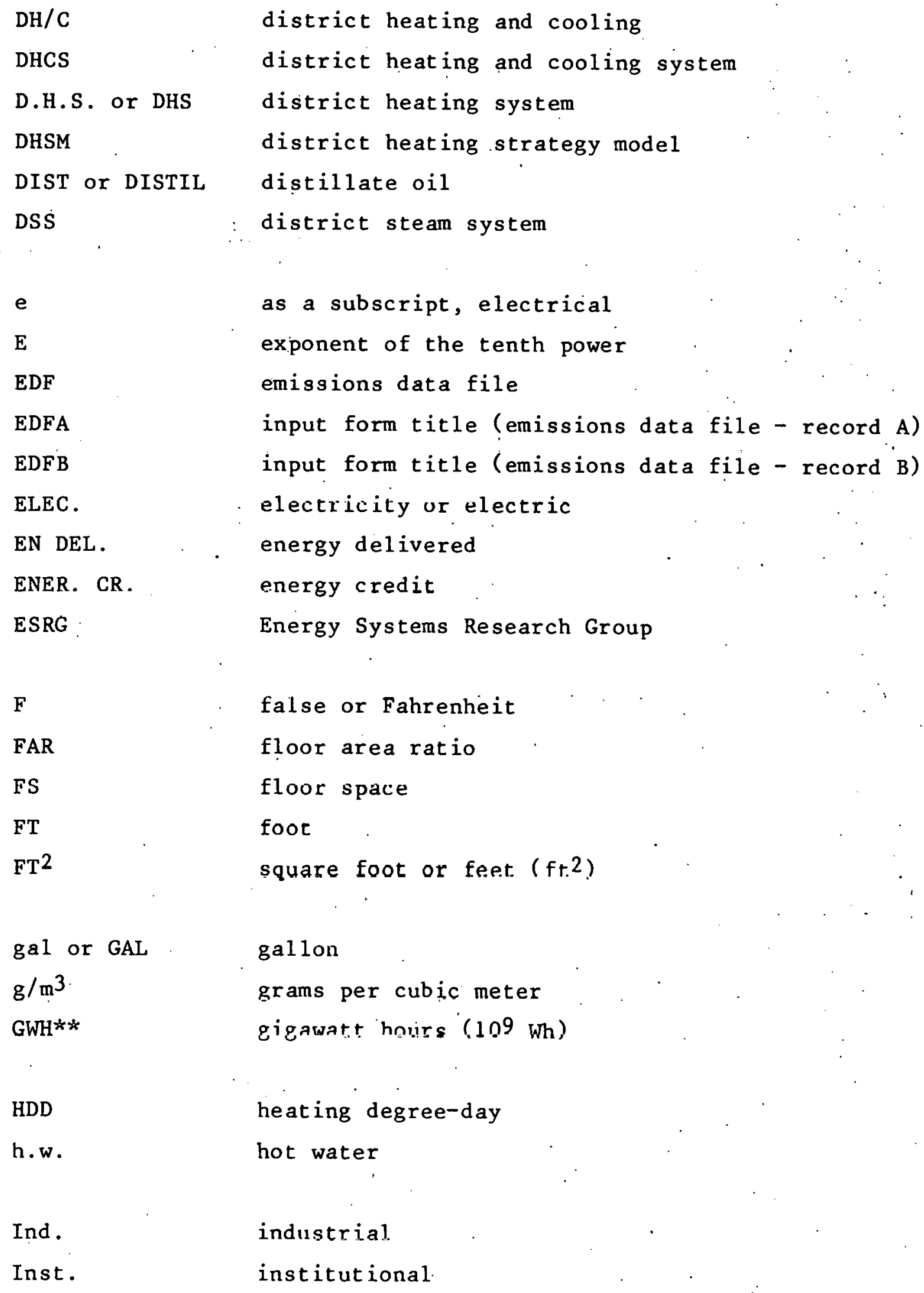


k

K

kgal

km

kWh $*$ *

MBtu**

$\operatorname{mil}$

MISC

MMBt $u^{* x}$.

MIL . CU . FT.

$M W^{* *}$

NEDS

NEWBLBLR

$\mathrm{NO}_{\mathbf{x}}$

N.P.W.

NSPS

NUCL

O\&M

PART.

P.W.

Res .

RES.I

RETRO

RHDD

$\vdots \because \because$

$\because \because$

SDF

SDFA

SDFA.A:I

EDP:

SDFCD: thousand $\left(10^{3}\right)$

a computer term meaning 1024 bytes of memory space

thousand gallons

kilometer

kilowatt-hour

Btu in thousands ( $\left.10^{3} \mathrm{Btu}\right)$

million

miscellaneous

Btu in millions ( $10^{6}$ Btu)

million cubic feet $\left(10^{6} \mathrm{ft}^{3}\right)$

megawatt ( $10^{6}$, or million, watts)

National Emissions Data System

new baseload boiler

nitrogen oxides

net present worth

New Source Performance Standards.

nuclear

operation and maintenance

particulate matter

present worth

residential

residual oil

retrofit

regional heating degree-day (annual average) -- model uses. the following RHDD values, by U.S. region: Northeast, 5400; North Central, 6200; South, 2800; West, 3800 .:

supply data file.

input form ritle (supply data file - record A)

input form title (supply data file - record A, answer. A:

input form title (supply data file - rernor R)

input form title (supply data file - records C. and D) 


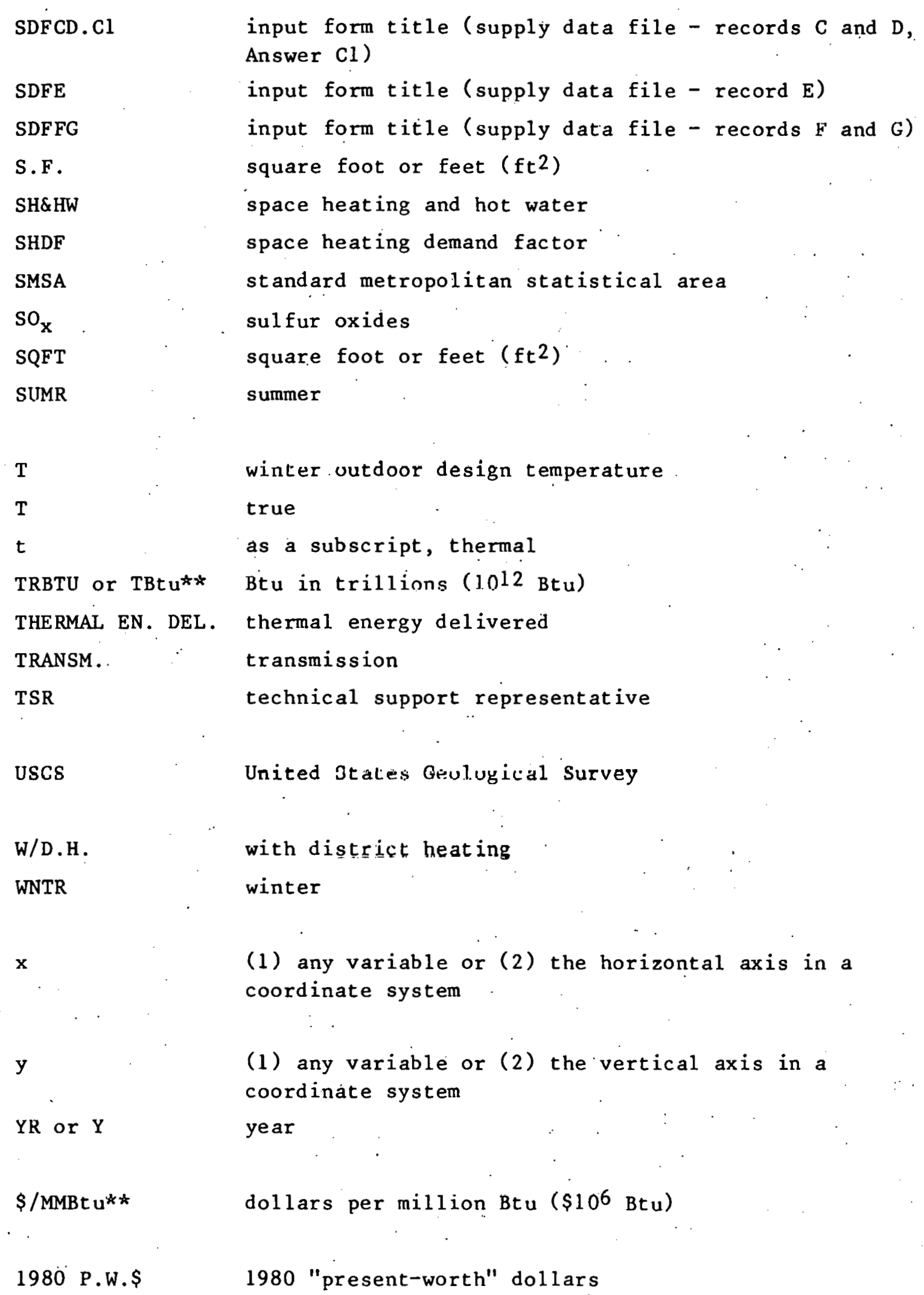


Summary of DHSM Energy-Value Multiples

\begin{tabular}{rrr}
\hline & \multicolumn{2}{c}{ System of Representation } \\
\cline { 2 - 3 } Number of Units & Btu & Watt \\
\hline $1,000\left(10^{3}\right)$ & MBtu & $\mathrm{kW}$ \\
$1,000,000\left(10^{6}\right)$ & MMBtu & $\mathrm{MW}$ \\
$1,000,000,000\left(10^{9}\right)$ & B.Btu & $\mathrm{GW}$ \\
$1,000,000,000,000\left(10^{12}\right)$ & TRBtu & (none used) \\
& TBtu) \\
\hline
\end{tabular}


THIS PAGE

\section{WAS INTENTIONALLY \\ LEFT BLANK}




\section{APPENDIX C \\ COMMON CONVERSIONS BETWEEN ENGLISH \\ AND METRIC MEASURING UNITS, AND \\ HEAT-CONTENT VALUES FOR EIGHT FUELS}

\section{THERMAL-POWER CONVERSIONS}

- thermal power in British thermal units (Btu/h) to thermal power in megawatts (MWt): multiply Btu value 0.2931 . $10^{-6}$

- MWt to Btu: multiply MWt value by $3.414 \cdot 10^{6}$.

- $1 \mathrm{MMBtu} / \mathrm{h}\left(\right.$ or $10^{6}$. Btu/h) $=292.9 \mathrm{~kW}$

TEMPERATURE CONVERSIONS

- Fahrenheit temperature in ${ }^{\circ} \mathrm{F}$ to Celsius temperature in ${ }^{\circ} \mathrm{C}$ : subtract 32 from ${ }^{\circ} F$ value, then multiply by $5 / 9$

- ${ }^{\circ} \mathrm{C}$ to ${ }^{\circ} \mathrm{F}$ : multiply ${ }^{\circ} \mathrm{C}$ value by $9 / 5$, then add 32

- Celsius temperature in ${ }^{\circ} \mathrm{C}$ to kelvin temperature in $\mathrm{K}$ : add 273.16 to ${ }^{\circ} \mathrm{C}$ value

- K to ${ }^{\circ} \mathrm{C}$ : subtract 273.16 from $\mathrm{K}$ value

LENGTH CONVERSIONS

- 1 foot $(\mathrm{ft})=0.3048 \operatorname{meter}(\mathrm{m})$

- $1 \mathrm{~m}=3.281 \mathrm{ft}$

- 1 mile $(\mathrm{mi})=1.609 \mathrm{kilometers}(\mathrm{km})$

- $1 \mathrm{~km}=0.6215 \mathrm{mi}$

AREA CONVERSIONS

- 1 square mile $\left(\mathrm{mi}^{2}\right)=2.590$ square kilometers $\left(\mathrm{km}^{2}\right)$

- $1 \mathrm{~km}^{2}=0.3861 \mathrm{mi}^{2}$

- 1 acre $=0.004046 \mathrm{~km}^{2}$

- $1 \mathrm{~km}^{2}=247.1$ acres 
HEAT-CONTENT VALUES FOR EIGHT FUELS

- Natural gas - $1,016 \mathrm{Btu} / \mathrm{ft}^{3}$ or $100,000 \mathrm{Btu} /$ therm

- Distillate oil ${ }^{\dagger}$ - $138,690 \mathrm{Btu} / \mathrm{gal}$

- Residual oil ${ }^{\dagger} \quad$ - $149,690 \mathrm{Btu} / \mathrm{gal}$

- Anthracite coal - $25.2 \mathrm{MMBtu} /$ ton

- Electricity - $\quad 3,412 \mathrm{Btu} / \mathrm{kWh}$

- Steam - $1,000 \mathrm{Btu} / 1 \mathrm{~b}$

- $200^{\circ} \mathrm{F}$ hot water - $1 \mathrm{Btu} / \mathrm{lb}$ per degree of temperature drop

- Average refuse - 4,500 to $5,000 \mathrm{Btu} / \mathrm{lb}$ 


\begin{abstract}
APPENDIX D
DHSM DEFAULT DATA, ECONOMIC-ANALYSIS TECHNIQUES, AND PIPING-COST EQUATIONS
\end{abstract}

\title{
D.1 DEFAULT DATA
}

Unless modified by the user, the data listed in this appendix are processed by the DHSM in its calculations. They are listed here to familiarize community planners with the demand and cost assumptions, or default ${ }^{\dagger}$ values, programmed into the computer model in lieu of more community-specific data -- and also, where appropriate, to encourage replacement of these 1 isted default values.

\section{D.1.l Annual Energy-Demand Factors}

The formula used within the demand module to calculate annual energy demands is:

$$
\mathrm{ASHE}=\mathrm{SHDF} \cdot \mathrm{FS} \cdot \frac{\mathrm{CHDD}}{\mathrm{RHDD}}
$$

where:

$$
\begin{aligned}
\text { ASHE }= & \text { annual space-heating energy demand for each } \\
& \text { building type in each grid square, } \\
\text { SHDF = } & \text { space-heating demand factor, } \\
\text { FS }= & \text { total floor space for each building type in } \\
& \text { each grid, } \\
\text { CHDD = } & \text { annual average of community heating degree-days, } \\
\text { RHDD = } & \text { and } \\
& \text { p. } 29 \text { of this report for RHD values used in model. }
\end{aligned}
$$

Default values for space-heating demands are shown in 'lable D.1. The user can replace these values either for individual grid squares or for the entire city. The table also lists default values for water-heating factors. Water-heating demands for each building type in each grid square are computed by multiplying the total floor space of the building type in the grid square by the appropriate demand value.

Peak daily space-heating demands are computed by multiplying the annual space-heating demands by $(65-T) / C H D D$, where $T$ is the winter outdoor design temperature in $F$. Peak daily water-heating demands are computed by dividing the annual water-heating thermal demands by 365 .

\section{1.2 Fuel-Efficiency Data}

$\therefore$ The assumed fuel efficiencies for space heating, space cooling, water heating, and heat for industrial processes are shown in Table D.3. Adjustments to these factors can be made in the input to the emissions module. $\because \therefore$ 


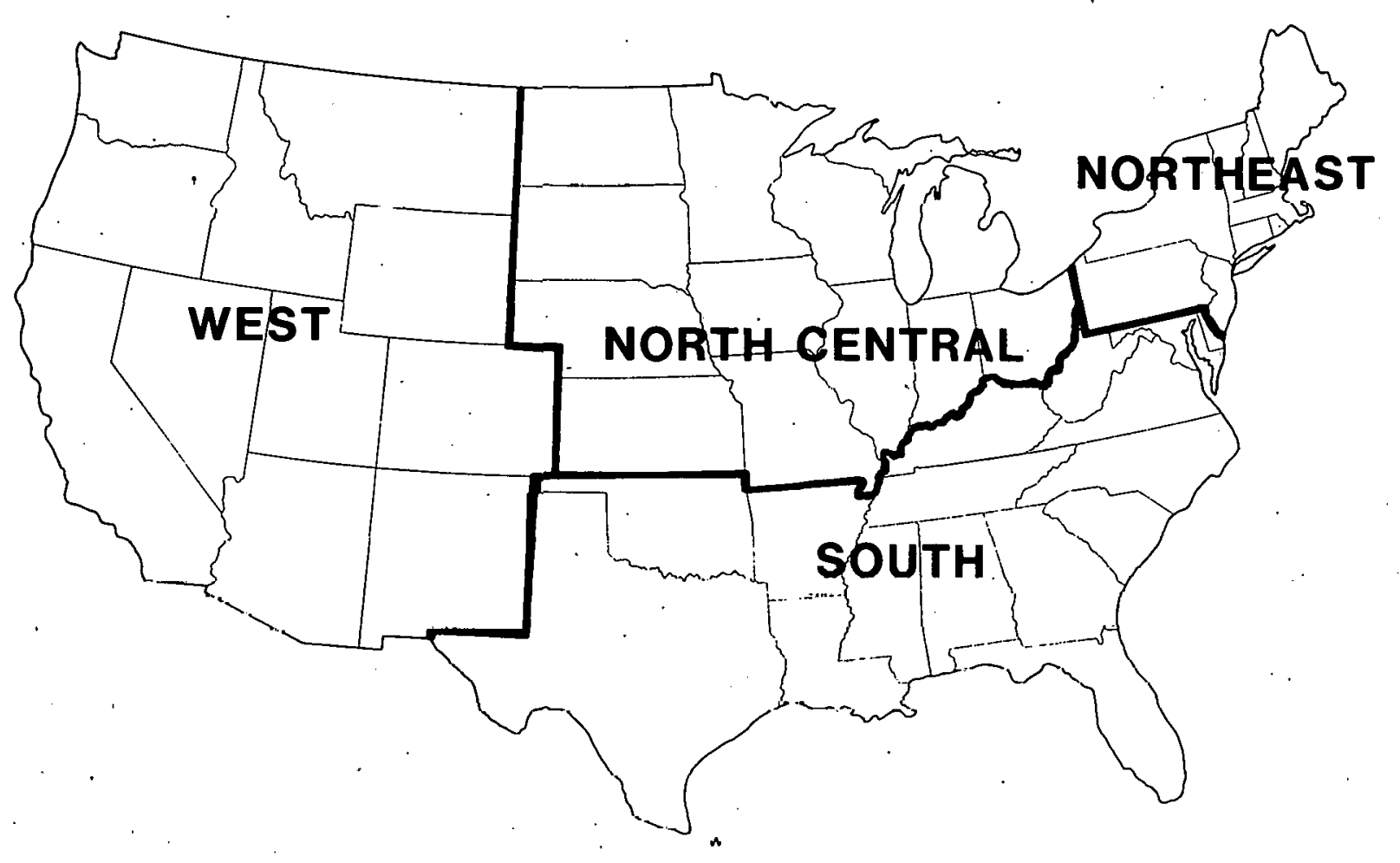

Fig. D.1 National Energy-Demand Regions

\section{1.3 Cost Factors}

Table D.4 lists electricity-replacement costs, $\dagger$ and Table D.5 1ists the low and high factors used in the district heating strategy model to estimate capital and operating and maintenance costs. Whether the low or the high factors are used is decided by the program user.

The DHSM does not currently have the capability of processing rost factors that may have been adjusted for an individual community. However, because all cost factors are expressed in 1980 dollars - and because the user must therefore specify escalation-ratet inputs to the program for capital, $O \& M$, and fuel costs -- there is a way of indirectly compensating for cost factors that need adjustment. If the DHSM user knows that certain DHSM cost factors are not appropriate to, the specific district heating and cooling system under consideration, escalation rates can be used to increase or decrease total capital or total O\&M costs to reflect these differences. The ANL staff will make appropriate adjustments in the escalation rates to correspond to other district heating and cooling cost estimates community planners may wish to use.

\section{D.2 INTRODUCTION TO DHSM GENERAL COST-ANALYSIS TECHNIQUES}

The economic analysis performed by DHSM is based on estimating $a$. chronological sequence of dollar-value benefits - in terms of energy saved, avoided costs ${ }^{\dagger}$, and district heating and cooling costs (construction, operation, and maintenance), generated over the life of a proposed system. Each 
Table D.1 Default Values. Used in the DHSM to Calculate Annual Energy Demands - by Fuel - for Space and Water Heating.

\begin{tabular}{|c|c|c|c|c|c|c|}
\hline \multirow[b]{2}{*}{$\begin{array}{l}\text { U.S. Region a and } \\
\text { Building Type }\end{array}$} & \multicolumn{2}{|c|}{ Annual } & ace $\mathrm{He}$ & ing $\left(10^{3}\right.$ & $\left.\mathrm{Btu} / \mathrm{ft}^{2}\right)$ & $\begin{array}{c}\text { Annual } \\
\text { Water Heating } \\
\left(10^{6} \mathrm{Btu} / \mathrm{ft}^{2}\right)\end{array}$ \\
\hline & Gas & oil & Coal & $\begin{array}{l}\text { Elec- } \\
\text { tricity }\end{array}$ & $\begin{array}{c}\text { District } \\
\text { Steam }\end{array}$ & $\frac{(10 \mathrm{Btu} / \mathrm{tt})}{\text { Al1 Fuels }}$ \\
\hline \multicolumn{7}{|l|}{ Northeast } \\
\hline $\begin{array}{l}\text { Res. low density } \\
\text { Res. high density } \\
\text { Com./inst. } \\
\text { Industrial } \\
\text { North Central }\end{array}$ & $\begin{array}{l}61 \\
48 \\
71 \\
49\end{array}$ & $\begin{array}{l}81 \\
64 \\
66 \\
45\end{array}$ & $\begin{array}{l}70 \\
69 \\
75 \\
51\end{array}$ & $\begin{array}{l}30 \\
19 \\
24 \\
16\end{array}$ & $\begin{array}{l}63 \\
63 \\
63 \\
63\end{array}$ & $\begin{array}{l}14 \\
14 \\
3.6 \\
2\end{array}$ \\
\hline $\begin{array}{l}\text { Res. low density } \\
\text { Res. high density } \\
\text { Com./inst. } \\
\text { Industrial }\end{array}$ & $\begin{array}{l}79 \\
45 \\
66 \\
46\end{array}$ & $\begin{array}{l}76 \\
45 \\
53 \\
37\end{array}$ & $\begin{array}{l}78 \\
45 \\
65 \\
45\end{array}$ & $\begin{array}{l}41 \\
22 \\
19 \\
13\end{array}$ & $\begin{array}{l}73 \\
73 \\
73 \\
73\end{array}$ & $\begin{array}{c}14 \\
14 \\
3.6 \\
2\end{array}$ \\
\hline \multicolumn{7}{|l|}{ South } \\
\hline $\begin{array}{l}\text { Res. low density } \\
\text { Res. high density } \\
\text { Com./inst. } \\
\text { Industrial }\end{array}$ & $\begin{array}{l}27 \\
18 \\
45 \\
27\end{array}$ & $\begin{array}{l}49 \\
32 \\
49 \\
24\end{array}$ & $\begin{array}{l}36 \\
24 \\
47 \\
28\end{array}$ & $\begin{array}{l}19 \\
11 \\
15 \\
11\end{array}$ & $\begin{array}{l}32 \\
32 \\
32 \\
32\end{array}$ & $\begin{array}{l}14 \\
14 \\
3.6 \\
2\end{array}$ \\
\hline \multicolumn{7}{|l|}{ West } \\
\hline $\begin{array}{l}\text { Res. low density } \\
\text { Res. high density } \\
\text { Com./inst. } \\
\text { Industrial }\end{array}$ & $\begin{array}{l}32 \\
24 \\
51 \\
33\end{array}$ & $\begin{array}{l}59 \\
39 \\
46 \\
30\end{array}$ & $\begin{array}{l}45 \\
29 \\
53 \\
34\end{array}$ & $\begin{array}{l}27 \\
16 \\
17 \\
13\end{array}$ & $\begin{array}{l}40 \\
40 \\
40 \\
40\end{array}$ & $\begin{array}{c}14 \\
14 \\
3.6 \\
2\end{array}$ \\
\hline
\end{tabular}

a National energy-demand regions are shown in Fig. D.1.

Table D.2 DHSM Default Values for Cooling Large Buildings ${ }^{a}$

\begin{tabular}{lc}
\hline \multicolumn{1}{c}{ Regionb } & $\begin{array}{c}\text { Annual Cooling Default } \\
\text { Values, All Fuels } \\
\left(13^{3} \text { Btu/ft }{ }^{2}\right)\end{array}$ \\
\hline Northeast & 33 \\
North Central & 36 \\
South & 87 \\
West & 57 \\
\hline
\end{tabular}

${ }^{a_{E x c l u s i v e}}$ of equipment inefficiencies.

$b_{\text {National energy-demand regions shown }}$ in Fig. D.l. 
Table D.3 Mean Annual Fuel Efficiencies ${ }^{\dagger}$ by. Building Type and End Use of Energy

\begin{tabular}{|c|c|c|c|c|c|c|}
\hline \multirow[b]{2}{*}{ Building Type } & \multirow[b]{2}{*}{ End Use } & \multicolumn{5}{|c|}{ Fue1 } \\
\hline & & Gas & oil & Coal & $\begin{array}{c}\text { Elec- } \\
\text { tricitya }\end{array}$ & $\begin{array}{l}\text { District } \\
\text { steamb }\end{array}$ \\
\hline $\begin{array}{l}\text { Res. low } \\
\text { density }\end{array}$ & $\begin{array}{l}\text { Space and } \\
\text { water heating }\end{array}$ & 0.6 & 0.5 & 0.5 & 0.3 & 0.64 \\
\hline $\begin{array}{l}\text { Res. high } \\
\text { density }\end{array}$ & $\begin{array}{l}\text { Space and } \\
\text { water heating }\end{array}$ & 0.6 & 0.5 & 0.5 & 0.3 & 0.64 \\
\hline Com./inst: & $\begin{array}{l}\text { Space and } \\
\text { water heating }\end{array}$ & 0.6 & 0.5 & 0.5 & 0.3 & 0.64 \\
\hline Industrial & $\begin{array}{l}3 \text { paice did } \\
\text { water heating }\end{array}$ & 0.6 & 0.5 & 0.5 & 0.3 & 0.64 \\
\hline Large building & Cooling & - & - & - & 0.62 & 0.43 \\
\hline Industrial & Process heat & 0.6 & 0.5 & 0.5 & 0.3 & 0.64 \\
\hline
\end{tabular}

Assumes $33 \%$ generation efficiency and $90 \%$ transmission/distribution efficiency. For cooling, a value of 2.1 is assumed for the coefficient of performance.

${ }^{b}$ Assumes $78 \%$ thermal generation efficiency and $82 \%$ transmission/distribution efficiency. For cooling, a value 0.67 is assumed for the absorption chiller's coefficient of performance.

Table D.4 Costs of Retrofit ${ }^{\dagger}$ and Electricity Replacement by Type of Genorating Unit

\begin{tabular}{|c|c|c|c|c|}
\hline \multirow{2}{*}{ Unit Type } & \multicolumn{2}{|c|}{$\begin{array}{c}\text { Retrofit Costs } \\
(\$ / \mathrm{kW})\end{array}$} & \multicolumn{2}{|c|}{$\begin{array}{c}\text { Replacement Costs } \\
(\$ / \mathrm{kW}) \\
\end{array}$} \\
\hline & Low & High & Low & $\mathrm{High}$ \\
\hline Single-case steam turbine & 41.85 & 83.70 & 314 & 628 \\
\hline Multicase steam turbine & 20.95 & 41.90 & 314 & 628 \\
\hline Combustion turbine & $13: 20$ & 26.40 & 314 & 628 \\
\hline Boiler & 4.50 & 9.00 & $\mathrm{~N} / \mathrm{A}$ & $\mathrm{N} / \mathrm{A}$ \\
\hline
\end{tabular}


Table D.5 Default Factors Used in the DHSM to Calculate Capital and O\&M Costs of System Components

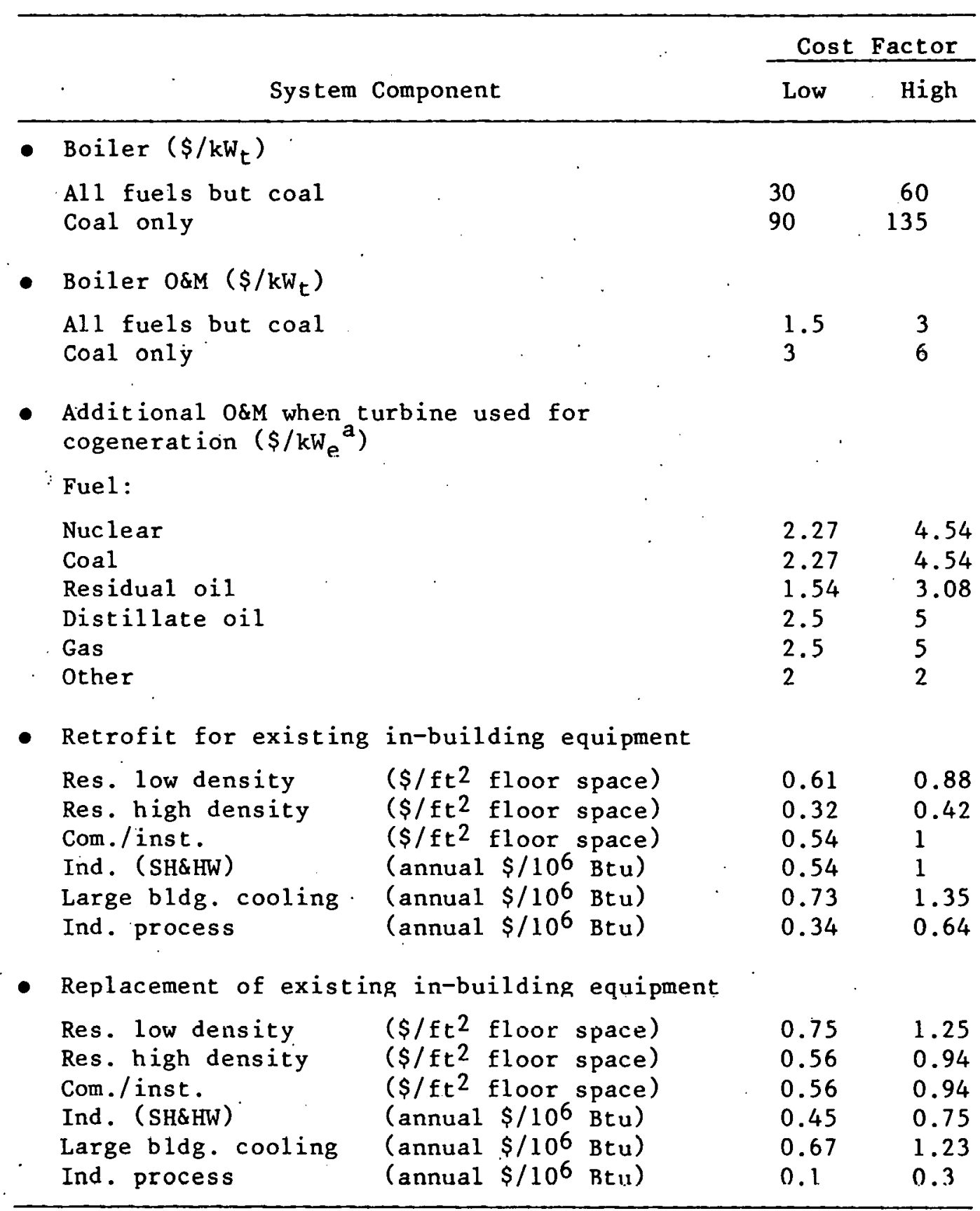

\footnotetext{
(original electric capacity, in MW) (cogen-

$a_{\text {Units in }} \mathrm{kWh}_{e}=\frac{\text { erated annual thermal production, in } \mathrm{kWh}_{\mathrm{t}} \text { ) }}{\text { (cogenerated thermal capacity, in } \mathrm{MW} \text { ) }}$
} 
configuration is then evaluated by calculating its economic benefits over time in terms of present dollars; appropriate user-specified "discount" factors are used, and the system is compared economically to other options and ranked according to its economic merit. This section describes the economic analysis procedure used in DHSM.

\section{D.2.1 Definitions}

Elements used in the economic-analysis procedure are symbolized and defined as follows.

$a=$ allowance for interest on funds used during construction, or AFC ${ }^{\dagger}$ rate (with compounding assumed). Two procedures are common: (1) "normalized" and (2) "flowthrough." If the normalized procedure is used; " $a$ ". is Lypically the afcer-rax embedded (historical or average) cost of capital. If the flow-through procedure is used, the pre-tax embedded cost of capital is usually applied.

$r=$ allowed rate of return ${ }^{\dagger}$ on capital. Typically, this amounts to the pre-tax marginal rate of return plus an allowance for insurance and property taxes.

$d=$ real discount rate. ${ }^{\dagger}$ Typically, this is the rate above inflation used to express the time value of money, or the after-tax marginal rate of return.

$i=$ inflation rate.

$t=$ year index .

$e_{c}=$ real escalation rate ${ }^{\dagger}$ for capital costs.

$e_{f}=$ real escalation rate of costs for fuel type $f$.

$e_{O M}=$ real escalation rate of operating and maintenance costs.

$\mathrm{C}=$ capital costs.

$F=$ fuel cost.

$\mathrm{OM}=$ operating and maintenance cost.

$\mathrm{P}_{\mathrm{C}}=$ present value ${ }^{\dagger}$ of costs, assuming 1980 as the base year.

$\mathrm{T}_{\mathrm{C}}=$ year construction starts.

$\mathrm{T}_{\mathrm{S}}=$ year service starts.

$\mathrm{T}_{\mathrm{LT}}=$ Litetime of system.

$\mathrm{T}_{\mathrm{CR}}=$ capital-recovery period.

$F C=$ annual fixed charge rate on total invested capital. This converts the stream of capital charge stream into a uniform series of costs over.the capital-recovery period. ${ }^{\dagger}$ 


\section{D.2.2 Cost Calculations for a District System}

If capital costs are assumed to be incurred at a uniform annual rate $\left(C_{o}\right)$ during the construction period $\left(\mathrm{T}_{\mathrm{S}}-\mathrm{T}_{\mathrm{C}}\right)$ of a proposed system, then the total capital cost $\left(\mathrm{C}_{\mathrm{T}_{\mathrm{S}}}\right)$ incurred up to the year service starts ( $\left.\mathrm{T}_{\mathrm{S}}\right)$ is expressed:

$$
\mathrm{C}_{\mathrm{T}_{\mathrm{S}}}=\sum_{\mathrm{t}=\mathrm{T}_{\mathrm{C}}}^{\mathrm{T}_{\mathrm{S}}-\mathrm{l}} \mathrm{C}_{\mathrm{O}} \cdot\left(1+i+\mathrm{e}_{\mathrm{C}}\right)^{(\mathrm{t}-1980)} \cdot(1+\mathrm{a})^{\left(\mathrm{T}_{\mathrm{S}}-\mathrm{t}\right)} \ldots
$$

where 1980 is the assumed base year for all cost estimates and present value calculations. This expresssion escalates each year's construction expenditure, $C_{O}$, to, $T_{S}$ at the rate of $\left(i+e_{c}\right)--$ and compounds interest expenses incurred at rate a.

In each subsequent in-service year, the allowed annual capital charges, $C_{t}$, assuming straight-1ine depreciation, are expressed:

$$
\begin{aligned}
c_{t}=r \cdot C_{T_{S}} \cdot \frac{1-\left(t-T_{S}\right)}{T_{C R}}+\frac{C_{T_{S}}}{T_{C R}} \\
\quad \text { for } t=T_{S}, T_{S}+1, \ldots T_{S}+T_{C R}-1
\end{aligned}
$$

The first term in this expression is the allowed rate on undepreciated capital, and the second term is the (straight line) depreciation charge.

The present worth of this stream of costs in 1980 dollars is expressed:

$$
\mathrm{P}_{\mathrm{C}}=\sum_{\mathrm{t}=\mathrm{T}_{\mathrm{S}}}^{\mathrm{T}_{\mathrm{S}}+\mathrm{T}_{\mathrm{CR}}-1} \frac{\mathrm{C}_{\mathrm{t}}}{(1+\mathrm{i}+\mathrm{d})^{\mathrm{t}}}
$$
An annual fixed charge rate, $\mathrm{FC}$, on total invested capital, $\mathrm{C}_{\mathrm{T}} \mathrm{S}_{\text {, }}$
makes this stream uniform. This action is expressed:

$$
\mathrm{P}_{\mathrm{C}}=\sum_{\mathrm{t}=\mathrm{T}_{\mathrm{S}}}^{\mathrm{T}_{\mathrm{S}}+\mathrm{T}_{\mathrm{CR}}-1} \frac{\mathrm{FC} \cdot \mathrm{C}_{\mathrm{T}_{\mathrm{S}}}}{(1+\mathrm{i}+\mathrm{d})^{\mathrm{t}}} \text { for } \mathrm{FC} .
$$

Therefore, Eqs. D. 3 and D.4 can be used to solve for FC:

$$
\begin{gathered}
\mathrm{FC}=\mathrm{r}+\frac{1}{\mathrm{~T}_{\mathrm{CR}}} \cdot\left[1-\mathrm{r}\left(\frac{\mathrm{q}}{(1-\mathrm{q})}-\frac{\mathrm{T}_{\mathrm{CR}} \cdot \mathrm{q}^{\mathrm{T}} \mathrm{CR}}{\left(1-\mathrm{q} \mathrm{T}_{\mathrm{CR}}\right)}\right)\right] \\
\text { if } \mathrm{q}=\frac{1}{(\mathrm{i}+\mathrm{i}+\mathrm{d})} \neq 1, .
\end{gathered}
$$


or, alternatively,

$$
\begin{gathered}
\mathrm{FC}=\mathrm{r} \cdot\left[1-\frac{\mathrm{T}_{\mathrm{CR}}-1}{2 \mathrm{~T}_{\mathrm{CR}}}\right]+\frac{1}{\mathrm{~T}_{\mathrm{CR}}} \\
\quad \text { if } \mathrm{q}=1 .
\end{gathered}
$$

The average annual present value of capital costs over the system lifetime (TLT) is then expressed:

$$
\overline{\mathrm{P}}_{\mathrm{C}}=\frac{1}{\mathrm{~T}_{\mathrm{LT}}} \sum_{\mathrm{t}=\mathrm{T}_{\mathrm{S}}}^{\mathrm{T}_{\mathrm{S}}+\mathrm{T}_{\mathrm{CR}}-1} \frac{\mathrm{FC} \cdot \mathrm{C}_{\mathrm{T}}}{(1+\mathrm{i}+\mathrm{d})(\mathrm{t}-1980)}
$$

Similarly, the average annual present value of fuel costs and operating and maintenance costs are expressed:

$$
\bar{P}_{f}=\frac{1}{T_{L T}} \sum_{t=T_{S}}^{T_{S}+T_{L T}-1} \frac{F_{f} \times\left(1+i+e_{f}\right)^{(t-1980)}}{(1+i+d)^{(t-1980)}},
$$

and

$$
\bar{P}_{\mathrm{OM}}=\frac{1}{\mathrm{~T}_{\mathrm{LT}}} \sum_{t=\mathrm{T}_{\mathrm{S}}}^{\mathrm{T}_{\mathrm{S}}+\mathrm{T}_{\mathrm{LT}}-1}, \frac{\mathrm{OM} \times\left(1+i+e_{\mathrm{OM}}\right)(\mathrm{t} \cdot 1900)}{(1+i+d)(t-1980)},
$$

respect ively.

Finally the annual average of present-value costs is expressed:

$$
\bar{P}_{C}=\bar{P}_{c}+\bar{P}_{f}+\bar{P}_{(M M}
$$

\section{D.2.3 Procedure for Configuring a District System}

The DHSM uses the above cost analysis to calculate the annual average of present-value costs to deliver energy from each plant to the edge of the user-specified service areas. In selecting and ranking thermal-energy plants, and thus configuring a district heating and cooling system, the DHSM follows the procedure outlined below.

- Calculates various demands for thermal energy, geographically and according to energy end uses by building type, for the scenario being evaluated. 
- Calculates operating characteristics of each new or retrofitted turbine and heat-only boiler in a user-specified list of supply options. The options can include cogenerated thermal capacity, electrical capacity derating (if any), base fuel use, system fuel use for district heating and cooling, and thermal energy delivered to the service area.

- Calculates each element of annualized cost for each unit delivering energy to a service area. These include costs for plant construction and/or retrofit, replacement of derated electrical capacity (if any), and plant O\&M for either a specified "low-cost" or "high-cost" scenario.

- Aggregates new and retrofitted units, by operating characteristics and annual costs, into groups of units (turbines, boilers) using the same fuel at the same station (station fuel groups); sizes a transmission pipe to the maximum thermal output of each station fuel group; finds the length of that pipe to the nearest point of the service area; and calculates the annualized capital cost of that transmission pipe. It also calculates annual $0 \& M$ costs for the transmission equipment.

- Calculates escalation and interest during construction, and average annual present-worth factors on the basis of financial assumptions.

- Computes total average of annual costs per $10^{6}$ Btu delivered, discounted to 1980 present-worth dollars over the life of the district heating system for each station fuel group. Also finds the thermal capacity and annual delivered thermal energy from each station fuel group.

- Ranks each station fuel group according to the average annual (discounted) costs per $106 \mathrm{Btu}$ thermal energy delivered.

- Chooses the lowest-cost set of these station fuel groups as the thermal supply system -- consistent with providing sufficient thermal energy and peak capacity for the service area, and consistent'with a user-specified cost ceiling.

- Assumes that a new baseload heat-only boiler unit is built if sufficient thermal energy supply is otherwise unavailable (at or below ceiling cost). The DHSM then calculates the contribution of the new boiler to the cost of delivering thermal energy within the service area.

- Assigns additional peaking capacity to the system if necessary. This step is taken if the units previously selected to meet an area's thermal demands cannot also provide sufficient thermal capacity to meet peak winter thermal demands (including a user-specified reserve). The capacity thus assigned can come from either of two sources: (1) available capacity from existing thermal-only units that have not been selected to provide thernal energy (in order of their cost per $\mathrm{kW}$ ); and (2) assumed construction of a heat-only boiler to be used for peaking. 


\section{D.2.4 Procedure for Analyzing Savings-to-Investment Ratio ${ }^{\dagger}$}

The above procedure allows the model to configure a district heating and cooling system to meet user-specified needs at a minimum annual cost. However, these costs are calculated only for a service area. After the system has been configured, the model performs a savings-to-investment analysis that compares the. life-cycle costs of the district system against those of conventional systems -- as follows.

- Calculates the component cost of thermal-1oop transmission, distribution, and building end-use retrofit costs in the service areas -- and adds these capital costs to those already calculated to configure the system.

- Calculates building fuel use and fuel costs by sector before and after a district heating system is in operation, and calculates costs avoided by employing the system.

- Analyzes cash flow, net benefits, savings-to-investmentratio, discounced payback period; determines the year of cash flow turnaround (i.e., community's breakeven year).

\section{D.3 INTRODUCTION TO DHSM TRANSMISSION AND DISTRIBUTION COST-ANALYSIS TECHNIQUES}

The transmission and distribution costs of a district system are computed using various engineering conventions as well as the results of district heating and cooling research conducted previously. The parameters and equations used in the DHSM for this specific area of cost analysis follow.

\section{D.3.1 Definitions}

Elements used in this cost-analys is procedure are symbolized and defined as follows.

$\mathrm{E}$ - final service area energy demand in $10^{9} \mathrm{Btu}$.

A - service area in $\mathrm{km}^{2}$.

$r_{1}$ - ratio of final energy demand to end-use thermal demand in a district heating system.

$r_{2}$ - ratio of nonwinter to winter thermal demand.

d - transmission line diameter in inches.

1 - transmission line length in feet.

$C_{D}$ - distribution piping costs in millions of 1980 dollars.

$\mathrm{C}_{\mathrm{I}}$ - transmission-loop piping costs in millions of 1980 dollars.

$\mathrm{C}_{\mathrm{T}}$ - transmission-1ine piping costs in millions of 1980 dollars.

$P$ - peak thermal power in MW. 
c - coefficient plugged into a cost equation (taken from the table following the equations below).

$k$ - variable used to describe the number of transmission pipes required for handling a given peak of thermal power.

\section{D.3.2 DHSM Piping-Cost Calculations}

The DHSM calculates separate costs for distribution piping, a transmission loop, and transmission lines.

Distribution Piping Costs

$$
\begin{aligned}
& \mathrm{C}_{D}=c^{D_{1}} \cdot A+c^{D_{2}} \frac{E}{1000} \frac{1}{r_{1}\left(r_{2}+1\right)} \\
& c^{D_{1}}=\begin{array}{r}
4.0 \text { for high-cost scenario, or } \\
1.4 \text { for a low-cost scenario }
\end{array} \\
& c^{D_{2}}=\begin{array}{r}
20.5 \text { for a high-cost scenario, or } \\
7.2 \text { for a low-cost scenario }
\end{array} \\
& \text { O\&M costs }=0.01 \cdot C_{D}
\end{aligned}
$$

\section{Transmission-Loop Piping Costs}

$$
\begin{aligned}
& C_{L}=c^{L}{ }_{o} \cdot\left(A \cdot c^{L} 1+c^{L} \frac{E}{1000} \frac{1}{r_{1}\left(1+r_{2}\right)}\right) \\
& c^{L_{o}}=\begin{array}{l}
1.0 \text { for a high-cost scenario, or } \\
0.35 \text {. for a low-coet ecenario }
\end{array} \\
& \mathrm{cL}_{1}=1.96 \\
& \mathrm{cL}_{2}=9.21 \\
& \text { O\&M costs }=0.01 \cdot \mathrm{C}_{\mathrm{L}} \text {. }
\end{aligned}
$$

\section{Transmission-Line Piping Costs}

Piping costs depend on peak thermal power.

If $P \leq 581 \mathrm{MW}$, then a single-pipe transmission Iine is used $(k=1)$.

If $581 \mathrm{MW}<\mathrm{P} \leq 1743 \mathrm{MW}$, then a dual pipe transmission line is used $(k=2)$. 
If $P>1743 \mathrm{MW}$, then a triple-pipe transmission line is used $(k=3)$.

$\mathrm{d}=2.2 \cdot(\mathrm{P} / \mathrm{k})^{1 / 2}$

If $\mathrm{d}>24^{\prime \prime}$, diameter is rounded to the nearest $6 "$-diameter size.

$\mathrm{C}_{\mathrm{T}}=\mathrm{k} \cdot \frac{1}{10^{6}} \cdot\left(\mathrm{c}^{\mathrm{T}} \mathrm{l(k)}+\mathrm{c}_{2(\mathrm{k})} \cdot \mathrm{d}\right)$

O\&M cost $=0.01 \cdot \mathrm{C}_{\mathrm{T}}$

Table D.6 Transmission Cost Coefficients (vimensionless)

\begin{tabular}{|c|c|c|c|c|c|}
\hline \multirow{2}{*}{\multicolumn{2}{|c|}{$\begin{array}{l}\text { No. of } \\
\text { Pipes Needed }\end{array}$}} & \multicolumn{2}{|c|}{$\begin{array}{ll} & c^{\mathrm{T}} 1(k) \\
\text { Cost } & \text { Coefficient } \\
\end{array}$} & \multicolumn{2}{|c|}{$\begin{array}{ll} & c^{\mathrm{T}} 2(\mathrm{k}) \\
\text { Cost Coefficient } \\
\end{array}$} \\
\hline & & Low & . High & Low & High \\
\hline $\mathrm{K}$ & $x=1$ & 121.26 & 173.23 & 9.42 & 13.45 \\
\hline $\mathrm{K}$ & $k=2$ & 22.61 & 32.3 & 12.71 & 18.15 \\
\hline $\mathbf{K}$ & $x=3$ & -246.5 & -352.13 & 20.18 & 28.83 \\
\hline
\end{tabular}




\section{APPENDIX E \\ PREPARATION OF DATA-INPUT WORKSHEETS}

\section{E. 1 OVERVIEW}

This section describes and illustrates the several different worksheet forms used by community analysts for specifying the DHSM input data.

For convenience and orderliness of preparation, each data-input sheet has been designated in one of four ways: demand, supply, cost, or emissions. A large capital letter in the upper right corner (D, S, C, E.) graphically signifies a sheet's designation. Figure E.l shows the sequence in which the worksheet packages are prepared - starting with the demand file in the foreground of the illustration and working back to the emissions file. The figure also indicates that the four data files contain a total of nine different types of forms. Some of the demand and supply forms need to be completed in multiple copies; one of the supply forms has two parts; and another supply form is an optional one, which may or may not need to be completed depending upon a community's objectives.

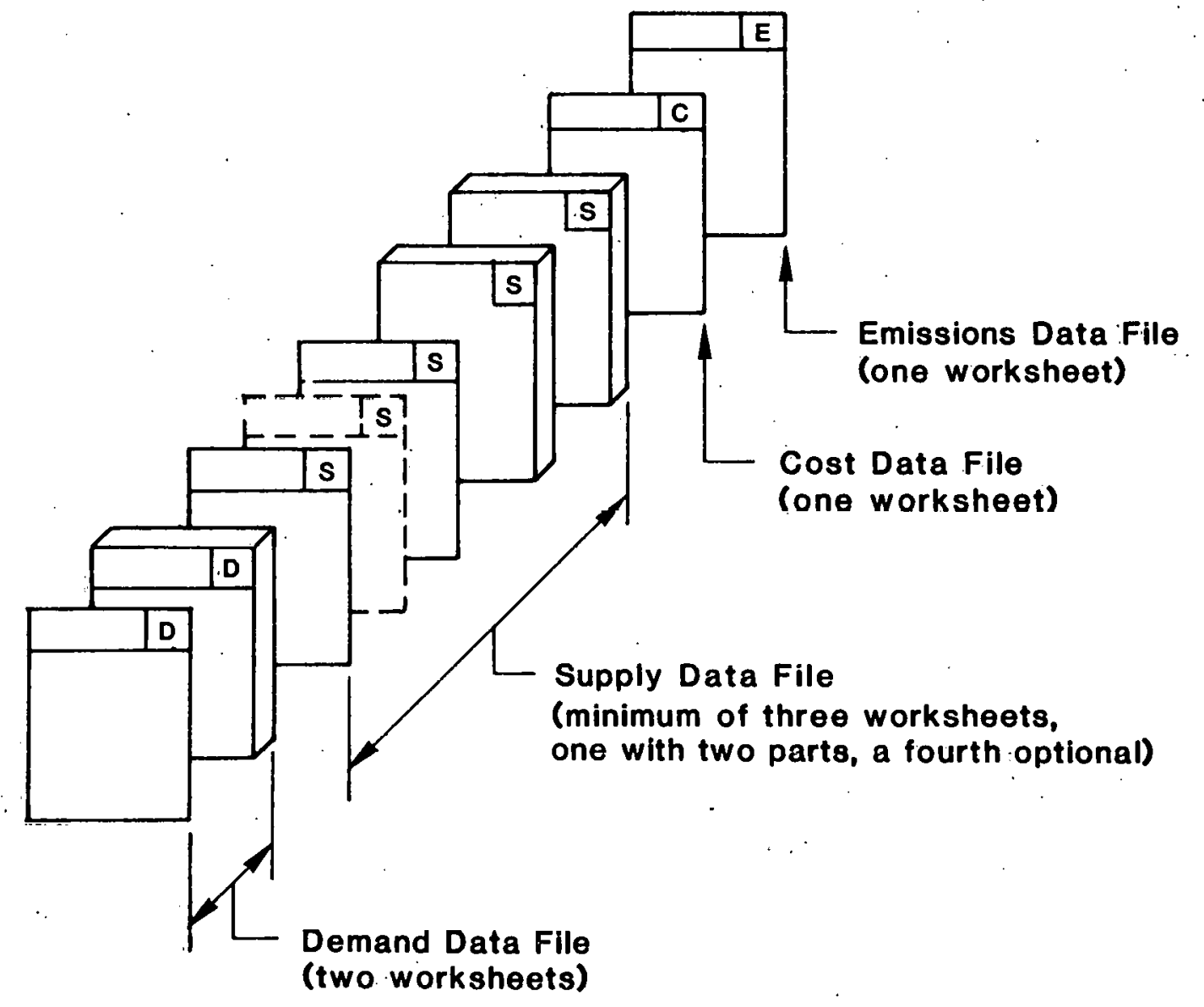

Fig. E.1 Data=Input Packages in Order of Preparation (Front to Back) 
The nine data-input forms are individually described and then illustrated below, in the same order as they are prepared: demand, supply, cost, emissions. The next section of this report, Appendix $F$, then depicts the same nine forms, in the same order, completed with sample inputs. The same sequence will be used to describe each sheet in more detail.

\section{E. 2 DEMAND. DATA}

As shown in Fig. E.2, the demand-data input consists of two types of worksheet: a "Community Demand" cover sheet, and a number of "Grid Square Demand" sheets for the grid-square data.

\section{E.2.1 Community-Demand Worksheet}

This sheet establishes the base demand data for the entire community. At a minimum, only the base " $X$ " grid line needs be established for the initial submission. Two other areas of user input, the two tables of scaling factors, should probably be completed with values of 1.0 for the initial computer run -- this causes the model to operate on default values. In later submissions of modified scenarios, the scaling factors may be adjusted to account for the effects of weatherization, conservation, and other community-specific conditions and actions that could reduce demand for space heating or cooling in particular end-use sectors or for particular fuel types.

\section{E.2.2 Grid-Square-Demand Worksheet (Up to 450 copies)}

Data for each grid square include the coordinates of its snithwest corner, the floor space by building and end-use sector, and the fuel mix. ${ }^{\dagger}$ For the large-building-cooling sector, floor space should be provided only for

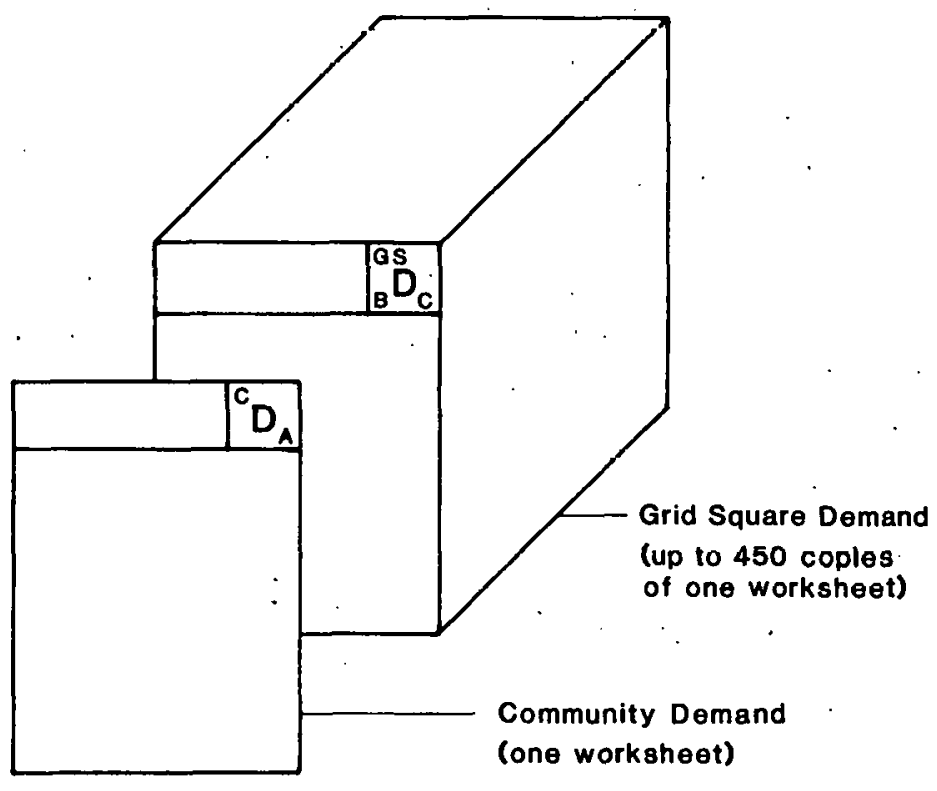

-Fig. E.2 Demand-Data Worksheets in Order of Preparation (Front to Back) 
buildings with more than $30,000 \mathrm{ft}^{2}$ (principally in high-density areas) -the economics of converting smaller buildings to district cooling, with absorption chillers using $250^{\circ} \mathrm{F}$ hot water, are questionable. Fuel mix for large-building cooling is divided between electricity and district steam from existing systems. For the industrial-process sector, the demand itself (in $10^{9} \mathrm{Btu}$ ) is given along with fuel mix. The maximum number of grid squares to which data can be attributed is 450 .

The matrix of $1-\mathrm{km}^{2}$ cells should measure no more than $32 \mathrm{~km}$ from east to west and $50 \mathrm{~km}$ from north to south. The grid-square numbering order must start in the southernmost row at the square nearest to the southwestern corner, then go west to east; the numbering of bottom-row squares ends after the row's easternmost square is numbered, and on the next row up the west-toeast numbering process begins again. (See Figs. G.4 and G.5.) Only squares with demand data need to be numbered.

The sequence in which the grid squares are entered will determine the grid-square identification numbers. Once a square is assigned a number, the number should not be changed. All grid-square coordinates must be entered as integer numbers.

To prepare the data for a given city, it is useful to have a map of the city, broken down into the various zones (e.g., census tracts, transportation planning zones) by which floor-space and fuel-mix data are available and collected. All such data must be put into a grid-square system. (See Appendix G).

For simplicity, grid squares with little or no thermal demand (e.g., lightly developed or undeveloped open space, parks, agricultural areas, and sites containing single-family homes on large lots) need not be encoded.

\section{E.3 SUPPLY DATA}

The supply-data input starts with the "Scenario Definition" sheet. If only a part of a community described by the "Grid Square Demand" sheets is being examined for district heating, the "Scenario Definition" sheet is followed by one (or up to two) "Boundary Identification" sheets. Following these two sheets are the station packages consisting of one "Station" sheet and one or more "Unit Definition" sheets for each station each. This sequence is shown in Fig. E.3.

\section{E.3.1 Scenario-Definition Worksheet}

One "Scenario Definition" sheet must be supplied for each model run. This' sheet displays the basic end-use parameters by sector and basic economic data necessary to establish the performance of a district heating and cooling system.

\section{E.3.2 Boundary-Identification Worksheet (Optional)}

If the "Scenario Definition" sheet specifies that only a certain geographical portion of the community will be analyzed, the "Boundary 


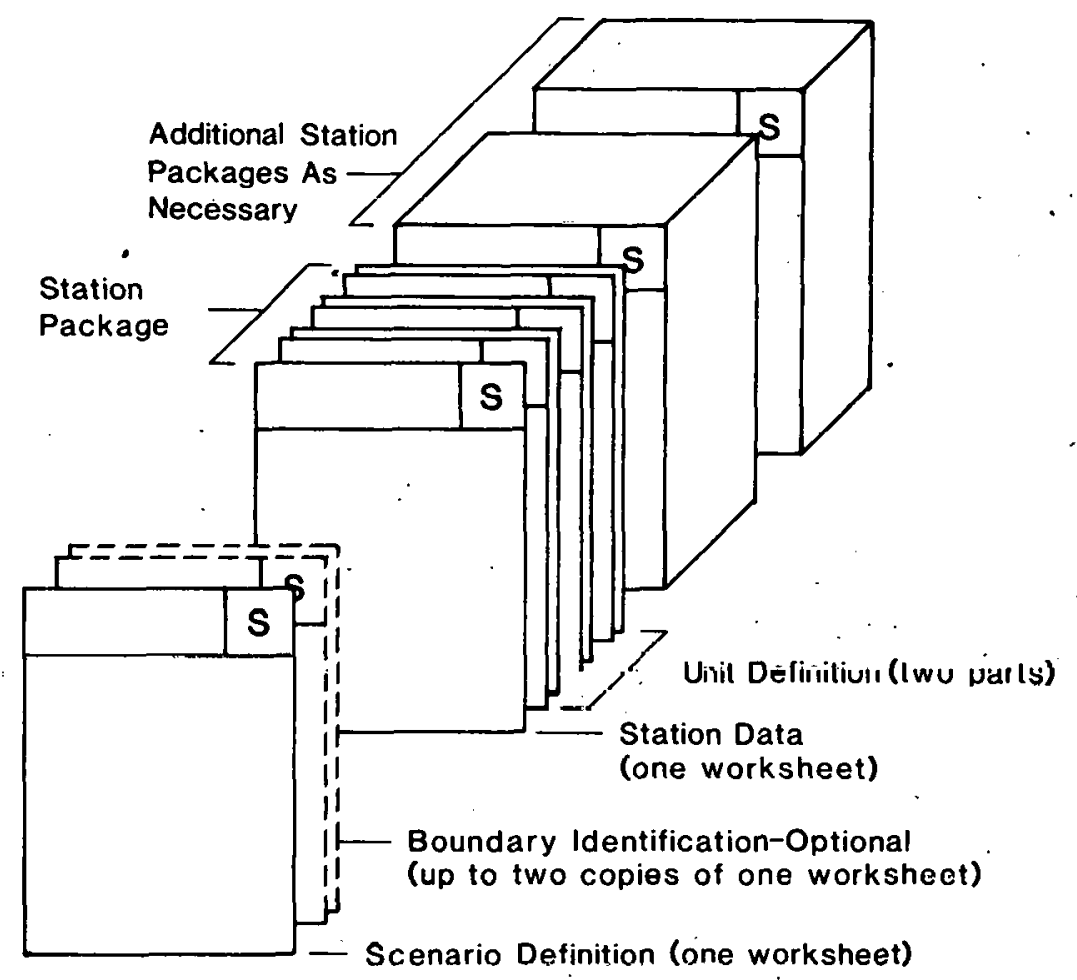

\section{Fig. E.3 Supply-Data Worksheets in Order of Preparation (Front to Back)}

Identification" sheet must be included. It can be omitted, however, when all the defined grid squares in a community are to be analyzed. A gridded map may be submitted to ANL for coding; otherwise, each data grid square to be included in the scenario must be enumerated on the form. Whenever a geographical limitation is imposed on the model, this of course means that the maximum number of grid squares to be analyzed will be less than the total number of grid squares defined in the community's demand data file.

\section{E.3.3 Station-Data Worksheet}

A separate sheet must be provided for each existing or future station located in the community. The X-Y station location, an eight-character name; and the number of generating units in the station are required for input. Immediately after the "Station Data" sheet, each unit ${ }^{\dagger}$ within the station must be defined.

Four types of units are candidates for a district heating supply system: (1) a single-case steam turbine; (2) a multicase steam turbine; (3) a thermal unit in an existing district steam system; and (4) an existing steam-driven cogenerator. New units -- i.e., those under construction, anticipated, or that the user wishes to test as a possible thermal-supply system component -- may be included among the potential supply options. Units can be given candidate or noncandidate status and thereby may be forced into or out of consideration for the thermal-supply system. If the unit is not a 
candidate, it is assumed to incur no costs that can be ascribed to the district heating system. It is assumed to operate as before, except that electrical generation will be scaled back by an amount representing the fraction of total system generation displaced by the district system in this scenario. Each electrical generating unit, whether retrofit to cogeneration operation or not, is assumed to produce as much electricity during the winter and annually as it does normally before retrofit (minus the fractional scale back caused by electrically serviced demand displaced by the district heating system). Single-case units are assumed to be permanently derated to operate in the cogeneration mode at all times.

\section{E.3.4 Unit-Definition Worksheet (Two Parts)}

For each unit in the station, a two-part "Unit Definition Data" sheet must be completed. These two sheets identify each unit, specify the actual unit type and input fuel, and document the emission performance characteristics that must be met. Each unit is also individually designated as to whether it may be considered for retrofit as part of the candidate district heating and cooling system.

\section{E.4 COST AND EMISSIONS DATA}

The last two data-input forms are the "Cost" and "Emission" sheets. Because each of these sections consists of only one sheet, all necessary description can be obtained from the sheets themselves (Sec. E.6) and from annotated examples of the completed sheets (Appendix F).

\section{E.5 SUMMARY}

The community itself is responsible for characterizing its own energy demands and supplies. The inputs forms $c$ an be therefore viewed by community planners. as a means of becoming more knowledgeable about the community's energy supply and demand systems rather than as a mechanical task.

\section{E.6 BLANK WORKSHEETS}

On each of the following nine pages is a representation of one of the blank forms used to organize input data for the district. heating strategy model. Separate quantities of blank forms are available from ANL for planners whose communities are participating in the national feasibility assessment of district heating and cooling systems. 


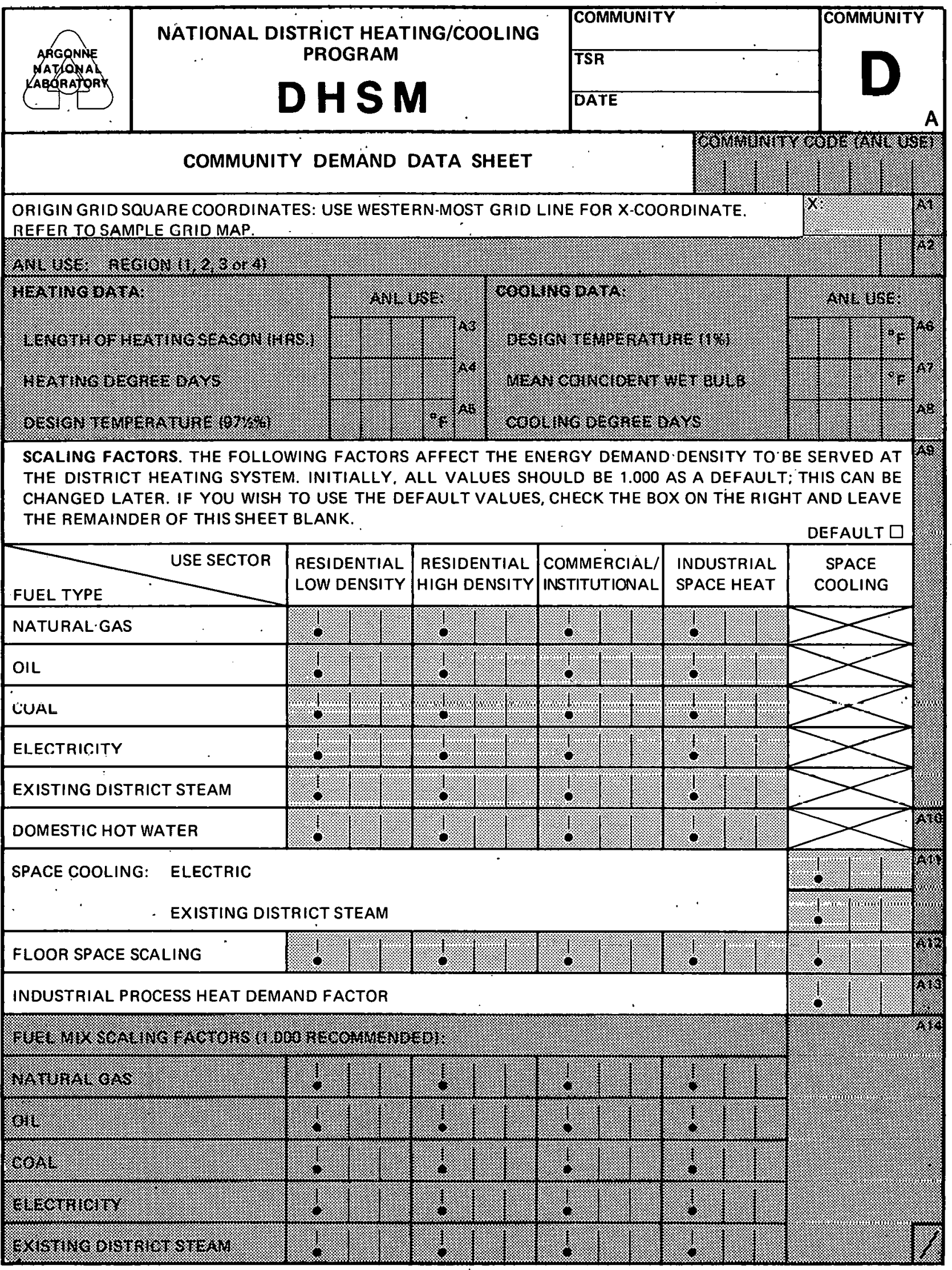




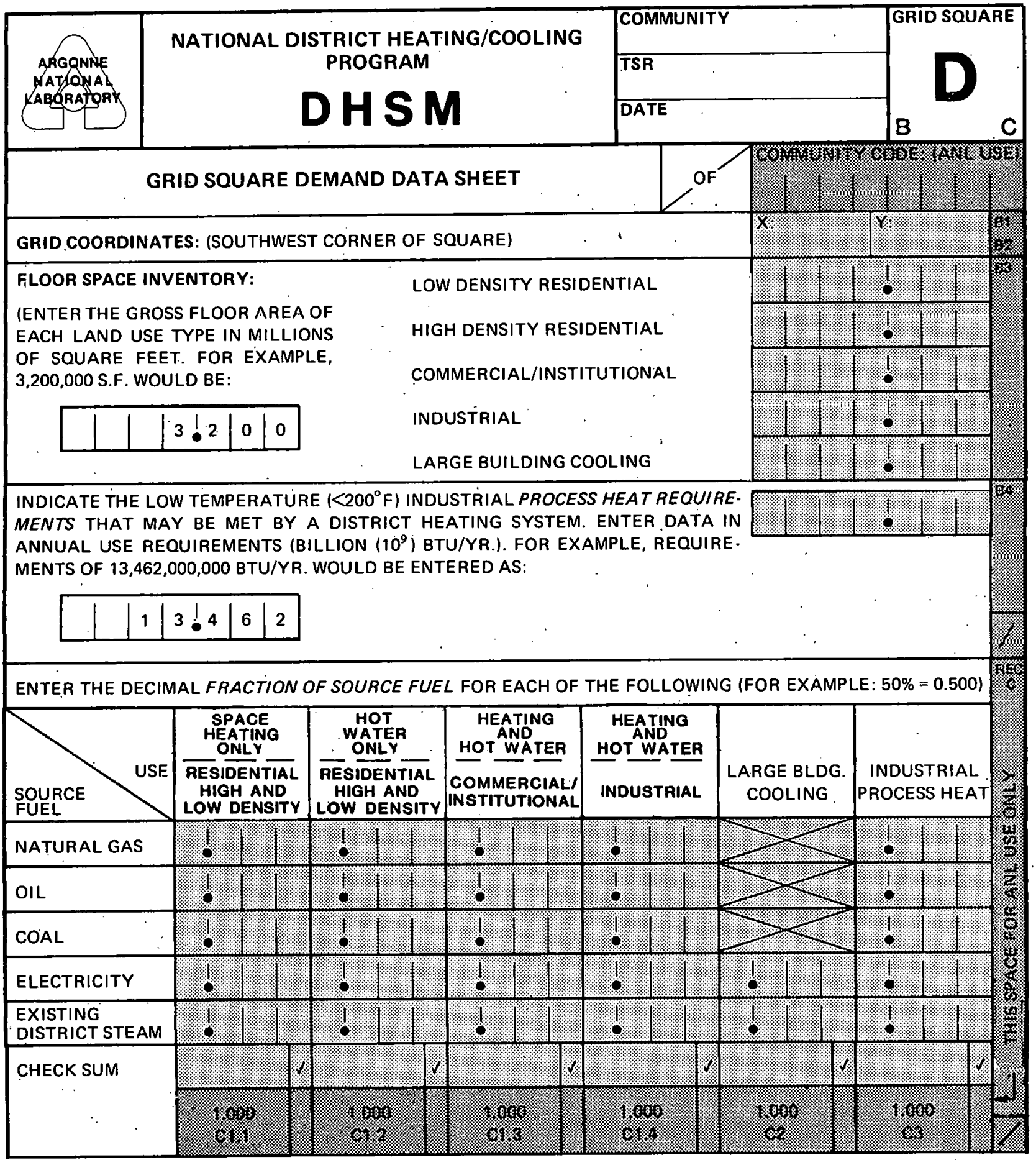




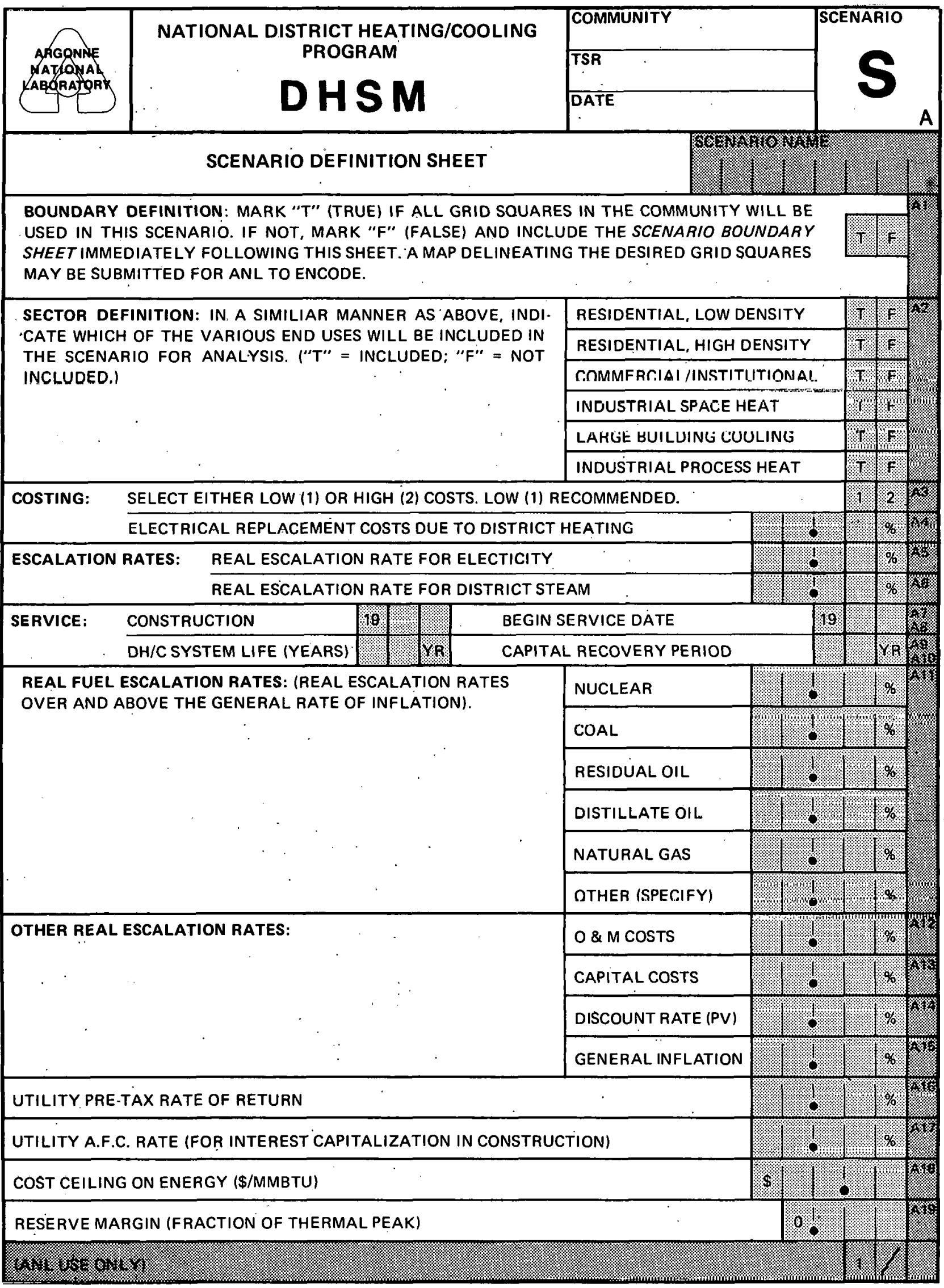




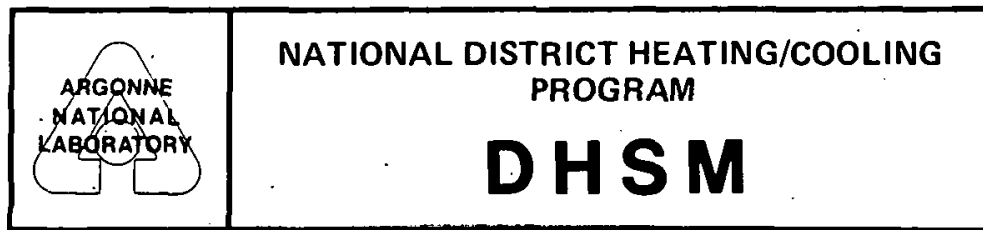

BOUNDARY IDENTIFICATION SHEET

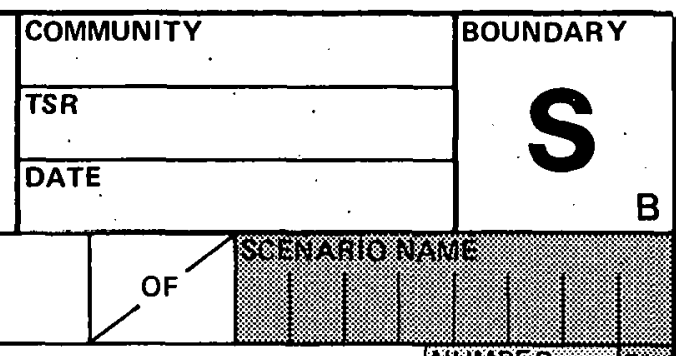

NONBER

NUMBER OF GRID SQUARES TO BE INCLUDED IN SCENARIO

LIST THE GRID SQUARES BELOW, OR CHECK BOX IF A MAP HAS BEEN INCLUDED FOR ANL TO ENCODE.

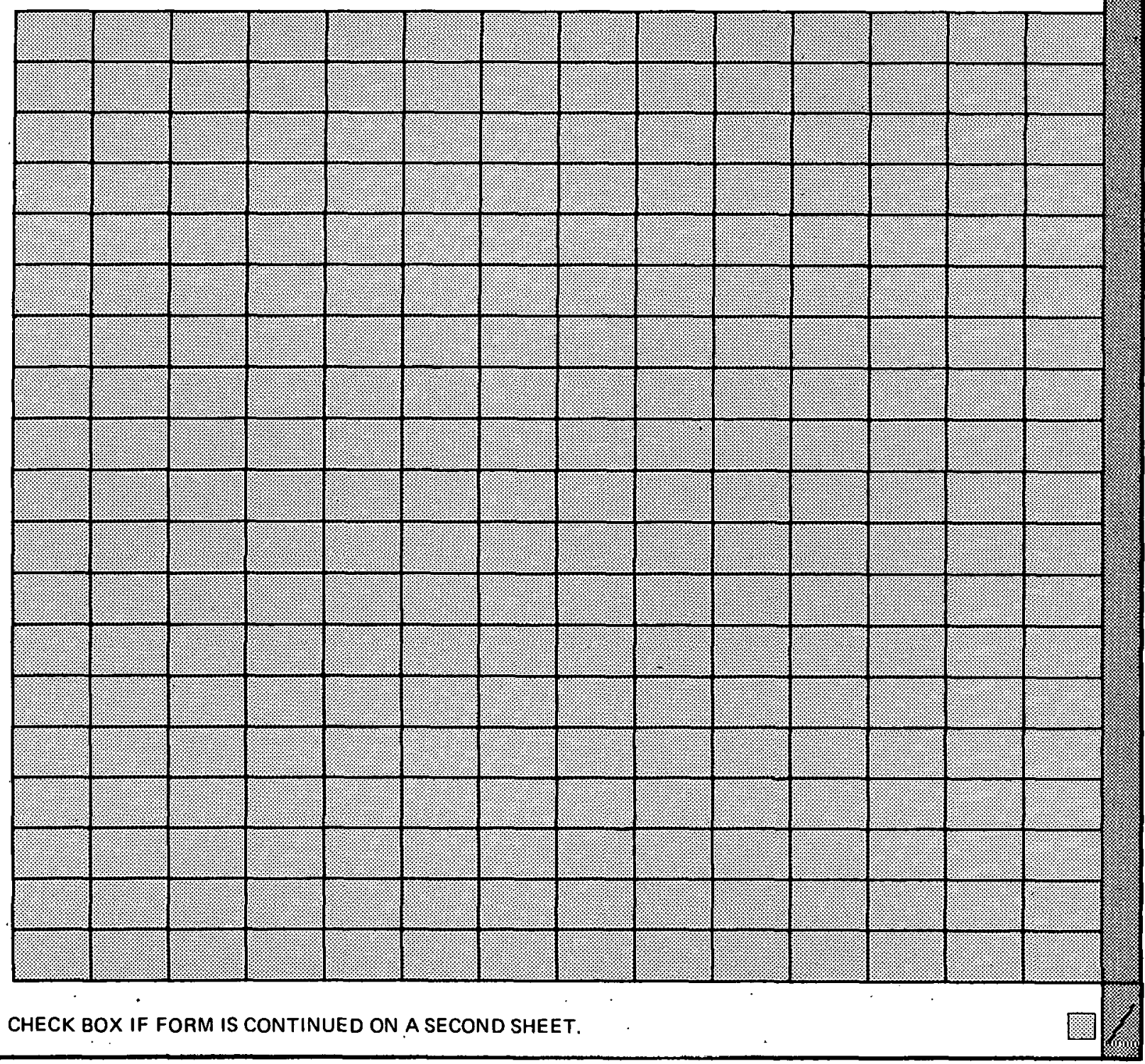




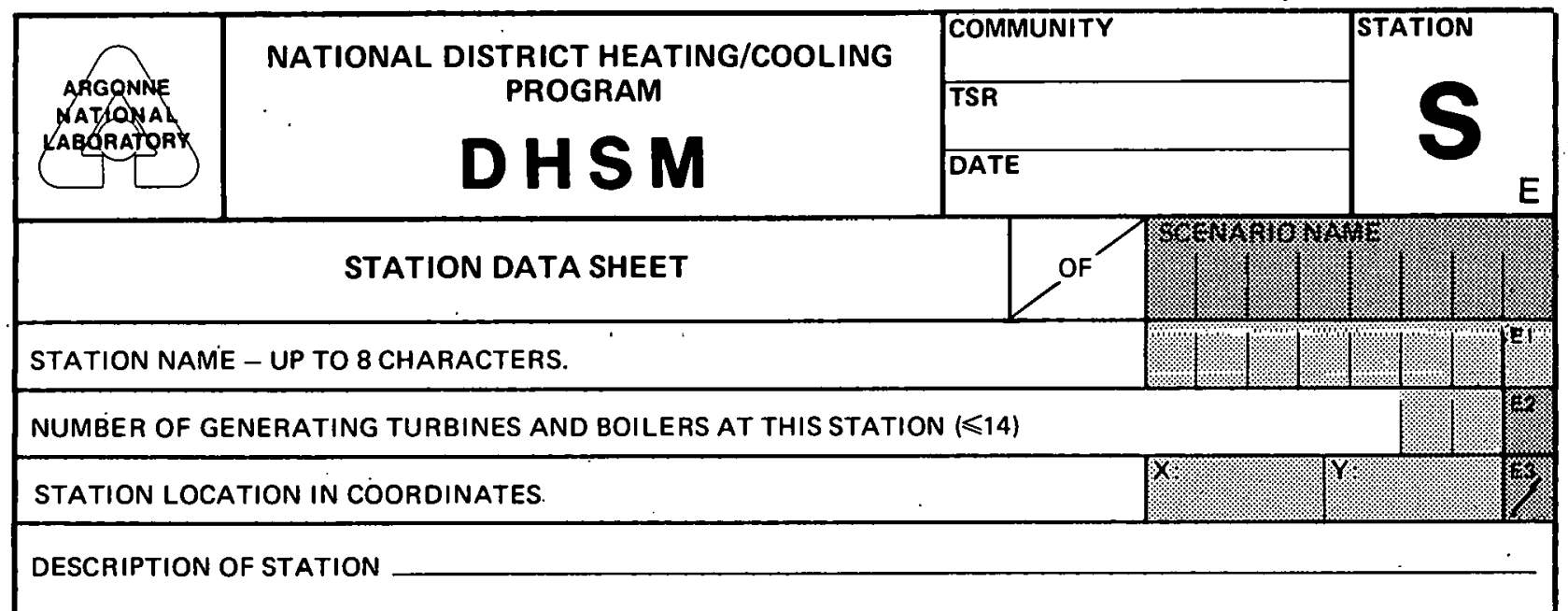

STOP. THIS DATA SHEET IS COMPLETE. FOR EACH GENERATING TURBINE OR BOILER AT THIS STATION A UNIT DEFINITION DATA SHEET MUST BE SUPPLIED. EACH UNIT DEFINITION DATA SHEET CONSISTS OF 2 PAGES, BOTH OF WHICH MUST BE COMPLETED AS PER THE INSTRUCTIONS AND ATTACHED IN SEQUENCES BEHIND THIS STATION DATA SHEET. ONLY WHEN ALL UNITS HAVE BEEN ENTERED ON THE UNIT DEFINITION DATA SHEETS FOR THIS STATION MAY YOU PROCEED TO ENTER THE NEXT STATION DATA SHEET.

IF THIS IS THE LAST STATION, PROCEED TO THE COST DATA SHEET WHEN ALL UNITS HAVE BEEN ENTERED.

NOTE: THERE MUST BE AT LEAST ONE AND NOT MORE THAN FOURTEEN UNITS AT ANY STATION. IF MORE THAN 14 UNITS EXIST AT ANY STATION, ENTER THE FIRST 14 SUCH UNITS AS USUAL AND THEN STOP. CREATE A SECOND "STATION" BY FILLING OUT ANOTHER STATION DATA SHEET FOR THE REMAINING UNITS BY SPECIFY. ING A "NEW" STATION NAME AND THE SAME UTM GRID COORDINATES. FOR EXAMPLE, THE "MAIN RIVER STATION" FOR AN IMAGINARY COMMUNITY MIGHT BE ENCODED AS BELOW:

NOTE: A TOTAL OF 21 UNITS WERE ASSUMED IN THIS EXAMPLE.

\begin{tabular}{|c|c|c|c|}
\hline MAGOAONARE & $\begin{array}{l}\text { NATIONAL DISTRICT HEATING/COOLING } \\
\text { PROGRAM } \\
\text { D HSM }\end{array}$ & \begin{tabular}{|l|} 
COMMUNITY \\
TER \\
DATE
\end{tabular} & \\
\hline \multicolumn{3}{|c|}{ STATION DATA SHEEI } & \\
\hline \multicolumn{3}{|c|}{ STATION NAME - UP TO 8 CMARACTERS. $\quad \ln |A| /|N| R|V|-\mid A$} & \\
\hline \multirow{2}{*}{\multicolumn{3}{|c|}{ 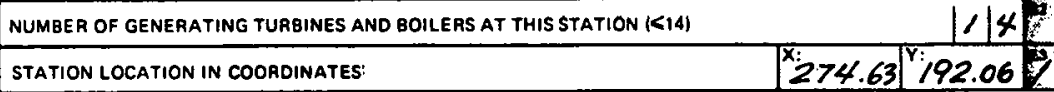 }} & \\
\hline & & & ISTATION \\
\hline \multirow{3}{*}{\multicolumn{3}{|c|}{ 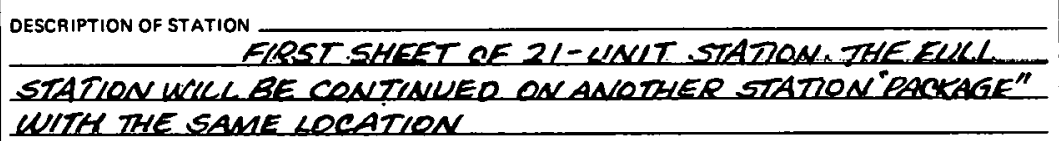 }} & \\
\hline & & & \\
\hline & & & \\
\hline & - & L & \\
\hline & STATION NAME - UP TO \& CHARACTERS. & $M|A|$ & $N|R| V \mid-B$ \\
\hline & NUMBER OF GENERATING TURBINES AND BC & ERS AT THIS STATION (<14) & $\left.0.17\right|^{2}$ \\
\hline & STATION LOCATION IN COORDINATES & $\mid 274.6$ & $192.06 \%$ \\
\hline & DESCAIPTION OF STATION CONTIAVL & ITON OE "MAINRV-A" STE & $20 \times$. \\
\hline
\end{tabular}




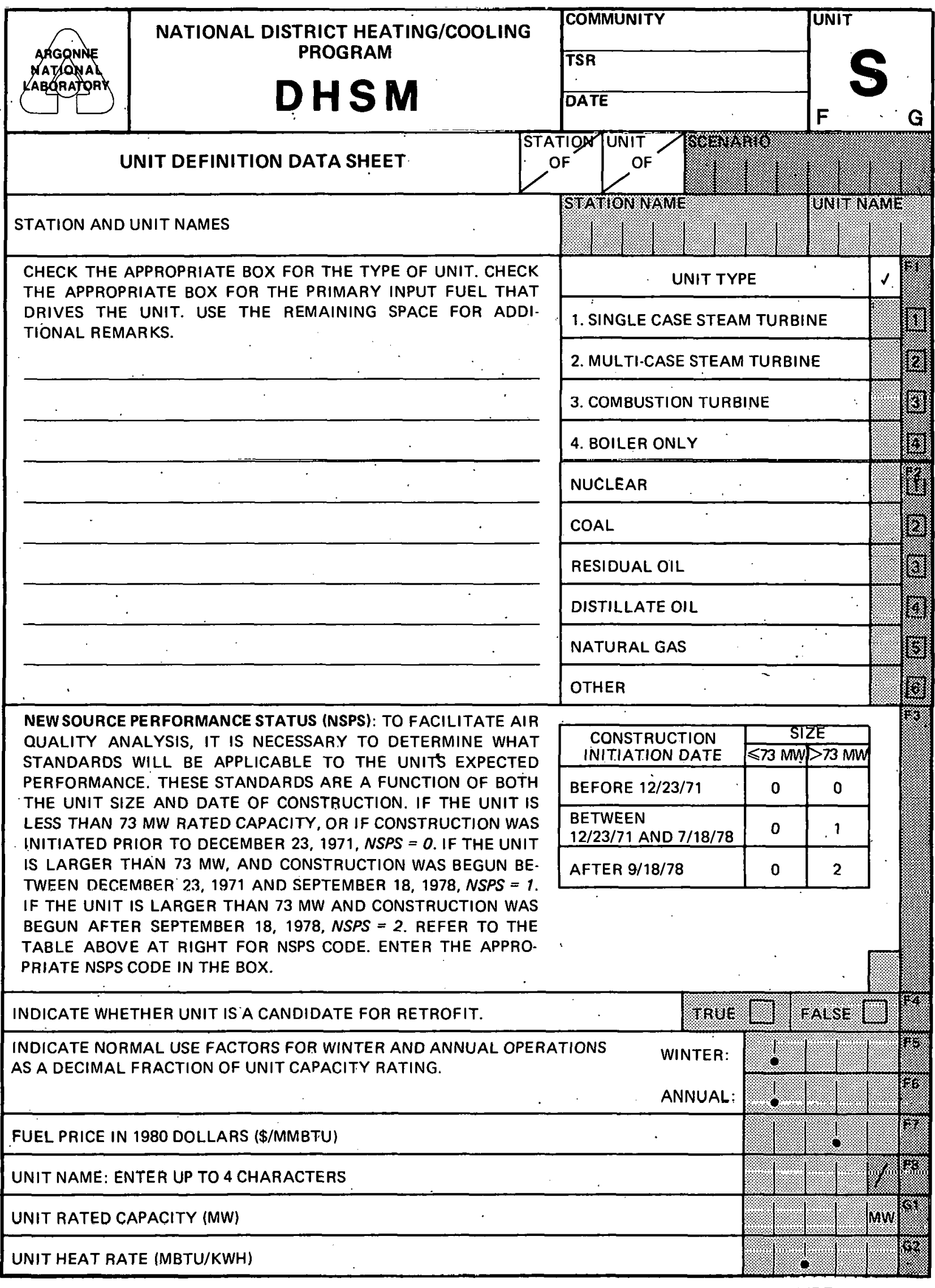




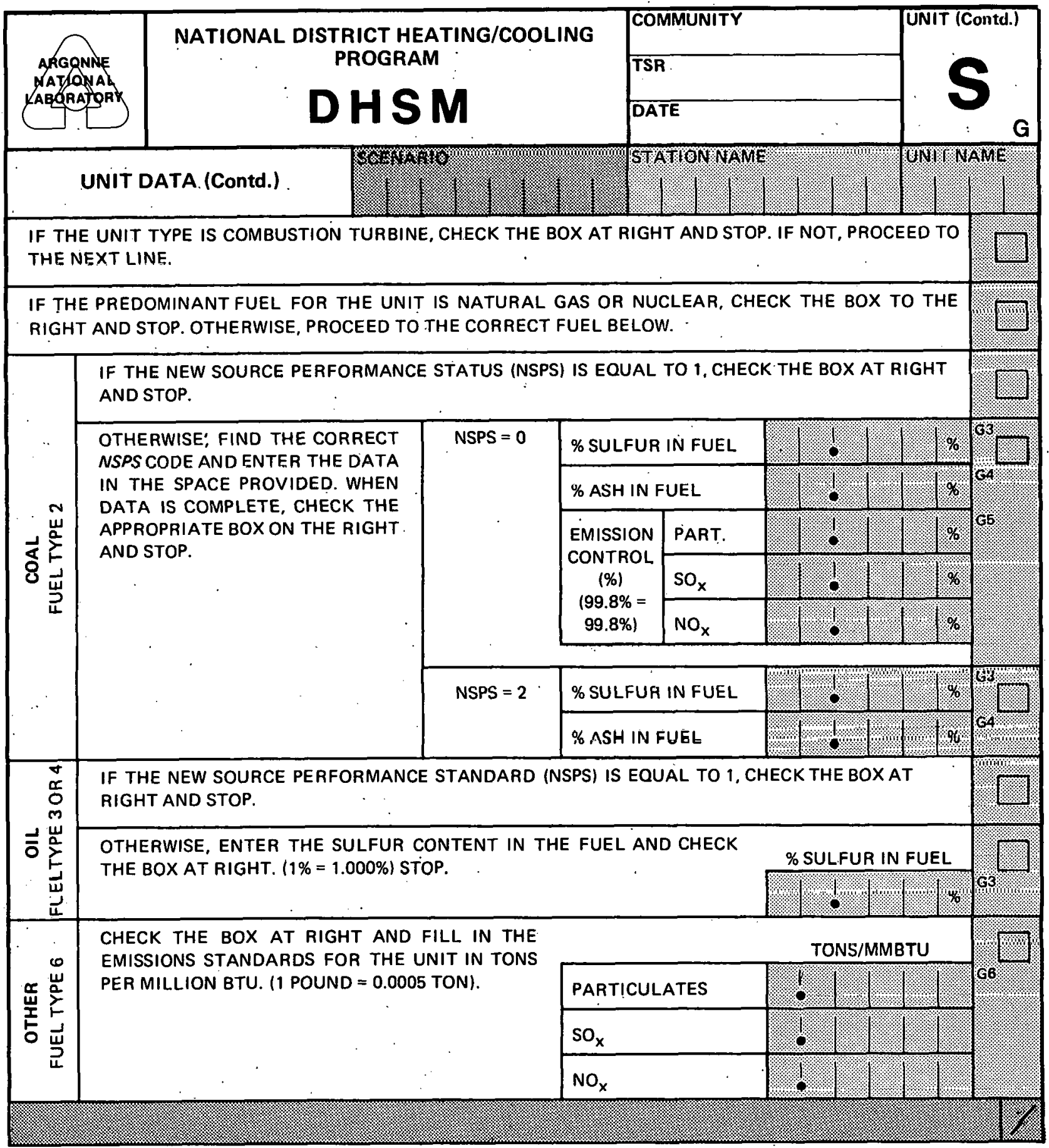




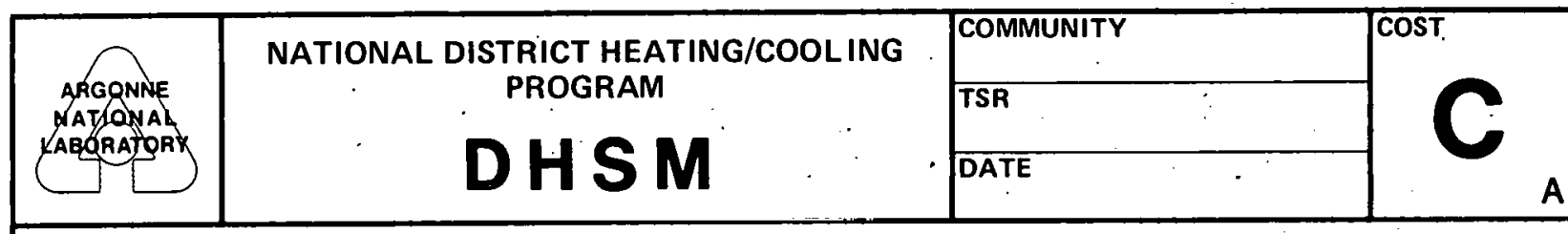

FUEL COST DATA SHEET

ENTER THE COST OF FUEL IN THE LOCAL AREA. IF DELIVERY PRICES OR RATES VARY AS A FUNCTION OF CONSUMPTION, SELECT AN AVERAGE VALUE FOR EACH TYPE OF USE INDICATED. ENTER ALL VALUES AS DOLLAR PER MILLION BTU. SUGGESTED CONVERSION FACTORS ARE INDICATED BELOW.

\begin{tabular}{|c|c|c|c|c|c|c|}
\hline & $\begin{array}{l}\text { RESIDENTIAL } \\
\text { LOW DENSITY }\end{array}$ & $\begin{array}{l}\text { RESIDENTIAL } \\
\text { HIGH DENSITY }\end{array}$ & $\begin{array}{l}\text { COMMERCIAL// } \\
\text { INSTITUTIONAL }\end{array}$ & $\begin{array}{l}\text { INDUSTRIAL } \\
\text { SPACE HEAT }\end{array}$ & $\begin{array}{l}\text { LARGE BLDG. } \\
\text { COOLING }\end{array}$ & $\begin{array}{l}\text { INDUSTRIAL } \\
\text { PROCESS HEAT }\end{array}$ \\
\hline NATURAL GAS & 90 & 8 & 1 & 18 & & $\%$ \\
\hline OIL & 8 & 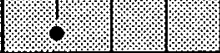 & 19 & 8 & & . \\
\hline COAL & 19 & 18 & 8 & 18 & & 8 \\
\hline ELECTRICITY & 8 & 10 & 18 & $4 \%$ & 8 & 18. \\
\hline $\begin{array}{l}\text { EXISTING } \\
\text { DISTRICT STEAM }\end{array}$ & $1 \%$ & 19. & 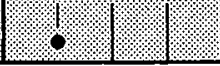 & 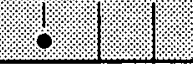 & $8 \%$ & 1. \\
\hline
\end{tabular}

USE THIS SPACE FOR COMPUTATIONS, AS NECESSARY. TYPICAL HEAT VALUES FOR EACH FUEL TYPE ARE LISTED FOR YOUR REFERENCE. IF STANDARD LOCAL VALUES ARE DIFFERENT, USE THEM.

$\begin{array}{lc}\text { NATURAL GAS: } & 1,016 \mathrm{BTU} / \mathrm{C} . \mathrm{F} . \\ \text { DISTILLATE OIL: } & 138,690 \mathrm{BTU} / \mathrm{GAL} . \\ \text { RESIDUAL OIL: } & 149,690 \mathrm{BTU} / \mathrm{GAL} . \\ \text { ANTHRACITE COAL: } & 25.2 \mathrm{MMBTU} / \mathrm{TON} \\ \text { ELECTRICITY: } & 3,412 \mathrm{BTU} / \mathrm{KWH}, \\ \text { STEAM: } & \cdot 1,000 \mathrm{BTU} / \mathrm{BB} .\end{array}$

\begin{tabular}{|c|}
\hline EXAMPLES: \\
\hline $\begin{array}{l}\text { ELECTRICITY @ } 5.75 \text { \&/KWH } \\
\frac{\$ 0.0575}{3412} \times 1,000,000= \\
\$ 16.85 / \mathrm{MMBTU} .\end{array}$ \\
\hline $\begin{array}{l}\text { OIL (DISTILLATE) @ 1.20/GAL. } \\
\frac{\$ 1.20}{149,690} \times 1,000,000= \\
\$ 8.016 / \mathrm{MMBTU}\end{array}$ \\
\hline $\begin{array}{l}\text { NATURAL GAS @ 47.24/100 GF. } \\
\frac{\$ 0.472}{100} \times \frac{1,000,000}{1,016}=. \\
\$ 4.657 / \mathrm{MMBTU}\end{array}$ \\
\hline
\end{tabular}




\begin{tabular}{|c|c|c|c|c|c|c|c|}
\hline \multirow{3}{*}{ 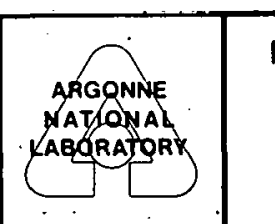 } & \multirow{2}{*}{\multicolumn{3}{|c|}{$\begin{array}{c}\text { NATIONAL DISTRICT HEATING/COOLING } \\
\text { PROGRAM }\end{array}$}} & \multicolumn{2}{|c|}{ COMMUNITY } & \multicolumn{2}{|l|}{ EMISSIONS } \\
\hline & & & & \multicolumn{2}{|l|}{ TSA } & \multirow{2}{*}{\multicolumn{2}{|c|}{ B }} \\
\hline & & & & DATE. & & & \\
\hline \multicolumn{6}{|c|}{ EMISSIONS INPUT DATA SHEET } & 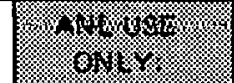 & \% \\
\hline \multicolumn{6}{|c|}{$\begin{array}{l}\text { END USE EFFICIENCIES, BY FUEL TYPE AND END USE: ENTER BELOW THE AVERAGE FUEL } \\
\text { EFFICIENCIES IN DECIMAL FRACTIONS. (50\% EFFICIENCY WOULD BE O.500). IF DEFAULT } \\
\text { VALUES ARE DESIRED, LEAVE THE FOLLOWING SECTION BLANK AND CHECK THE BOX TO } \\
\text { THE RIGHT. }\end{array}$} & OEFAQLT: & \\
\hline \begin{tabular}{l|l|l|l|l} 
END USE \\
FUEL TYPE
\end{tabular} & $\begin{array}{l}\text { RESIDENTIAL } \\
\text { LOW DENSITY }\end{array}$ & $\begin{array}{l}\text { RESIDENTIAL } \\
\text { HIGH DENSITY }\end{array}$ & $\begin{array}{l}\text { COMMERCIAL } \\
\text { INSTITUTIONAL }\end{array}$ & $\begin{array}{l}\text { INDUSTRIAL } \\
\text { SPACE HEAT }\end{array}$ & $\begin{array}{l}\text { LARGE BLDG. } \\
\text { COOLING }\end{array}$ & $\begin{array}{c}\text { INDUSTRIAL } \\
\text { PROCESS HEAT }\end{array}$ & \\
\hline NATURAL GAS & 18. & 1.: & \%. & & $=2$ & :. & ?: \\
\hline OIL & ?. & 4. & (1) & 10 & & 1. & ?:-20 \\
\hline COAL & (1) & 1. & 1. & 1. & $=$ & . & 3 \\
\hline ELECTRICCITY & 18 & 8 & .1. & & .0 & & 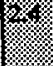 \\
\hline $\begin{array}{l}\text { EXISTING } \\
\text { DISTRICT STEAM }\end{array}$ & 1918.1018 & $1.1 .1 .17 .1 .1 \%$ & 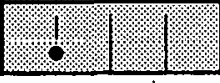 & $1.1 .1 .1 .1 .1 \%$ & 1.1 .1 .19 .1 .19 & 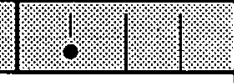 & 1 \\
\hline \multicolumn{7}{|c|}{$\begin{array}{l}\text { OIL AND COAL USE CHARACTERISTICS, BY END USE SECTOR: FOR EACH FUEL AND END USE, ENTER THE } \\
\text { APPROPRIATE DATA. IF THERE IS NO SIGNIFICANT FUEL CHARACTERISTIC VARIATION BY USE TYPE. ALL } \\
\text { VALUES IN THE LINE WILL BE EQUAL. }\end{array}$} & 厔 \\
\hline \multicolumn{2}{|c|}{ OIL \& COAL CHARACTERISTICS: } & $\begin{array}{l}\text { RESIDENTIAL } \\
\text { LOW DENSITY }\end{array}$ & $\begin{array}{l}\text { RESIDENTIAL } \\
\text { HIGH DENSITY }\end{array}$ & $\begin{array}{l}\text { COMMERCIAL/ } \\
\text { INSTITUTIONAL }\end{array}$ & $\begin{array}{l}\text { INDUSTRIAL } \\
\text { SPACE HEAT }\end{array}$ & $\begin{array}{l}\text { INDUSTRIAL } \\
\text { PROCESS HEAT }\end{array}$ & \\
\hline \multicolumn{2}{|c|}{$\begin{array}{l}\text { DISTILLATE FRACTION OF OIL } \\
\text { USE }(50 \%=0.500)\end{array}$} & 2. & & & 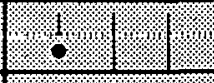 & & fil \\
\hline \multicolumn{2}{|c|}{$\begin{array}{l}\text { PERCENT SULFUR IN DISTILLATE } \\
\text { OIL, BY WEIGHT }(1.5 \%=1.500) \\
\end{array}$} & & 1. & (1. & ... & 1. & 18. \\
\hline \multicolumn{2}{|c|}{$\begin{array}{l}\text { PERCENT SULFUR IN RESIDUAL } \\
\text { OIL, BY WEIGHT }(2.4 \%=2.400) \\
\end{array}$} & & 3. & 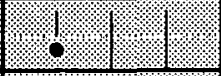 & & 88 & 13. \\
\hline \multicolumn{2}{|c|}{$\begin{array}{l}\text { PERCENT SULFUR IN COAL, BY } \\
\text { WEIGHT }(3 \%=3.000)\end{array}$} & 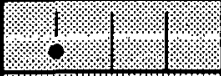 & 18 & $1.1 .10 .1 \%$ & 18 & 18. & mix \\
\hline \multicolumn{2}{|c|}{$\begin{array}{l}\text { PERCENT ASH IN COAL, BY } \\
\text { WEIGHT }(1.3 \%=1.300)\end{array}$} & . & 18 & 11.11 .17 & .1. & 8 & 9 \\
\hline \multirow{2}{*}{\multicolumn{3}{|c|}{$\begin{array}{l}\text { HEAT CONTENT OF FUELS: SPECIFY THE HEAT } \\
\text { CONTENT OF THE FUELS LISTED TO THE LEFT. } \\
\text { (TYPICAL VALUES ARE GIVEN IN PARENTHESIS). }\end{array}$}} & \multicolumn{3}{|l|}{ COAL (25.2) } & 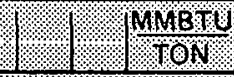 & f \\
\hline & & & \multicolumn{3}{|c|}{ RESIDUAL OIL (149.69) } & $\sqrt{\mathrm{GA} \mathrm{BH}_{1}}$ & \% \\
\hline & & & \multicolumn{2}{|c|}{ DISTILLATE OIL (138.69) } & : & . $1=1 . \mathrm{MBM}$ & 9 \\
\hline & & & \multicolumn{2}{|c|}{ NATURAL GAS (1016.0) } & & $1.1: \frac{\mathrm{Br}}{\mathrm{Cr}}$ & 18 \\
\hline
\end{tabular}


61

APPENDIX F

SAMPLE COMPLETED WORKSHEETS 
THIS PAGE

WAS INTENTIONALLY

LEFT BLANK 


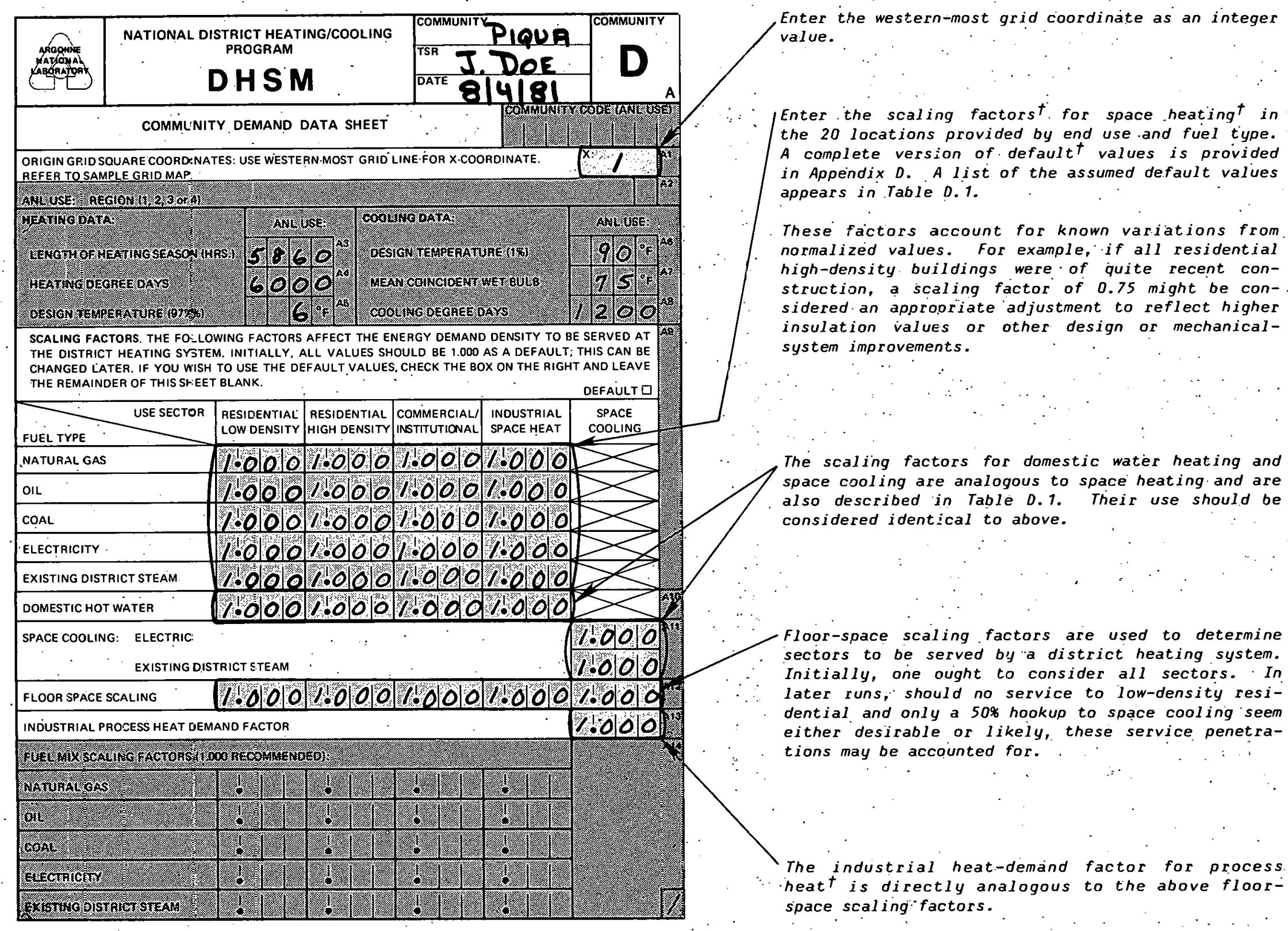




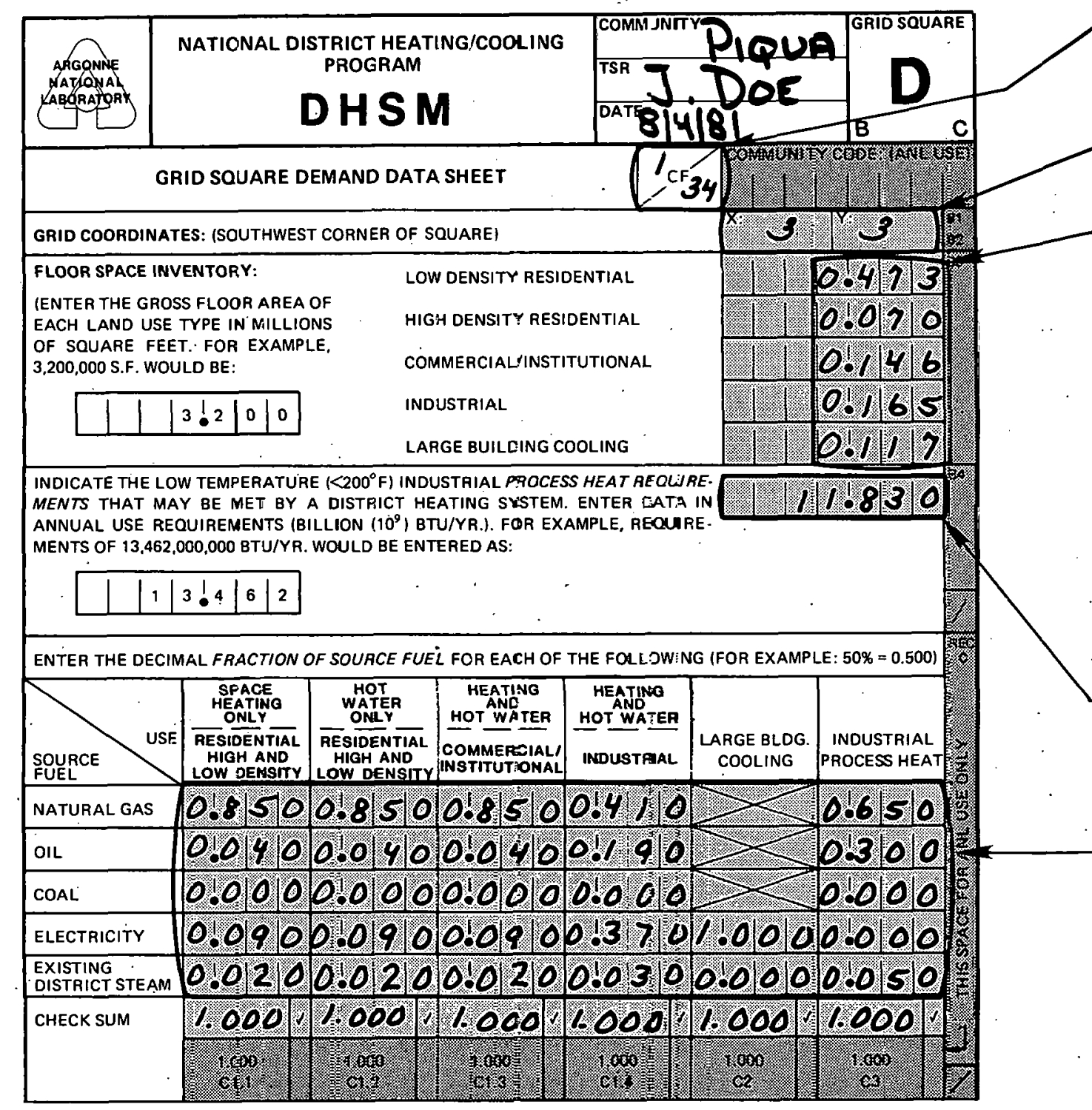

for acjuracy in later references, keep track of the sequence of input and the total number of encoded grid sijuares.

Enter the grid coordinates as integer numbers.

The aporaximate floor space for each of four major land uses must be given in $10^{6} \mathrm{ft}^{2}$. For example, if soughly half the grid square is single-family detached housing with a gross floor-area ratio (FAR) of 0.25 (1500-ft $t^{2}$ houses on 1/4-acre lots), the value would be $0.125 \times 43.560 . \mathrm{rt}^{2} /$ acre $\times 247.105$ $a c / \mathrm{km}^{2} \times 50 \%=673.000 \mathrm{ft} \mathrm{t}^{2}$, or a value of 0.673 . for the piquat example, the following square footages have been encoded into grid square 3,3:

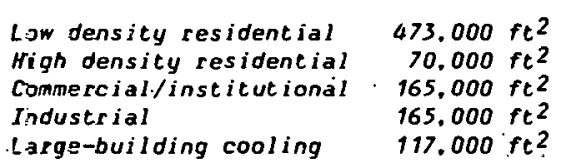

Mere, the Eotal built spaces $1854.000 \mathrm{ft}^{2}$, excluding large-juilding coolingl, is equivalent of a gross. FAR of 0.08 .

Estimate the low temperature heat requirement in $10^{\circ}$ Atu'yr. Any plant managers in the grid squace could probabiy provide a rough estimate for their ooerations.

For each type of end use, provide the fraction of energy supplied by each fuel type. If for example, 758 of the space heating for low density residential is provided by natural gas, $15 \%$ by fuel oil. $2 \%$ by coal, and $8 \%$ by electricity, the following numbers would ó filled in:

$\begin{array}{ll}\text { Natural gas } & 0.750 \\ \text { Oil } & 0.150 \\ \text { Cal } & 0.020 \\ \text { Electricity } & 0.080 \\ \text { District steam } & \underline{0.000} \\ \text { Check Sum }= & 1.000 \text { (or 100\%) }\end{array}$
This orocess is continued for all end uses. If the commity it is not necessary to cont inue to

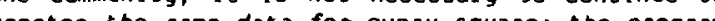
will retain the most recent entry. 


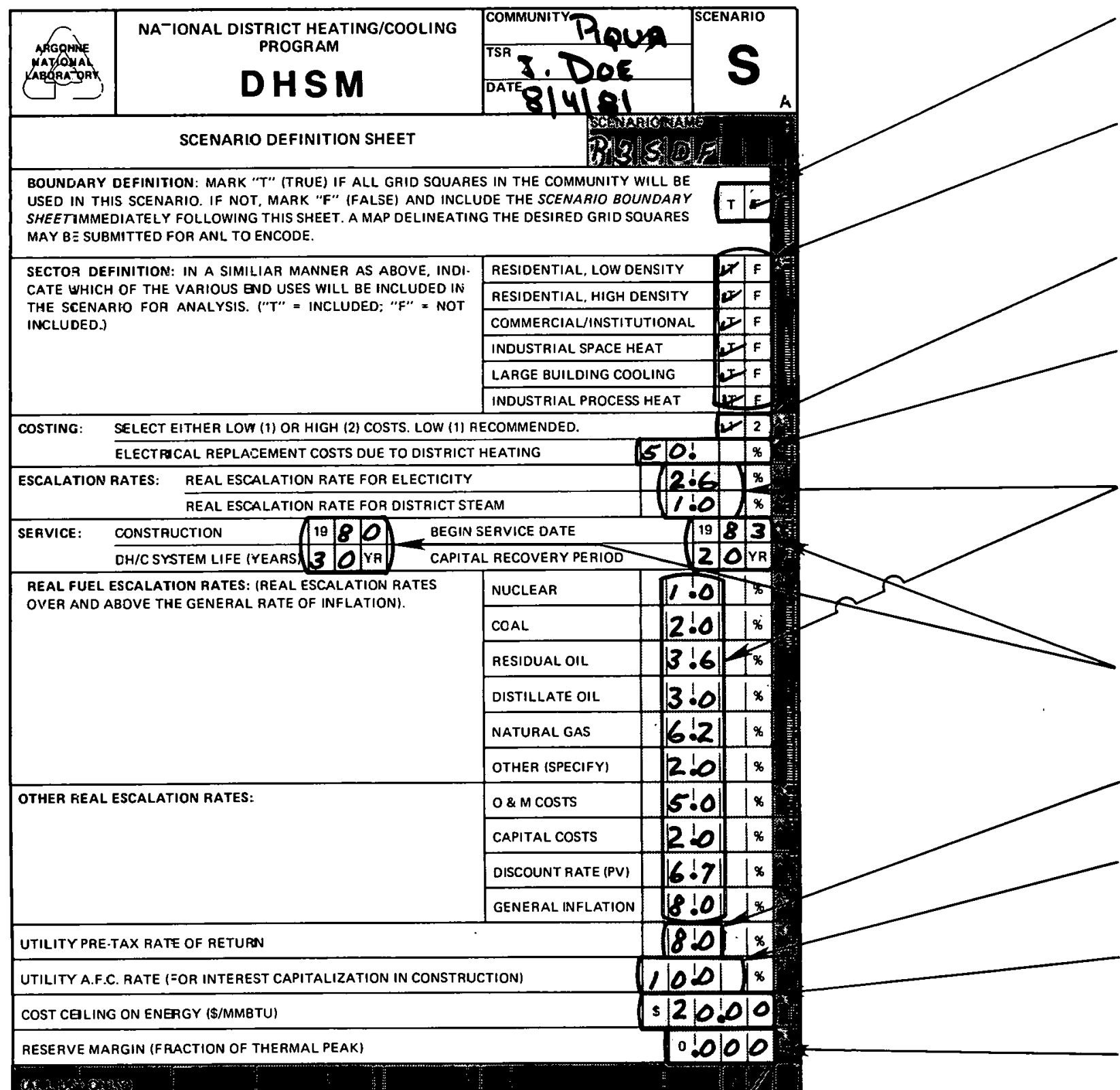

Indicate whether the entire community (all encoded grid squares) will be used in the scenario. In the example of piqua, Ohio, only a portion of the community is to be modeled.

In a similar manner, indicate if any end-use sectors should be amitted or included in the procedures. for exampie, if you do not wish to consider space cooling, you would check the " $F$ " (false) box. In the piqua example, all sectors were considered.

Tables 0.4 and 0.5 in Appendix 0 give costing values used by the program. As in the Piqua example, selection of the "low" costs is recommended.

District heating and cooling will replace some electricity output via changed capacity. The percentage here represents the generating reductions that must be replaced by revenues from the district heating system.

Real escalation ratest lover and above the general rate of inflation) must be provided. If you estimate that any rate will roughly approximate the rate of inflation, then a value of 0.00 should be entered. For example, in Piqua a long-term inflation rate of $8 x$, with a real escalation rate for natural gas of $6.2 \%$ (which translates to an annual long-term inflation rate of $14.2 \%)$, is expected.

Construction and service-initiation dates must be specified by calendar year. Periods of expected service life and capital recovery must also be rovided. Values used in the example are typical.

Rate of returnt (oefore taxes) for the utility. here, a value of $8 \%$ was selected.

Utility annual fixed change rate represents the cost of borrowing money for the utility during construction financing.

Maximum feasible price for district heating where it mould still compete with other energy sources (in mould stil.
$\$ 1106$ otul.

surplus quantity of heating capacity, beyond design sizing, can meet unexpected pertubations in safety factor. 


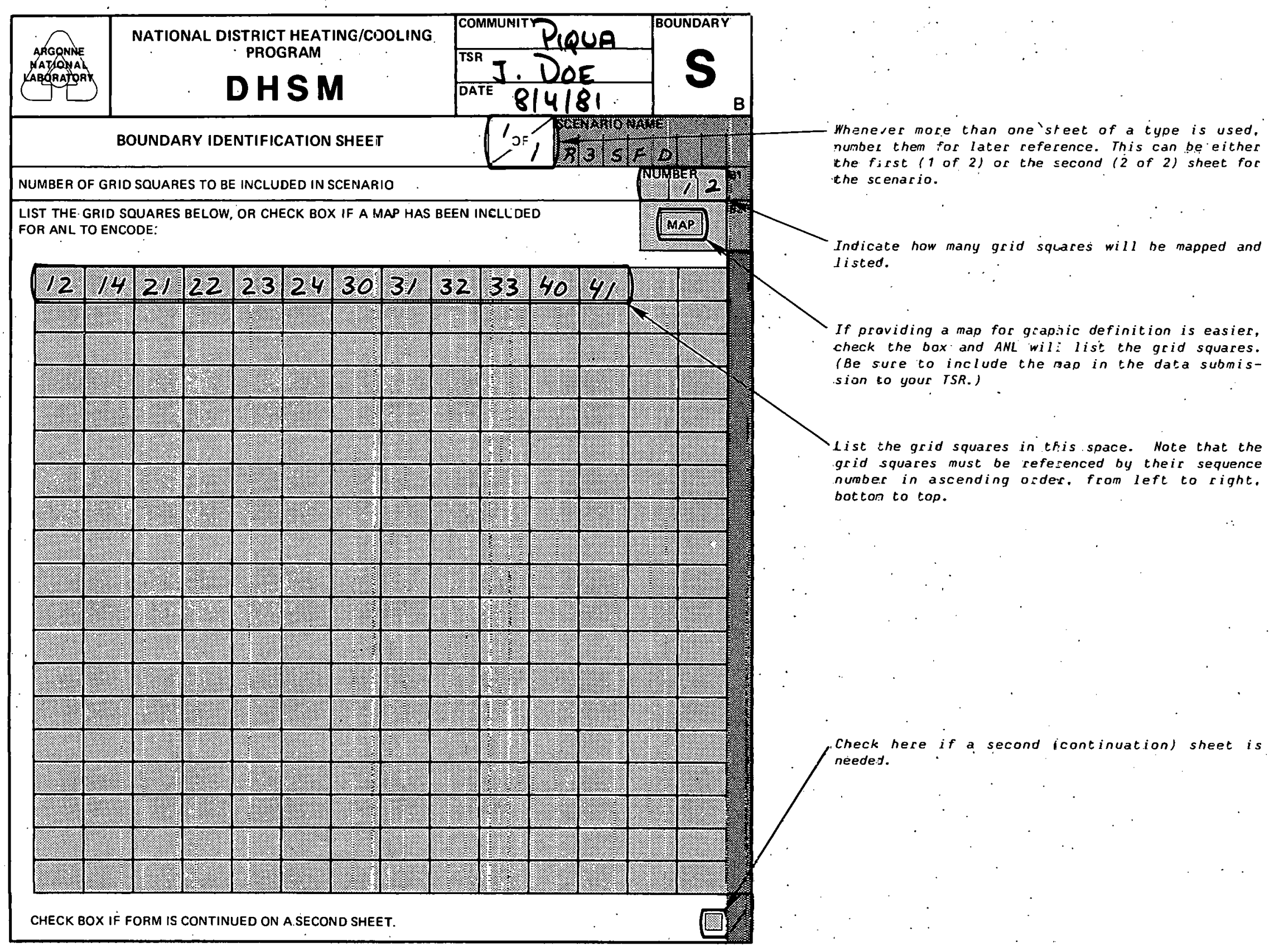




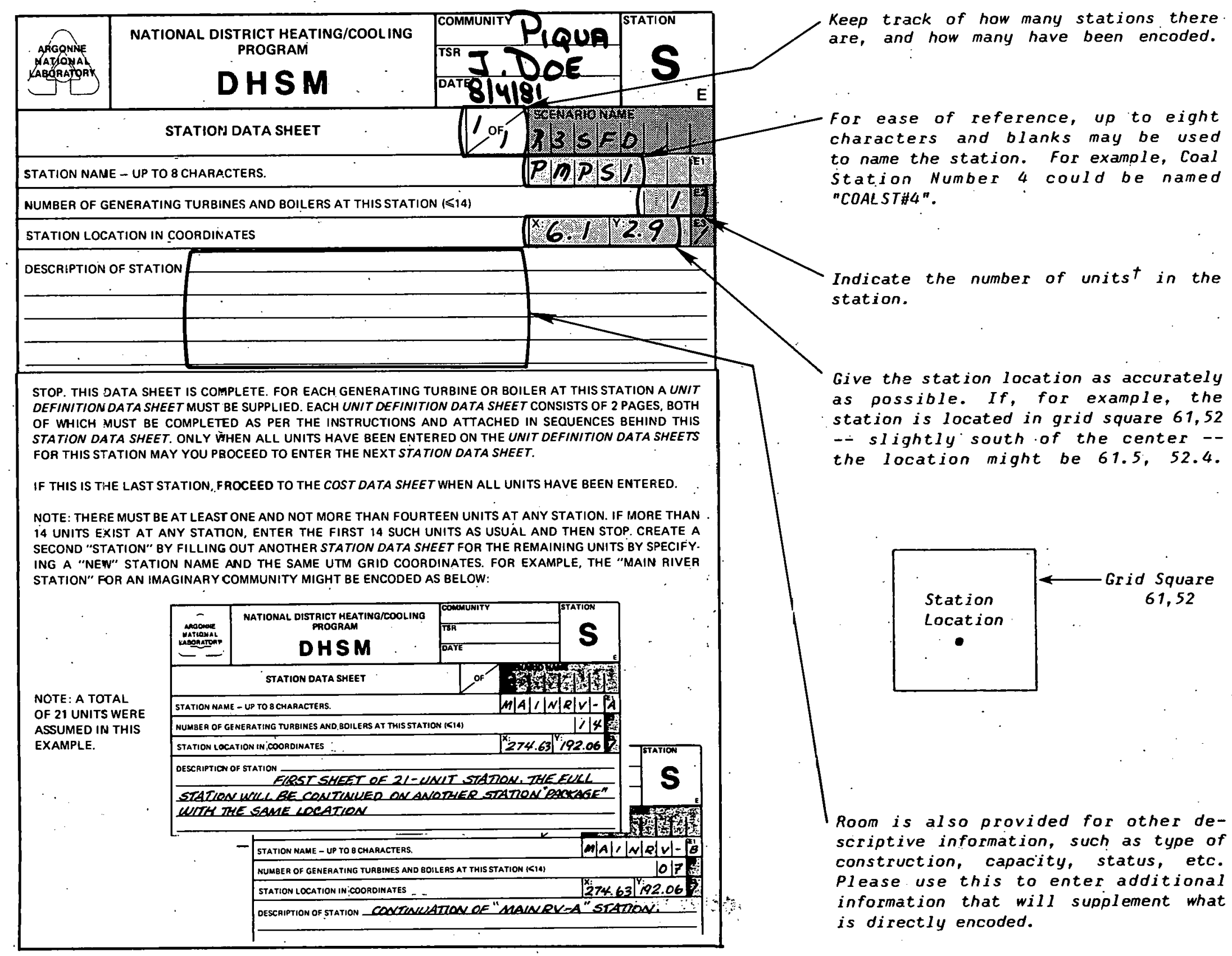




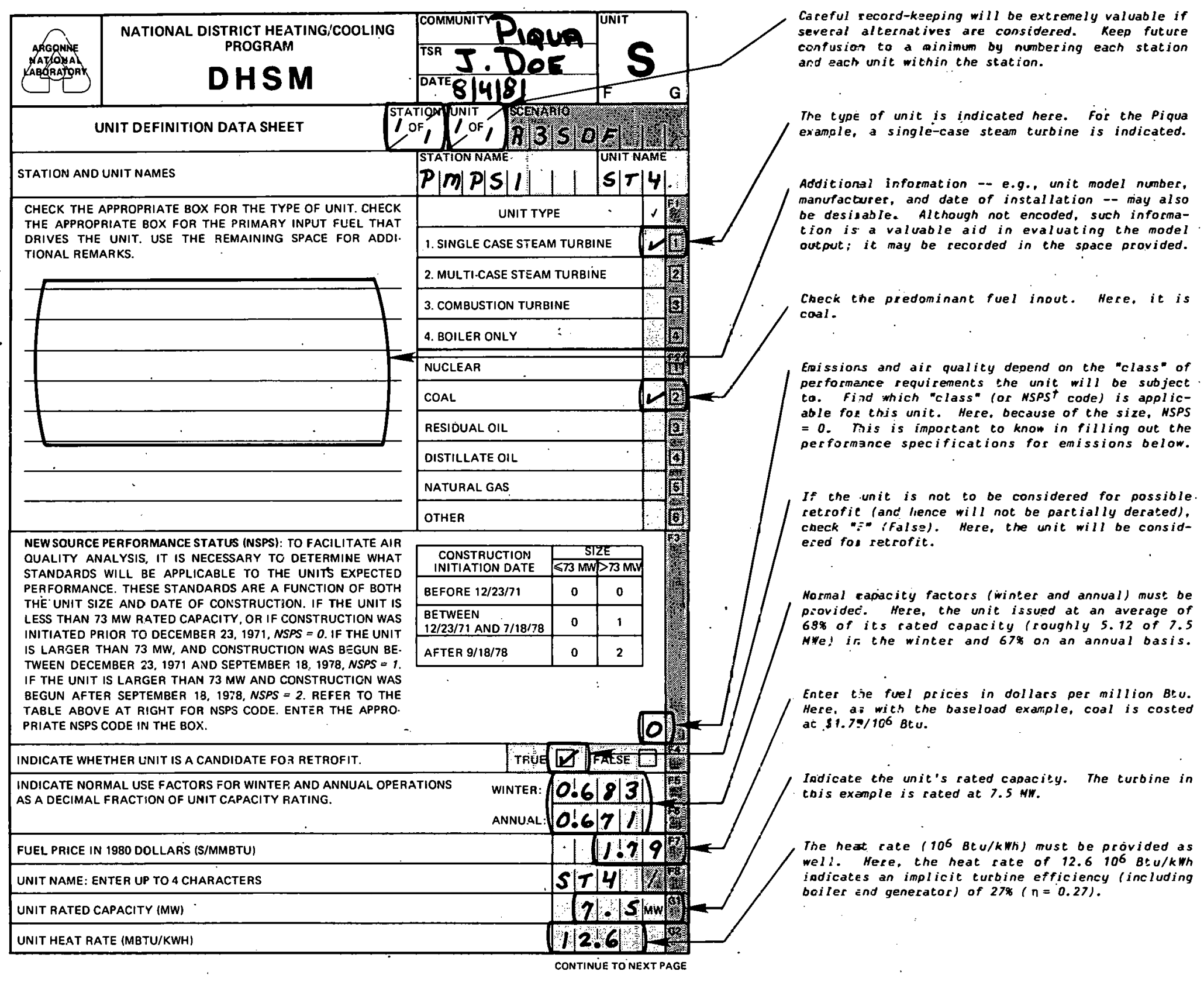




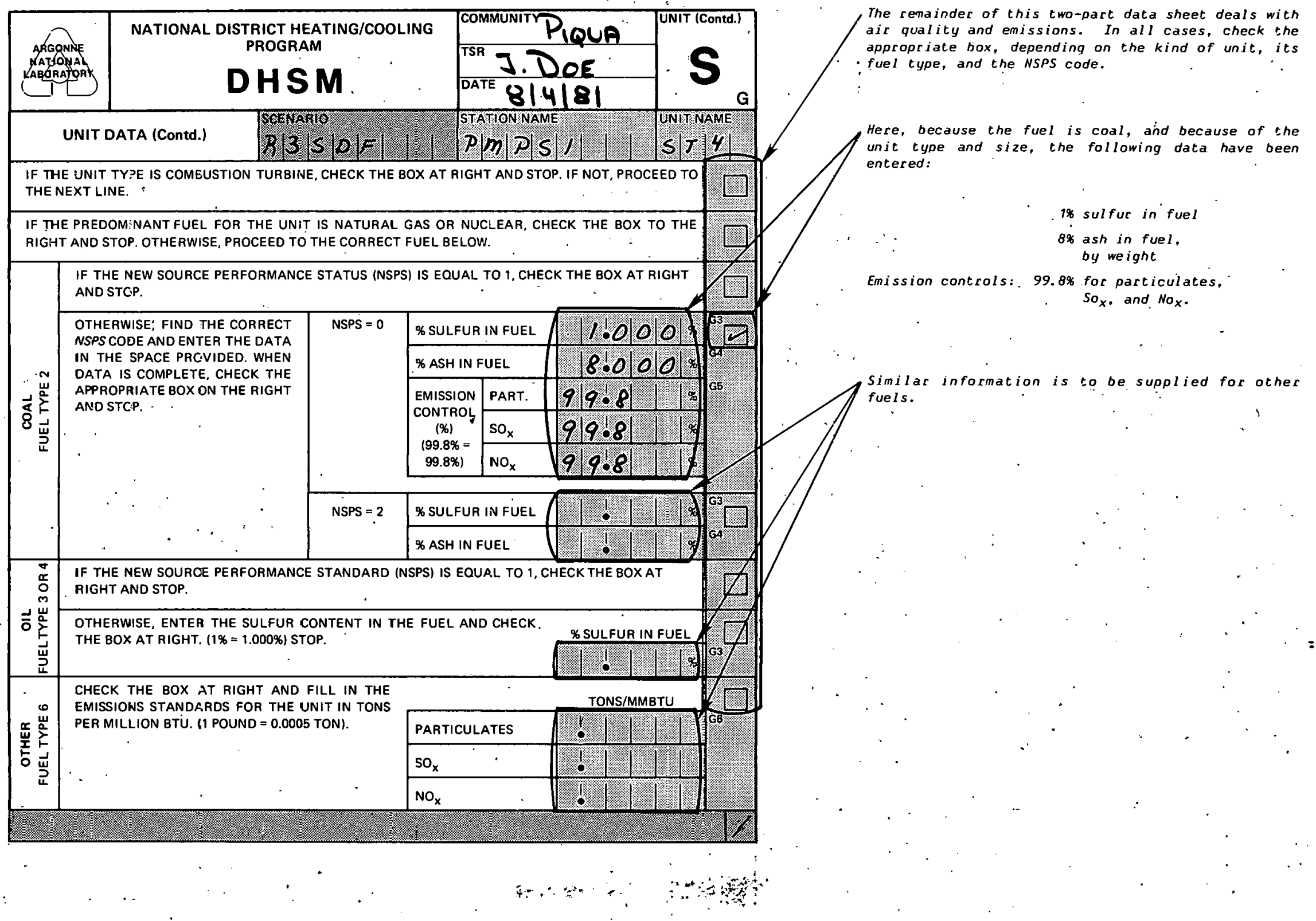




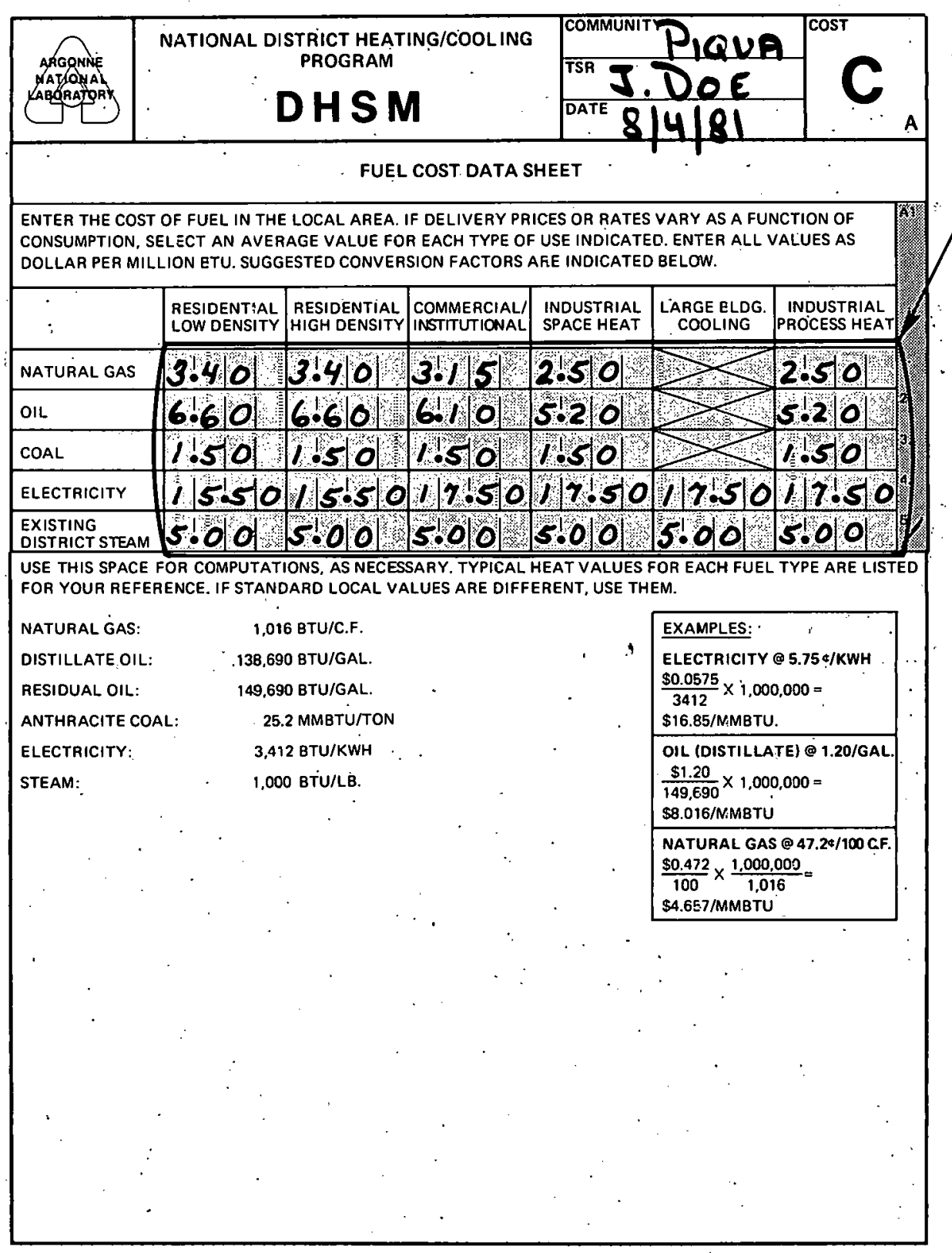

For each space provided, it is necessary to enter the nomalized cost of fuel per $10^{6} \mathrm{Btu}$. Since this is not the usual means of pricing for many kinds of fuels, conversion factors are provided to ingive generaliy accepted heat content (Btu) for common units of fuel. Cost differences will occur for a single fuei across types of uses if there are different rate schedules or delivery prices for the various fuels. If such differences do not exist in your community, all cost values for a single fuel would be the same. 


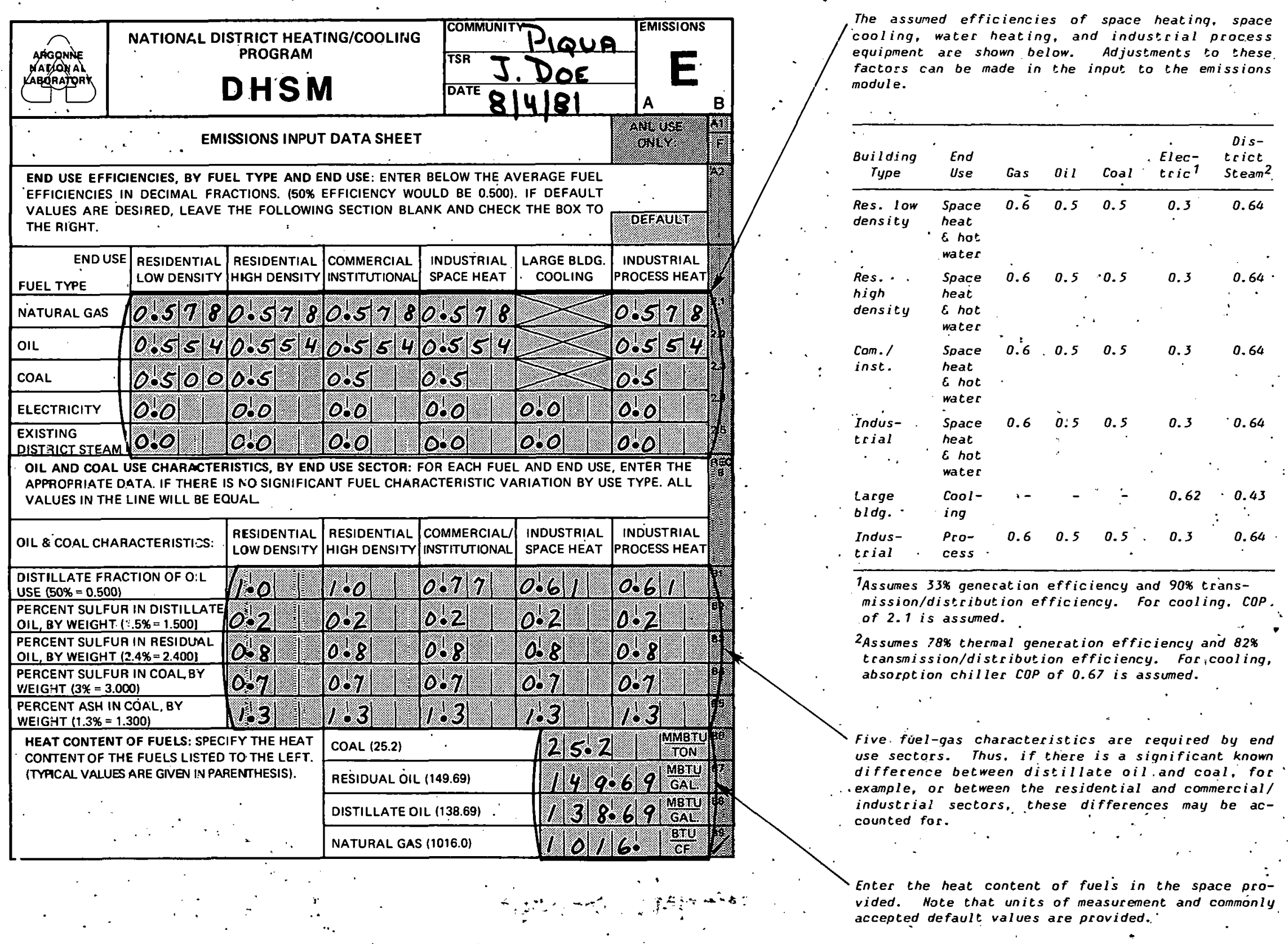


THIS PAGE

\section{WAS INTENTIONALLY \\ LEFT BLANK}




\author{
APPENDIX G \\ MAPPING A DHSM STUDY AREA \\ AND CONSTRUCTING ITS GRID SYSTEM
}

Using the district heating strategy model (DHSM) assumes that two important preliminary tasks have been completed. The first task consists of selecting and mapping the area to be modeled. Depending on local conditions, this may be a region, city, or an area with obviously good potential for using a district heating and cooling system. The second task consists of overlaying the study area with a system of $1 \mathrm{~km}$ by $1 \mathrm{~km}$ grid squares. The grid squares describe the location of various features used in the model.

\title{
Step 1: Acquire or Produce a General Study-Area Map
}

This should be a large regional map showing at least three sets of geographical data.

- Boundaries of the study area selected by a local decisionmaking process -- but in no case containing more than 450 grid squares with demand data ( 174 square miles) within a total gridded area measuring at most $32 \mathrm{~km}$ from east to west and $50 \mathrm{~km}$ from north to south.

- Boundaries of political jurisdictions in the region.

- Natural physical barriers to development of a district heating system

Detailed descriptions of each of these map features are provided below. other information (such as streets and highways) may be included but is not required. An example of a minimal general study-area map for a community is shown in Fig. G.1.

Before constructing a map, community energy planners should check to see if a usable map has already been produced by groups such as regional planning agencies, transportation authorities, the U.S. Geological Survey (USGS), or special metropolitan districts. Any large-scale map of the study area can be used provided it shows regional and political boundaries and barriers to development. The most useful base maps are the USGS 7-1/2 minute topographic maps, which can be fastened together to form a single map to cover. large areas. For cities, the USGS maps may not have sufficient detail.

If a large study-area map must be drawn from scratch, commity planners should be guided by certain principles in drawing required boundaries and showing other necessary information. The principles are described below.

$\because$ :.. Regional Boundaries. Examples of boundaries that can be used to define a study area for implementing district heating are those of a standard metropolitan statistical area (SMSA), a county, a city, or the jurisdiction of a regional planning commission. In an ideal situation these boundaries would coincide. Determining the appropriate study-area boundaries is a basic 


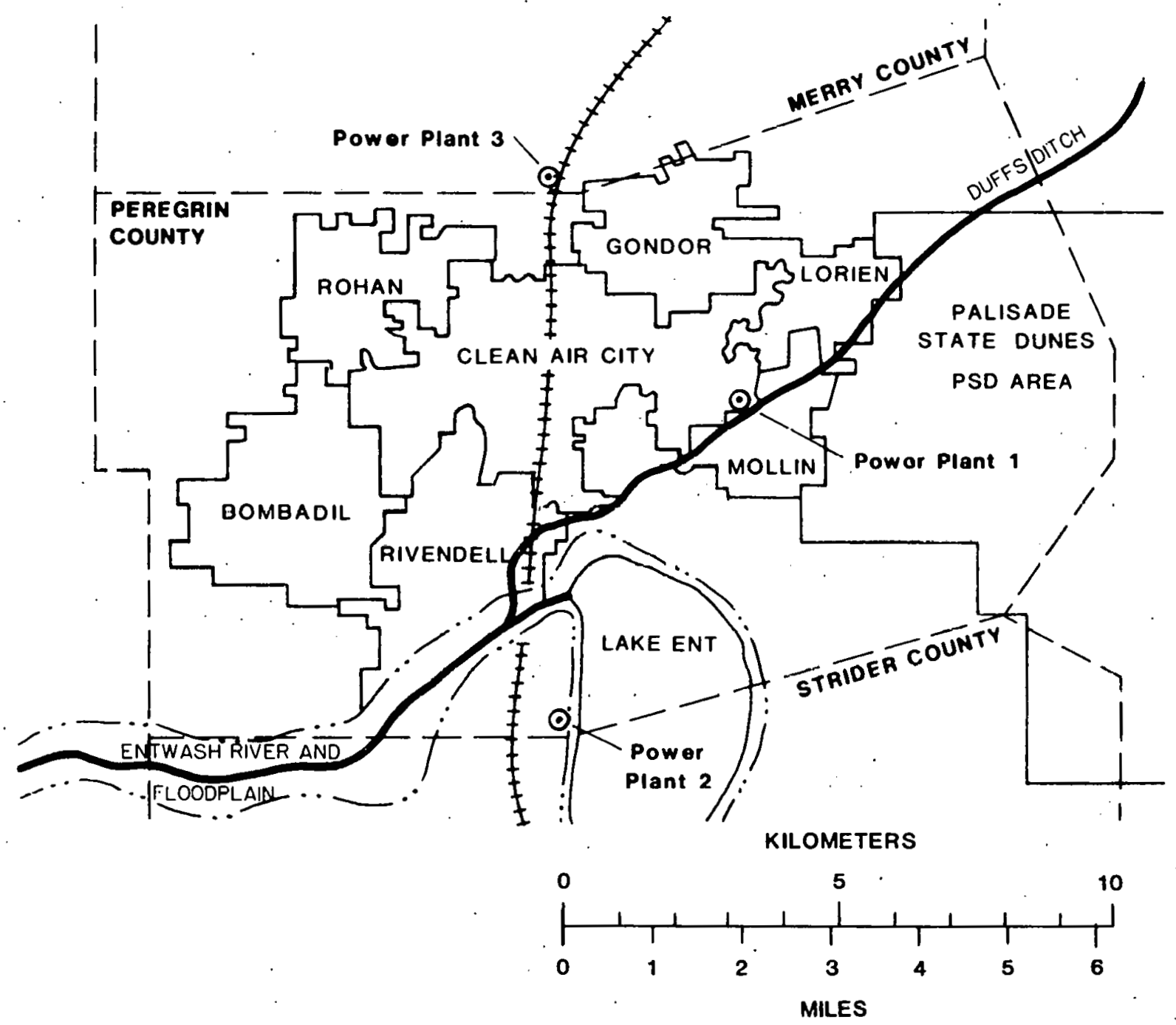

Fig. G.1 Minimal Study-Area Map

political decision which, for the purposes of this discussion is assumed to precede the actual mapping procedure. If such a decision has not in fact been made prior to mapping, boundaries must be determined hefore mapping can proceed very far."

Political Jurisdictions. After the boundaries of the study area have been determined and mapped, the boundaries of each major political jurisdiction must be mapped. These include municipalities and counties.

Developmental Constraints. Next, planners must identify and map those physical features in a study area that could severely restrict or even bar the use of distribution piping for a district heating and cooling system. The following features represent such possibilities. 
- Bodies of water: rivers, lakes, reservoirs, swamps, wetlands, and flood plains of significant land area -- all. of which constitute current restraints in the development of a district heating system.

- Unsuitable terrain: mountains, steeply sloping areas, rock zones, cemeteries, areas of mudslide potential, etc. -- which actually bar development of a district system.

- Open space with a permanent no-development-allowed status: federal and state facilities and local reserves for sensitive environments.

- Other areas that cannot be developed: special local conditions may preclude development on certain parcels of 1 and.

Power Plants. These include electric and thermal generating plants within about 15 miles of a study-area boundary; such plants might be considered thermal sources for a district heating and cooling system and should therefore be shown on the map.

\section{Step 2: Plot a System of $1 \mathrm{~km}$ by $1 \mathrm{~km}$ Grid Squares}

Using Cartesian Coordinates, * Establish the Grid System. Place transparent drawing material over the study-area map prepared in step 1 and locate a point at least $1 \mathrm{~km}$ west $1 \mathrm{~km}$ south of the region's boundary. This point will be your grid origin; record its coordinates as $1,1 * *$ and draw a pair of perpendicular lines through it. (See Fig. G.2.) Now draw a l-km grid system, as shown in Fig. G.3. No more than 450 grid squares with demand data can be used in the DHSM, due to programming constraints. In addition, the 450 squares must be contained within a matrix whose total size is no larger than $32 \mathrm{~km}$ (east-west) by $50 \mathrm{~km}$ (north-south). Larger regions must be reduced in size.

Number the Grid Squares. Each square assigned demand data in the final grid system is to be given an identifying number. The numbering system used

\footnotetext{
*A. system for locating a point in a plane by specifying its distance from two axes ( $x$ and $y$ ) at right angles to each other and intersecting at a point called an origin $(0)$. Any Cartesian-coordinate system (such as state-plan coordinates or Universal l'ransverse Mercator) may be used if its use is well established in the region, if the origin is located at the southwest corner of the study area, and if all locations within the study area have positive $x$ and $y$ coordinates. Systems such as latitude and longitude cannot be used. If every grid square is not precisely $1 \mathrm{~km} \cdot 1 \mathrm{~km}$, then DHSM cost calculations for the transmission, loop, and distribution systems will not be correct.
}

**The first number represents the $x$, or east-west value; the second represents the $y$, or north-south, value. 
for the map in Fig. G.3 is also shown in Fig. G.4. The numbering system is used for identification purposes. To facilitate locating grid squares on the map, they should be numbered from left to right starting on the bottom row of the matrix, then left to right on the row just above the bottom row, and so on. Only squares with demand data need be numbered.

Construct a scenario. In developing scenarios for testing in the DHSM, the grid squares containing the highest thermal demands usually should be included. 'l'hese squares need not be contiguous. Two hypothetical scenarios using the numbered map are shown in Figs. G.4 and Fig. G.5.

Power-plant locations must be specified using the same coordinate system so they $c a n$ be put into the model. These locations must be exactly specified, not rounded to the nearest kilometer.

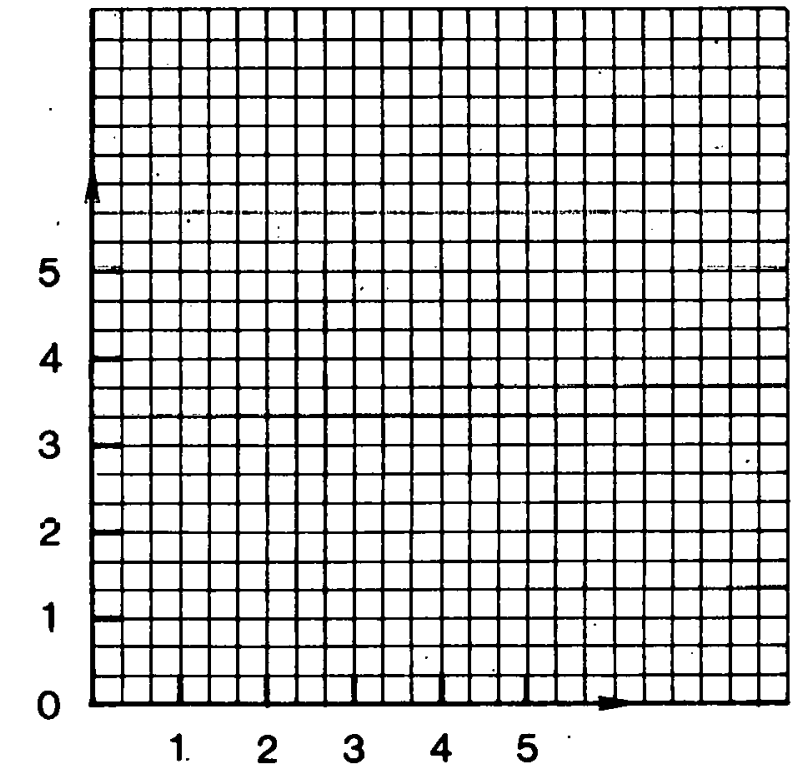

Fig. G.2 Cartesian Coordinates with Which Grid Squares are Superimposed on a SțudyArea map 


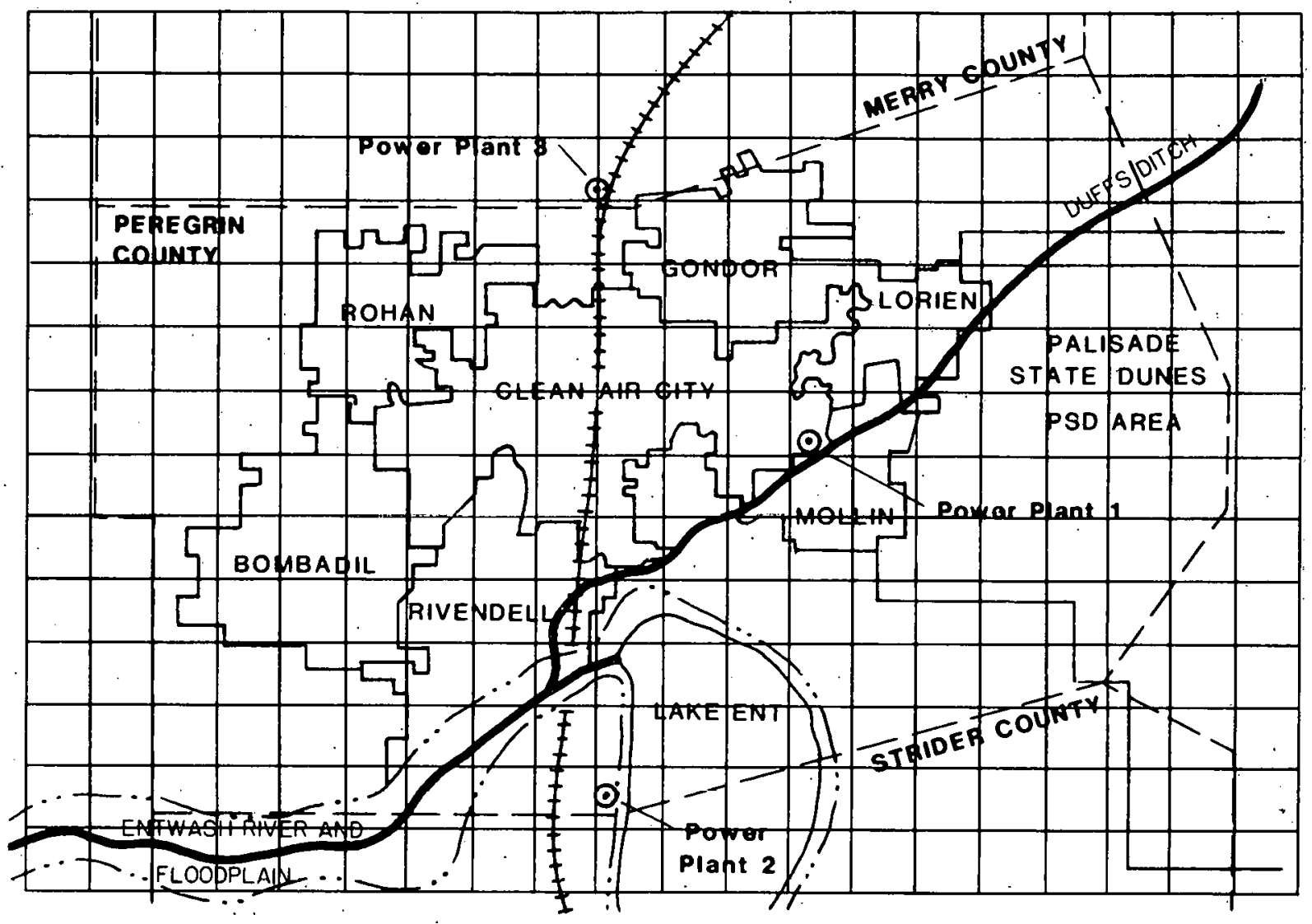

Fig. G.3 A DHSM Grid System Superimposed on a Hypothetical Study-Area Map 


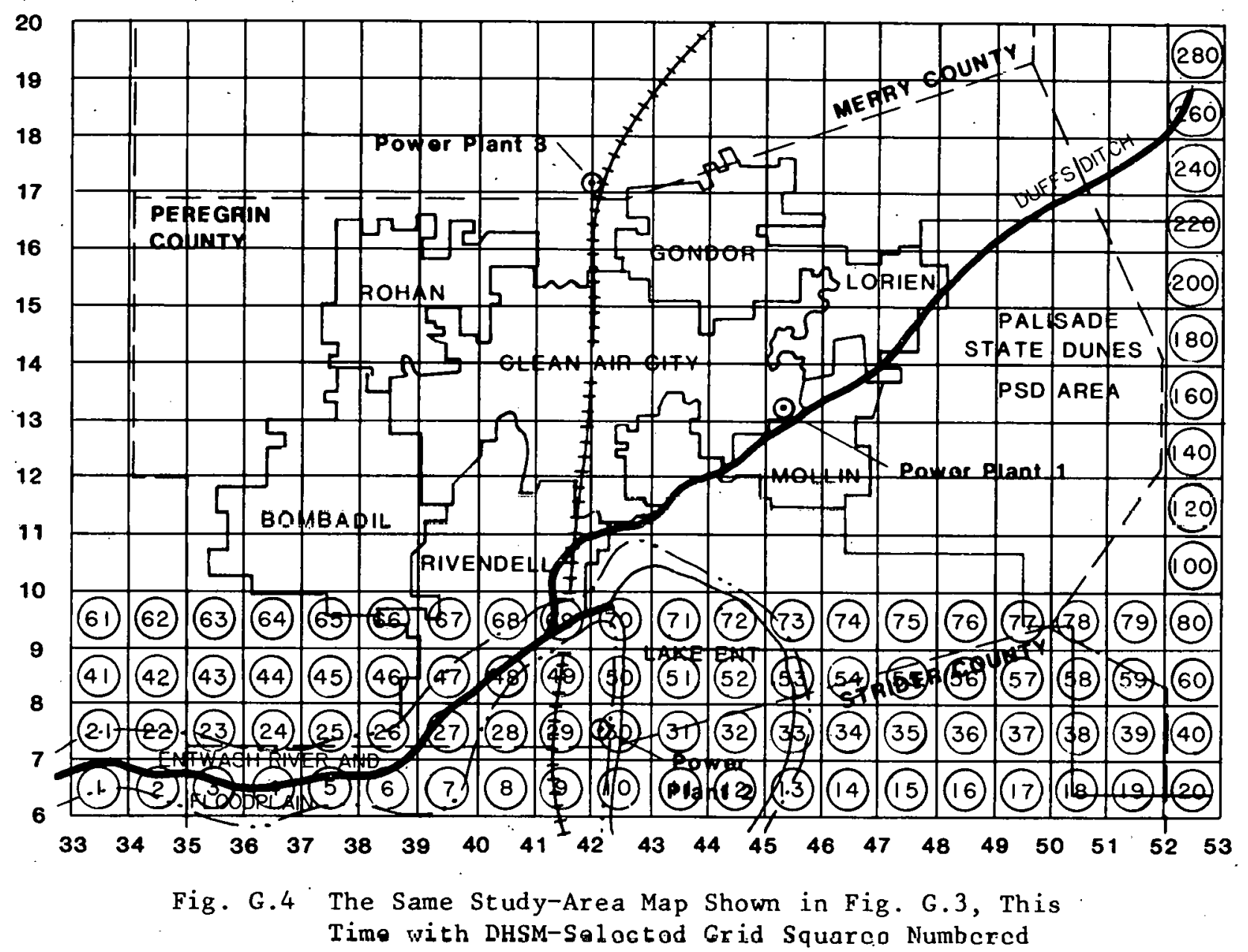




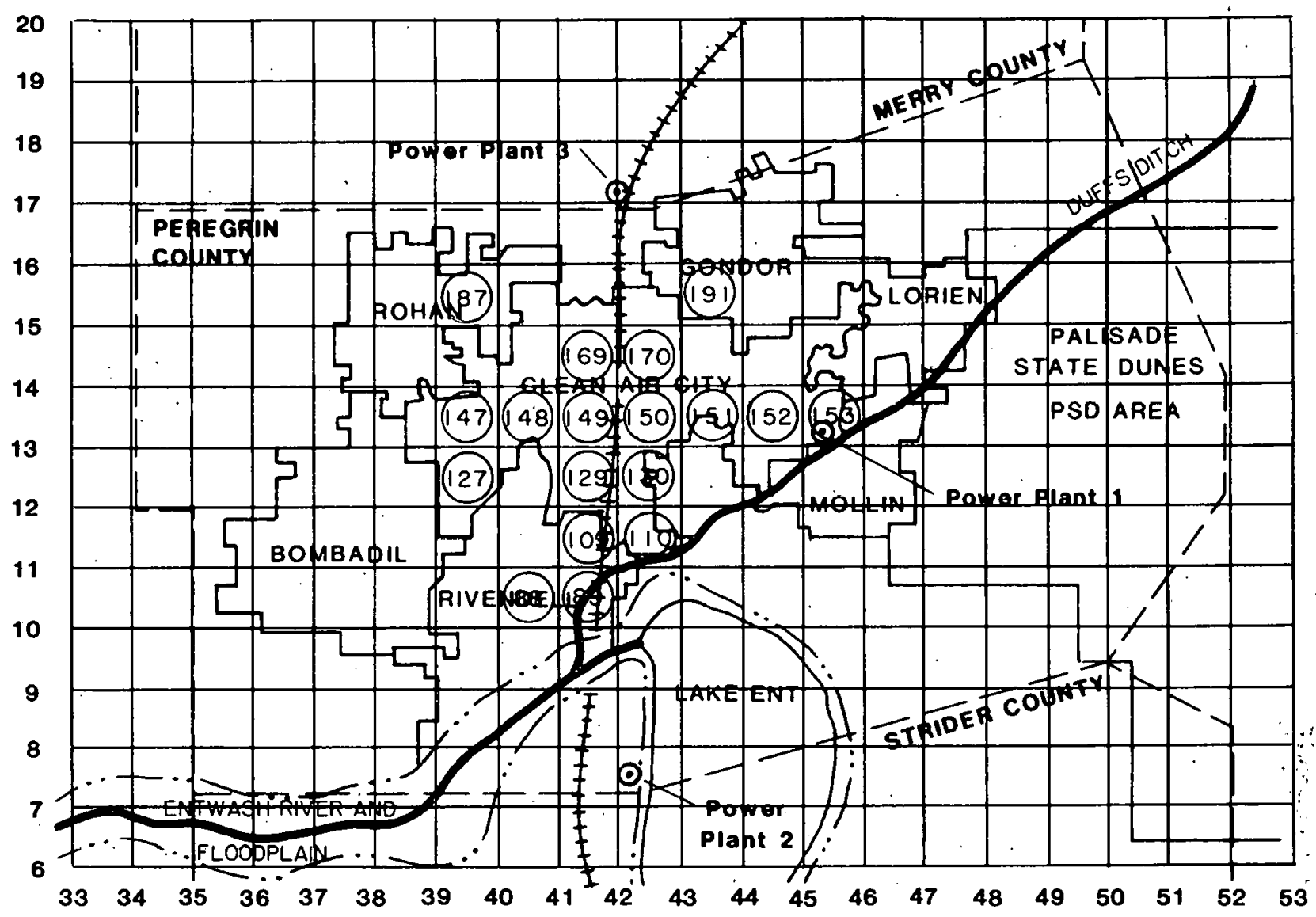

Fig. G.5 The Same Map Shown in Figs. G.3 and G.4, This Time with Other Squares Numbered for Another DHSM Scenario ${ }^{\dagger}$ 
THIS PAGE

WAS INTENTIONALLY

LEFT BLANK 
APPENDIX H

SAMPLE ANNOTATED COMPUTER OUTPUT FROM THE

DISTRICT HEATING STRATEGY MODEL

This appendix depcits and describes parts of a computer output for the DHSM run that was completed for Piqua, Ohio, a city of 20,030 located about 25 $\mathrm{mi}$. north of Dayton. Piqua is in the early stages of building a district heating system. An output of the DHSM is fairly long because there are 31 different page formats, some of which are frequently repeated. Each format contains information useful to the analyst.

Formats identified as "data echoes" show the input data used for the scenario being studied, including all community characteristics and assumptions being tested. Formats identified as "calculation results" show the output data, or numbers generated by the model from information in the data echoes; the DHSM computer program performs the calculations.

\section{H.1 ANNOTATED OUTPUT}

DHSM output is not as formidable as it first appears. The 31 page formats that follow all provide useful data, although some are more useful than others. Table H.1 classifies the pages numbered $1,2,3,4,8,9,10,11,12,13$, $14,19,20$, and 25 as data echoes -- the term describes the function of these pages, repeating the input data. The echoes perform a useful function by simply presenting the data used by the community and ANL for making the run. The choices define the scenario.

The remaining 16 formats represent calculation results and thus provide a wealth of information about the community, scenario, and possible district heating and cooling system. These are also classified in Table H.l according to specific area of output data.

The output is divided into four major groups, each focused on a module in the program. These four groups -- demand, supply, cost, and emissions -- are discussed in Secs. H.2 through H.5.

\section{H.2. DEMAND OUTPUTS}

Formats 5,6 , and 7 show the energy demands for the community as a whole and for grid square subareas within the community. Format 15 (and 27-28 for fuel use) show demand calculations for the area within the scenario. The two major types of demands calculated are peak and annual.

$\therefore \quad$ Peak demands are the maximum quantities of heat needed at any specified time. Generally, peaks are used to calculate the size of equipment needed for the system. In the model, peaks are used to determine the power-plant retrofits required; units are converted to district heating until the peak demand is met. The model uses annual demands to calculate the quantity and cost of fuel needed for the existing situation and for future district heating and cooling. 
A1. $\dot{x}$ co-ordingte (1) of kestern edje of grid $(\mathrm{km}): \ldots$

A2. Wational region number (from map DJFAM1):

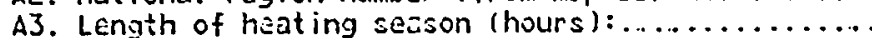

A4. Seasonal heating degree days for the comunity:

A5. Minimuli design temperature for heazing (deg. F):

A6. Hiximuin design temperature for cooling (dag. F):

A7. Hean coiricidant wet tulb temperature (deg. Fl:.

A8. Annual cosling degree day's (see mas JOFAllizi.... 1200

49. Space heating demand factor scal ing(?)-
1. Natural gas -
Residential low density: ............. 1.000
Residential high density: ............. $1.00 n$
Commercial/Institutional: ... ......... 1.000
2. oil -

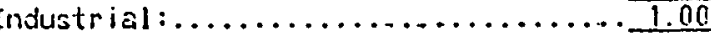
Residential low density: ........... 1.000
Residential hish density:............ 1.0n
Cominercial/Inst itut ional : ........... 1.000
3. Coal

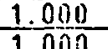
Residential low density: ............ 1.000
Resiciential hi h density. .............
Resiciential high density: .........
Colimercial/Institutional $\ldots \ldots \ldots \ldots \ldots \ldots$
4. Electricity -
Residential low density:............... 1.0no
Residential high density:........... 1.0?n
Cuminercial/Institutional : ........... 1.non
Industrial:
5. Existing district stean systen
Residential low density: ............ 1.000
Residential low density: $\ldots \ldots \ldots \ldots \ldots \ldots, \frac{1.000}{1.000}$
Residential high density: .........
Commercial/Institutional: .................
Industrial

1 Round to nearest whole kilometer.

2 Values of unity are recomended (in ordss to cbtain the default values), unless special local knowledge is available.

PAGE FORMAT 1

DATA ECHO

- Describing climatic data input from $A N L$.

- Describing derand data input from the Community Demand Data Sheet.

- Only one page cf output will have this format. 
A:0. Hot water demand scaling\{ 3 ) by building type Residential low density:............. 1.000 Residential high density:........... 1.000 Commercial/Institutional:.......... 1.0no

A:1. Cooling deriarid scalingi 4 i-

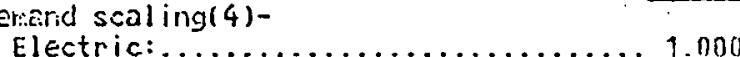

Residential low density heating \& h.w. :....... $1.00 n$

Residential high density heating \& h.w. ....... t. 000

Comnercial/Institutional heating \& h.w.:..... 1.nn

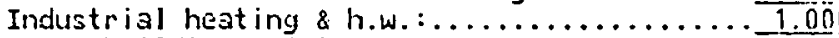

Large building cool ing: ...........

A 13 . Industrial process heat damand scale factor $(6): \ldots 1.000$

A:4. Fuel mix scaling -

1. Hatural gas -

Residential lo: dens ity: $\ldots \ldots \ldots \ldots \ldots \ldots \frac{1}{1} .0 n n$
Residertial high density: $\ldots \ldots \ldots \ldots \ldots$ Coimercial/Institutional: ...........

2. Dil -

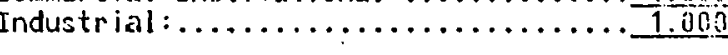

Residential lo' density:..........1.000 Residential hish density:.......... 1.000 Colmercial/Institutional : .......... 1.000

3. Coal $\cdots \cdots \frac{1.30}{1.000}$

Residential low density:.............000 Residential high density:........... 1.000 Cobtiercial/Institutional: . . . . . . . . 1.00 Industrial :...................

4. Electricity -

Residential low density:............. 1.n00 Reciclential high density:........... 1.00 Contercial/Institutionai : . . . . . . . .

5. Existing district steam system -

Residential low density: ........... 1.000 Residential hish density: .......... Colmercial/Iristitutional: ..........1.0?0 Insustrial. ..................... 1.060

3 values of unity are recormended (in order to obtain the default values), unless special local kinualedge is available.

\section{4 as above}

5 as above

6 as above

PAGE FORMAT 2

DATA ECHO

- Describing data input from the Community Data Base Sheet.

- Only one page of output will have this format. 
Form DDFBC

Name of Community:

PIQUA

Record

B1. $X$ co-ordinate of southwest corner of gridsquare

to the nearest kilomoter:

B2. $Y$ co-ordinate of southwest corner of gridsquare

to the nearest kiloməter:...................

83. Floor space by building type (in millions of square feet) Residential low density heating \& hot water:..... 4730 Residential high density heating \& hot water: ...7.700 $\overline{7}-02$ Commercial/Institutional heating $\&$ hot water: . ... 1460

Industrial heating \& hot water $\ldots \ldots \ldots \ldots \ldots \ldots . .1650$

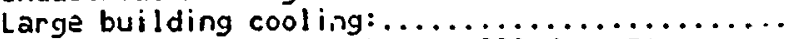

84. Industrial low tempenature $(<200$ deg. F) process

hast requirerients which may be thel by a district

heating system in units of billion Btu/year: ....11.83

B5. Equivalent stack he $i$ ght for emissions (meters):...

Record $C$

1. Fuel mix by building and end-use category (1)-

1. Residential low and high density - Heating only -

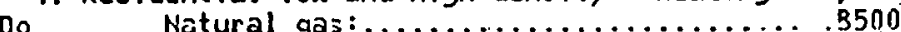

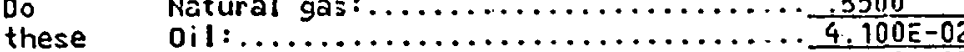

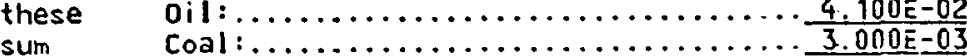

sum $\quad$ Electricity............................

unity? Existing district steam:..............

2. Residential lo's and high density - Hot water only

Do Natural gas $\ldots \ldots \ldots \ldots \ldots \ldots \ldots \ldots \ldots \ldots . .5500$

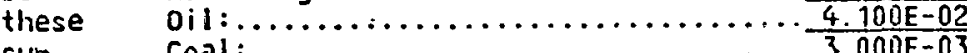

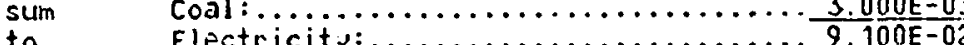

unity? Existing district stean: ............

3. Commercial/Institutional - Heating and ho $\div$ water -

Do liatural gas $\ldots \ldots \ldots \ldots \ldots \ldots \ldots \ldots \ldots \ldots \ldots . . . \ldots 10$

these $\quad 0$ il :

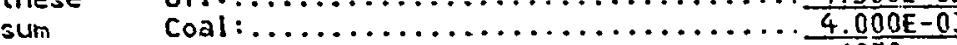

Electricity:.......................1030

unity? Existing district steam:.......... 2.700E-02 4. Industrial - Heating and hot water -

Do Matural gas:..................4090

these 0 il

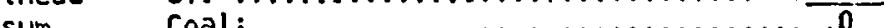

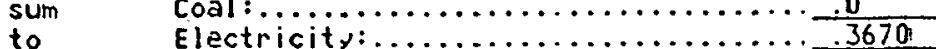

unity? Existing district steain:...........

1 The sum over fuel types in a given category should equal unity.
PAGE FORMAT 3

DATA ECHO

- Describing data input from the community that is used tc determine heat demands for one grid square; from the Grid Square Demand Data Sheet.

- There is one fage of output like this for each grid square on the community's grid map.

- The remaining pages like this one for Piqua have been removed to shorten this description. The Piqua study included 54 grid squares. 
C2. Air canditioning mix by floorspace fractions $(2)-$

$$
\begin{aligned}
& \text { Elestricity: } \ldots \ldots \ldots \ldots \ldots \ldots \ldots \ldots \ldots \ldots .1,000 \\
& \text { Existing district steain: } \ldots \ldots \ldots \ldots \ldots .0 \\
& \hline
\end{aligned}
$$

c3. Fraction( 3 ) of industrial process heat final demand met by various fuels -

Do

these

Natural gas:................6470

.2280

sum

..................

unity?

Existing district stean:....

\section{PAGE FORMAT 4}

DATA ECHO

- Describing community data input used to determine heat demands for one grid square; from the Grid Square Demand Data Sheet.

- This page format appears only for grid squares the community has indicated demand large-building air conditioning or industrial process heat.

- Again, many pages similar to this one appear in the Piqua example; for purposes of brevity, only one is shown here. 
OISTRICT HEATIHG -.- DEMAHD - - CITY: PITUI

PAGE FORMAT 5
CALCULATION RESULTS (desCTIbed belGW!

19 RESIDEMTIAL LOH' DENSITY HEATIHG \& HOT HATER

19 RESIDEHTIAL LOH' DENSITY HEATILG \& HOT HATE? RESIDEHITIAL HIEH DEIISITY HEATING \& HDT WATER COFHERCIAL/INSTITUTIGMAL HEATIHG \& HQT HATER IRDUSTRIAL HEATIHG \& HOT HATER LARGE BUILDIHG COOLING

IHDUSTRIAL FROCESS

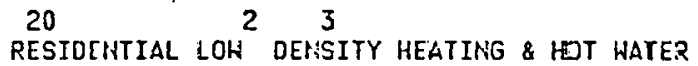
RESIDENTIAL HIGH DENSITY HEATIMG \& HDT HATEZ COHIIERCIAL/INSTITUTIOHAL HEATIIG \& WET WAIER INDUSTRIAL

LARGE BUILDIYAG COOLING

INDUSTRIAL FRCCESS

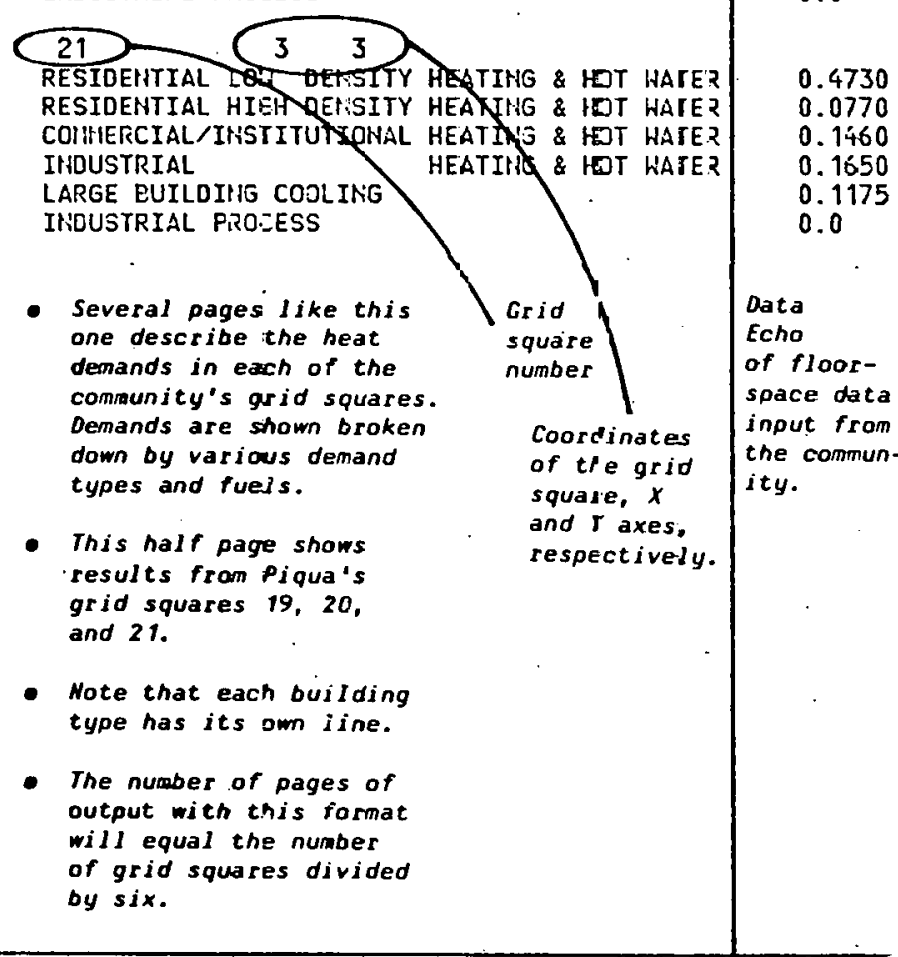

\begin{tabular}{|c|c|c|c|c|c|c|c|c|c|c|c|}
\hline \multirow[t]{2}{*}{$\begin{array}{l}\text { FLOORSPACE } \\
\text { MILLIOISSQFT }\end{array}$} & \multicolumn{5}{|c|}{$\begin{array}{l}\text { FIHAL DEMAIIDS } \\
\text { BILLION BTL } / Y\end{array}$} & \multicolumn{2}{|c|}{$\begin{array}{l}\text { PEAK DEIMAIIC } \\
\text { T THERHAL :IH: }\end{array}$} & \multicolumn{3}{|c|}{$\begin{array}{l}\text { ELECTRIC CREOITS } \\
\text { ENERGY CAPACITY(MW) }\end{array}$} & \multirow{2}{*}{$\begin{array}{l}\text { HOH.!'ATRR } \\
\text { FIH.EEH } \\
\text { B.UTU/Y }\end{array}$} \\
\hline & GAS & CIL & COAL & LECT. & DSS. & HWTR. & SJIF. & & HNTR. & SUkir. & \\
\hline $\begin{array}{l}0.0110 \\
0.0 \\
0.0070 \\
0.0200 \\
0.0 \\
0.0\end{array}$ & $\begin{array}{l}0.85 \\
0.0 \\
0.40 \\
0.33 \\
0.0 \\
0.91\end{array}$ & $\begin{array}{l}0.04 \\
0.0 \\
0.01 \\
0.14 \\
0.0 \\
0.42\end{array}$ & $\begin{array}{l}0.00 \\
0.0 \\
0.00 \\
0.0 \\
0.0 \\
0.0\end{array}$ & $\begin{array}{l}0.05 \\
0.0 \\
0.02 \\
0.11 \\
0.0 \\
0.0\end{array}$ & $\begin{array}{l}0.01 \\
0.0 \\
0.01 \\
0.05 \\
0.0 \\
0.08\end{array}$ & $\begin{array}{l}0.10 \\
0.0 \\
0.05 \\
0.08 \\
0.0 \\
0.05\end{array}$ & $\begin{array}{l}3.01 \\
3.0 \\
3.00 \\
3.00 \\
3.0 \\
3.65\end{array}$ & $\begin{array}{l}0.02 \\
0.0 \\
0.01 \\
0.03 \\
0.0 \\
0.0\end{array}$ & $\begin{array}{l}0.01 \\
0.0 \\
0.00 \\
0.01 \\
0.0 \\
0.0\end{array}$ & $\begin{array}{l}0.00 \\
0.0 \\
0.00 \\
0.00 \\
0.0 \\
0.0\end{array}$ & $\begin{array}{l}0.05 \\
0.0 \\
0.01 \\
0.01 \\
0.0 \\
0.47\end{array}$ \\
\hline $\begin{array}{l}0.0130 \\
0.0 \\
0.0200 \\
0.0980 \\
0.0 \\
0.0\end{array}$ & $\begin{array}{l}1.00 \\
0.0 \\
1.15 \\
1.86 \\
0.0 \\
4.58\end{array}$ & $\begin{array}{l}0.05 \\
0.0 \\
0.02 \\
0.70 \\
0.0 \\
2.11\end{array}$ & $\begin{array}{l}0.00 \\
0.0 \\
0.01 \\
0.0 \\
0.0 \\
0.0\end{array}$ & $\begin{array}{l}0.06 \\
0.0 \\
0.05 \\
0.52 \\
0.0 \\
0.0\end{array}$ & $\begin{array}{l}0.02 \\
0.0 \\
0.04 \\
0.25 \\
0.0 \\
0.39\end{array}$ & $\begin{array}{l}0.12 \\
0.0 \\
0.14 \\
0.33 \\
0.0 \\
0.24\end{array}$ & $\begin{array}{l}3.61 \\
3.6 \\
3.60 \\
3.01 \\
3.6 \\
3.24\end{array}$ & $\begin{array}{l}0.02 \\
0.0 \\
0.09 \\
0.17 \\
0.0 \\
0.0\end{array}$ & $\begin{array}{l}0.01 \\
0.0 \\
0.01 \\
0.06 \\
0.0 \\
0.0\end{array}$ & $\begin{array}{l}0.00 \\
0.0 \\
0.00 \\
0.00 \\
0.0 \\
0.0 \\
.\end{array}$ & $\begin{array}{l}0.05 \\
0.0 \\
0.02 \\
0.06 \\
0.0 \\
2.34\end{array}$ \\
\hline $\begin{array}{l}0.4730 \\
0.0770 \\
0.1460 \\
0.1650 \\
0.1175 \\
0.0\end{array}$ & $\begin{array}{l}36.37 \\
3.77 \\
8.38 \\
3.14 \\
0.10 \\
7.66\end{array}$ & $\begin{array}{l}1.70 \\
0.18 \\
0.12 \\
1.18 \\
0.0 \\
3.53\end{array}$ & $\begin{array}{l}0.13 \\
0.01 \\
0.04 \\
0.0 \\
0.0 \\
0.0\end{array}$ & $\begin{array}{l}2.31 \\
0.25 \\
0.33 \\
0.83 \\
5.34 \\
0.0\end{array}$ & $\begin{array}{l}0.60 \\
0.10 \\
0.29 \\
-0.42 \\
0.0 \\
0.65\end{array}$ & $\begin{array}{l}4.36 \\
0.42 \\
1.05 \\
0.65 \\
0.0 \\
0.40\end{array}$ & $\begin{array}{l}3.22 \\
3 . c 4 \\
3 . c 2 \\
3 . c 1 \\
1 . c 0 \\
3.50\end{array}$ & $\begin{array}{l}0.75 \\
0.03 \\
0.11 \\
0.29 \\
0.83 \\
0.0\end{array}$ & $\begin{array}{l}0.25 \\
0.02 \\
0.04 \\
0.11 \\
0.0 \\
0.0\end{array}$ & $\begin{array}{l}0.02 \\
0.00 \\
0.00 \\
0.00 \\
0.63 \\
0.0 \\
.\end{array}$ & $\begin{array}{l}2.19 \\
0.35 \\
0.17 \\
0.11 \\
5.34 \\
3.92\end{array}$ \\
\hline $\begin{array}{l}\text { Data } \\
\text { Echo } \\
\text { of floor- } \\
\text { space data } \\
\text { input from } \\
\text { the commun- } \\
\text { ity. }\end{array}$ & & 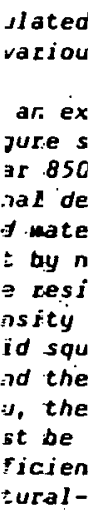 & $\begin{array}{l}\text { annual } \\
\text { fuel } \\
\text { mple. } \\
\text { ows th } \\
\text { millio } \\
\text { and fo } \\
\text { neati } \\
\text { tural } \\
\text { ential } \\
\text { tructe } \\
\text { re } 19 . \\
\text { fuel } \\
850 \text { mi } \\
\text { ivideo } \\
\text { y fact } \\
\text { as equ }\end{array}$ & $\begin{array}{l}\text { demands } \\
\text { ypes. } \\
\text { his } \\
\text { teach } \\
\text { Btu of } \\
\text { space } \\
g \text { is } \\
\text { as in } \\
\text { law- } \\
\text { es of } \\
\text { To } \\
\text { nand in } \\
\text { lian } \\
\text { by the } \\
\text { t for } \\
\text { oment. }\end{array}$ & & $\begin{array}{l}\text { Summer } \\
\text { winte } \\
\text { therma } \\
\text { demano } \\
\text { the ma } \\
\text { heat } \\
\text { quires } \\
\text { any on } \\
\text { point } \\
\text { time } \\
\text { linsta } \\
\text { eous }\end{array}$ & $\begin{array}{l}\text { and } \\
\text { peat } \\
\text { s, } \\
\text { ximun } \\
\text { e- } \\
\text { at } \\
\text { in } \\
\text { itan- } \\
\text { eakl. }\end{array}$ & $\begin{array}{l}\text { Elect } \\
\text { curre } \\
\text { heati } \\
\text { ments } \\
\text { heat } \\
\text { will, } \\
\text { elimi } \\
\text { for } \\
\text { Total } \\
\text { ing } \\
\text { gigar } \\
\text { year; } \\
\text { in se } \\
\text { ties } \\
\text { megan }\end{array}$ & $\begin{array}{l}\text { ric cap } \\
\text { ntly se } \\
\text { ng requ } \\
\text { oist } \\
\text { ng/cool } \\
\text { in eff } \\
\text { nate th } \\
\text { his cap } \\
\text { annual } \\
\text { re show } \\
\text { att-hou } \\
\text { reduct } \\
\text { asonal } \\
\text { are sho } \\
\text { atts. }\end{array}$ & $\begin{array}{l}\text { city } \\
\text { ving } \\
\text { re- } \\
\text { ict } \\
\text { ng } \\
c t \text {, } \\
\text { need } \\
\text { city. } \\
\text { sav- } \\
\text { in } \\
\text { s per } \\
\text { ons } \\
\text { apaci- } \\
\text { in in }\end{array}$ & $\begin{array}{l}\text { The nonwinter } \\
\text { final demand } \\
\text { (billion Btu per } \\
\text { yr) shows the } \\
\text { amount of heat } \\
\text { required by the } \\
\text { city during non- } \\
\text { winter hours; use- } \\
\text { ful as a gauge of } \\
\text { year-round demand. }\end{array}$ \\
\hline
\end{tabular}


DISTRICT HEATING --- DEMAND --- CITY: PIQ:JA

\begin{tabular}{|c|c|c|c|c|c|c|c|c|c|c|c|}
\hline $\begin{array}{l}\text { PAGE FORMAT } 6 \\
\text { CALCULATION RESULIS (see }\end{array}$ & below) & DEHAS:ID & $\begin{array}{l}\text { FACTORS } \\
\text { GAS }\end{array}$ & S, 1000 & $\begin{array}{l}\text { O BTU/ } \\
\text { CE HEA } \\
\text { COAL }\end{array}$ & $\begin{array}{l}\text { CSOFT } \\
\text { ATIYSO } \\
\text { ELEC }\end{array}$ & & $\begin{array}{r}\text { HOT } \\
\text { HATER }\end{array}$ & $\begin{array}{l}\text { LAF.UE } \\
\text { ELEC }\end{array}$ & $\begin{array}{l}\text { BUILDIHIG COOLIHG } \\
\text { DSS. }\end{array}$ & $\begin{array}{l}\text { DATA ECHO: demand- } \\
\text { factor input from }\end{array}$ \\
\hline $\begin{array}{l}\text { RESIDENTIAL LOW DE.VSITY } \\
\text { RESIDEITIAL HIGH DE ISITY } \\
\text { COH IERCIAL/IHSSTITUTIOHAL } \\
\text { IND.JSTRIAL }\end{array}$ & $\begin{array}{l}\text { HEATIHG \& HOT } \\
\text { HEATIHIG \& HOT } \\
\text { HEATIHI \& HOT } \\
\text { HEATIIIG \& HOT }\end{array}$ & $\begin{array}{ll}T & \text { HATER } \\
T & \text { WATER } \\
T & \text { HATER } \\
T & \text { HAT } \equiv R\end{array}$ & $\begin{array}{l}76.5 \\
43.5 \\
63.9 \\
44.5\end{array}$ & $\begin{array}{l}73.5 \\
43.5 \\
51.3 \\
35.8\end{array}$ & $\begin{array}{l}75.5 \\
43.5 \\
62.9 \\
43.5\end{array}$ & $\begin{array}{l}35.7 \\
21.3 \\
19.4 \\
12.6\end{array}$ & $\begin{array}{l}70.6 \\
70.6 \\
70.6 \\
70.6\end{array}$ & $\begin{array}{r}14.0 \\
14.0 \\
3.6 \\
2.0\end{array}$ & 45.5 & 45.5 & $\begin{array}{l}\text { community or, if } \\
\text { defaulted, inserted } \\
\text { by the model. }\end{array}$ \\
\hline
\end{tabular}

SUIBIARY RESULTS FOR THE CITY OF PIQUA

FLOORSPACE
MILLIOHSQFT

$\begin{array}{lrr}\text { IORSPACE } & & \text { FINAL } \\ & & \text { BILLIO } \\ & \text { GAS } & \text { OIL } \\ & & \\ 9.962 & 765.9 & 35.8 \\ 0.435 & 21.3 & 1.0 \\ 3.231 & 222.8 & 3.2 \\ 3.293 & 62.6 & 23.5 \\ 3.658 & 0.0 & 0.0 \\ 0.0 & 185.2 & 85.3\end{array}$

PEAK DEMAND

(THERHAL IH!) EMERCTRIC CEEOITS POCIH!ITR

HITR SUIR. ENEROY CAPACITY(IHW) FIH:.DEH

RESIDENTIAL LOH DEVISITY HEATING \& HOT WATER RESICENTIAL HIGH DENSITY HEATIH'G \& HOT HATER COIIIERCIAL/INSTITUTIONAL HEATIH'́ \& HOT HATER INDIJSTRIAL HEATIHE \& HOT WATER

AR:JE BUILDING COOLING

IYIDUSTRIAL PROCESS

CALCULATION RESUITS:

COAL ELECT.

$\begin{array}{rrrr}2.7 & 48.7 & 12.6 & 91.8 \\ 0.1 & 1.4 & 0.6 & 2.4 \\ 1.0 & 8.8 & 7.8 & 23.0 \\ 0.0 & 17.6 & 8.4 & 12.9 \\ 0.0 & 168.1 & 0.0 & 0.0 \\ 0.0 & 0.0 & 15.7 & 9.6\end{array}$

$\begin{array}{lll}21.270 & 1257.9 & 148.8\end{array}$

3.8244 .6

$45.1 \quad 144.7$

than demands and other
than grid square.

data (as in FORMAT 5) but for the entire community rather

liNTR. SU:iR.

than each grid square. Explanations of column headings may be. found on FORMAT 5.

THE FOLI.C'AÜHG BUILDIMG TYFES ARE INCLUDED IN THE PESL' UËHAHD MAP:

RESTOENTIAL LOH DEHSITY HEATIHG \& HOT HATER

RESLOEHTIAL. HIGH DEHSITY HEATING \& HOT WAT

COI:HERCIAL/IISTITUTIONAL HEATINE \& HOT MATER

IHIDUSTRIAL HEATIHG \& HOT HATER

LARIJE RUILDING COOLING

The community's peak demand map is shown in FORMAT

7. This provides a list of the user-specified

IHEUSTRIAL FROCESS

THE ARITHMETIC AVERAGE PEAK DEMAND OVER AL: 54 GRIDSQUARES IS 2.7 THERMAL MEgalHATTS.

IN FACH GRIESQUARE ON THE MAP, THE UPPER FIGURE IS THE CRIDSQUARE MLIMISER, AHD THE LOIJER IS PEAK DEMAHD IM MEGAHATTS.

There will be only one page of output with this format. 
DISTRICT HEATING --. DEMALN --- CITY: PIEUA

\begin{tabular}{|c|c|c|c|c|c|c|c|c|}
\hline$\left|\begin{array}{r}1 \\
46 \\
0\end{array}\right|$ & $\begin{array}{r}2 \\
471 \\
01\end{array}$ & $\begin{array}{r}381 \\
01\end{array}$ & $\begin{array}{r}491 \\
11\end{array}$ & $\begin{array}{r}501 \\
01\end{array}$ & 511 & $521_{11}^{8}$ & $\begin{array}{r}8 \\
531 \\
21\end{array}$ & $\begin{array}{r}54 \\
1\end{array}$ \\
\hline $\begin{array}{r}371 \\
01\end{array}$ & $\begin{array}{r}381 \\
11\end{array}$ & $\begin{array}{r}--t \\
391 \\
31\end{array}$ & 401 & $\begin{array}{r}411 \\
91\end{array}$ & 421 & 431 & $\begin{array}{r}44 \\
11\end{array}$ & $\begin{array}{c}45 \\
0\end{array}$ \\
\hline $\begin{array}{r}231 \\
01\end{array}$ & $\begin{array}{r}291 \\
31\end{array}$ & $\begin{array}{r}301 \\
71\end{array}$ & $\begin{array}{l}311 \\
101\end{array}$ & $\begin{array}{l}321 \\
231\end{array}$ & $\begin{array}{l}331 \\
101\end{array}$ & $\begin{array}{r}341 \\
21\end{array}$ & $\begin{array}{r}35 \\
21\end{array}$ & $\begin{array}{c}--+ \\
36 \\
0\end{array}$ \\
\hline $\begin{array}{r}191 \\
0 \mid\end{array}$ & 201 & $\begin{array}{r}211 \\
71\end{array}$ & $22 \mid$ & 231 & $\begin{array}{r}24 \mid \\
61\end{array}$ & $25 \mid$ & 261 & $\begin{array}{c}27 \\
0\end{array}$ \\
\hline $\begin{aligned} 10 ! \\
01\end{aligned}$ & $\begin{array}{r}11 \\
01\end{array}$ & $\begin{array}{r}12 \\
51\end{array}$ & $\begin{array}{r}131 \\
21\end{array}$ & $\begin{array}{r}14 \mid \\
51\end{array}$ & $\begin{array}{r}15 ! \\
1 \mid\end{array}$ & $\begin{array}{r}161 \\
0 \mid\end{array}$ & $\begin{array}{r}17 \mid \\
0\end{array}$ & $\begin{array}{c}18 \\
0\end{array}$ \\
\hline$\left|\begin{array}{l}11 \\
0\end{array}\right|$ & $\begin{array}{l}21 \\
01\end{array}$ & $\begin{array}{l}3 ! \\
0 \mid\end{array}$ & $\begin{array}{l}41 \\
01\end{array}$ & $\begin{array}{l}51 \\
01\end{array}$ & $\begin{array}{l}61 \\
01\end{array}$ & $\begin{array}{l}71 \\
01\end{array}$ & $\begin{array}{l}81 \\
01\end{array}$ & 9 \\
\hline
\end{tabular}

PAGE FORMAT 7

\section{CALCULATION RESULTS:}

- Peak demand map, showing coorcinates and demands per square kilometer; upper figure is grid-square number, lower is its peak demand in megawatts.

- The densest peak demands are.in the central city, with a surrounding area of fairly high demands.

- Only one page of output will have this 


\section{Form SOFA}

Hiame of Community: PIQIJA

Scenar io naire ( 8 character code ): _. _ HS 0 S _-

\section{Record A}

A1. Will all available gi id squares las defined

in forms DDFBC be used in this scenario?

(Enter $T$ for true, $F$ for false.) $\ldots \ldots \ldots \ldots \ldots \ldots \ldots \ldots \ldots$

If answer to above is $F$, attach form SDFB.

A2. Sectors to be included in this scenario -

( $T$ if to be included, $F$ otherwise)

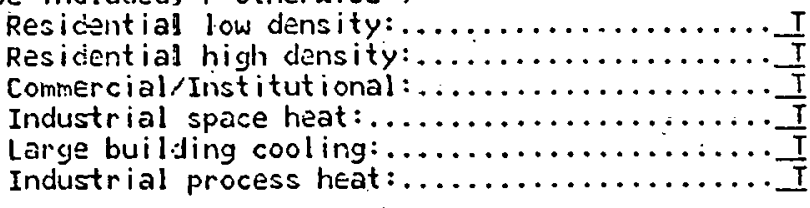

A3. District heating costing( 1) (use "1" - low):........

A4. Fraction of electrical replacenent costs

due to district heating system:.............5000

Note:

All escalation and irflation rates are expressed

as decimal fractions, not sercent.

45. Real escalatior rate for electricity:......... 1.000E-02

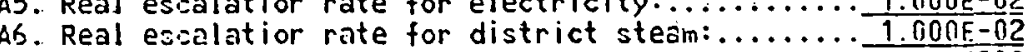

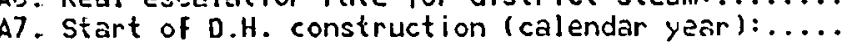

A8. In-service year for district heating system:....

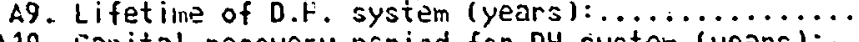

A10. Cepital recovery period for DH system (years): .

A11. Escalation rate for fuels -

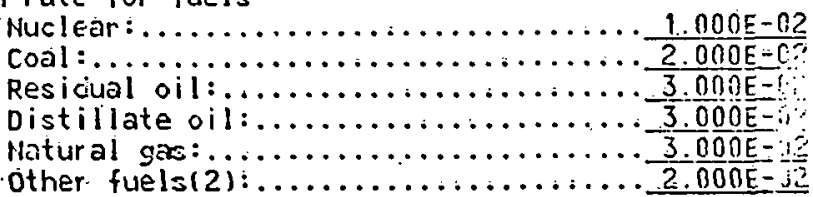

1 selects certain costing defaults.

2 iother fuels" refers to any significant fuel. not alreáli; covered under the preceding fuel categories.

\section{PAGE FORMAT 8}

\section{DATA ECHO}

- Explaining the scenario under study from the Scenario Definition Sheet, with data input from community and ANL.

- Only one page of output will have this format. 
A12. Escalation rate for $08 M$ costs: .............. 5.000E-0

113. Escalation rate for capital costs: .............

A14. Discount rate for present value calculations: .... $1.000 E-02$

$\frac{1.000 E-02}{7.000 E-02}$

A16. Ut ility pre-tax rate of return: ................

A16. Utility pre-tax. rate of return: $: \ldots \ldots$

17. Utility A.F.C. rate (for capitali

$8.000 \mathrm{E}-02$

A18. Cost ceiling ( $\$$ /

for flants converted to district heat ing:......20.00.

A19. Reserve margin (fraction of thermal peak):

\section{PAGE FORMAT 9}

DATA ECHO

- Showing a continuation of economic assumptions governing the scenario; from the Scenaria Definition Sheet, with input from community and $A N L^{\prime}$.

- Only.one page of output will have this format. 
Nane of -Cominunity: preua

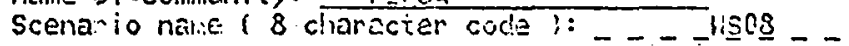

This form is requireri if and soly if question SDFA.A.1 :Is answered "false".

Recorel $\mathrm{B}$

Q1. Number of gridsquares to be included

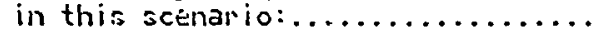

B2. List gridsquare numbers to be incluced in

this scenario. (Refer to deriand input or

deirand output mais for nurbers

orsier listed is not oritical.)

$\begin{array}{llllllllll}12 & 14 & 21 & 22 & 23 & 24 & 30 & 31 & 32 & 33 \\ 40 & 41 & & & & & & & \end{array}$


New baseload bo iler definition

Name of Community: PJQUA

Scenario name ( 8 character code ): _ _ HS0.3 _

Record $C$

C1. Boiler fuel typel 1) code $\ldots \ldots \ldots \ldots \ldots \ldots \ldots \ldots \ldots \ldots \ldots$.

C2. Plant co-ordinjtes(2)

$X$ co-ordinate $(\mathrm{km}$ units $): \ldots \ldots \ldots \ldots \ldots 6.100$

$Y$ co-ordinate $(\mathrm{km}$ units):

c3. Fuel price(3) (s/Mlibtu):...

C4. Thermal heat rate (MBtw/klh):............306

C5. New Boiler cost (Lo's) $(\$ / k \mid 1)$ :

C6. Nan Boiler Cost (High) (s/kH) .......

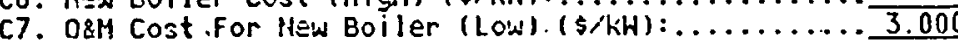

C8. $02 M$ Cost For New Boiler $(\mathrm{High})(\$ / \mathrm{kH}) \ldots \ldots \ldots \ldots \ldots$

Record D (Required if SDFCD.C1 $=2,3$,or 4.)

01 . Weight percent sulfur in fuel:............... 1.00C

02. If SDFCD $C 1=2$, then enter

weight percent ash in fuel :
PAGE FORMAT 11

DATA ECHO

- Describing new boiler location and other parameters; irput from ANL.

- One page of cutput will have this format because only one new baselpad boiler may be used in the model.

- The reason far specifying a new baseload boiler is to enable the model to add new capacity to service all the demand specified in the service district boundary if a station's capacity would otherwise be too low.

1 Codes are : 1 - nuclear (not available),

$$
\begin{aligned}
& 2 \text { - coal, } \\
& 3 \text { - residual oil, } \\
& 4 \text { - distillate oil, and } \\
& 5 \text { - natural gas. }
\end{aligned}
$$

2 Plant location in kilometers.

These values should not be rounded to the

nearest kilometer.

31980 dollars. 


\section{Form SIIPE}

liame of Community: prous

Scenario code:

Ilame of station: PUPS1

Recorde

E1. Station code name (limit 8 characters):......... 'PHFS1 '

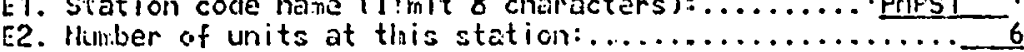

E3. Station co-ordinates!11

E3. Station co-ordinaiesil1 -

$x$ co-ordinate $(\mathrm{km}$ units $): \ldots \ldots \ldots \ldots \ldots 6.1110$

$\hat{y}$ co-ordinate $(\mathrm{km}$ units $): \ldots \ldots \ldots \ldots \ldots \ldots \ldots . . \ldots \ldots \ldots$

1 Plant location in kilometers.

These values should not be rounded to the nearest kilometer.
PAGE FORMAT 12

\section{DATA ECHO}

- Describing an electric generating station that may provide heat to the district heating and cooling system; from the Electric Generating Station Data Sheet.

- There.will be several pages of output with FORMAT 12, one for each electric generating. station being considered in the community. One FORMAT 12 will

precede a number of FORMAT 13s, the FORMAT 12 page describing the whole station and the FORMAT 13 pages describing the units within the station. 


\section{Form SDFFG}

Name of Community: PIQUA

Scenario: HSO8

station code: PHPS

Nare of unit: STG

Record $F$

F1. Turbine type 11-

Description: SIY!GLE-CASE ; Code:..............

F2. Fuel type(2)-

Description: COAL ; Code $\ldots \ldots \ldots \ldots \ldots \ldots \ldots \ldots$ 2

F3. Hew source performance status (Schedule NSPS):........

F4: Is this unit a candidate for retrofit?

$($ Enter $T$ for true, $F$ for false. $) . \ldots \ldots \ldots \ldots \ldots \ldots \ldots . \ldots \ldots$

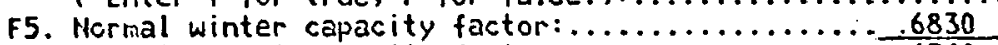

F6. Normal annua! capacity factor: ..............6710

F7. Fuel price in 1980 dollars. per Mistu: .........

F8. Unit code nane 1 imit 4 characters)

F9. Turbine/Boiler Retrofit Cost (Low) ( $\$ / \mathrm{kH}):$

F10. Turbine/Boiler Retrofit Cost (High) $(\mathrm{s} / \mathrm{kN}): \ldots$

F11. Electric Capacity Replacement Cost. (Low) (\$/kH:: 314.0

F12. Electric Capacity Replacement Cost $(\mathrm{High})(\$ / \mathrm{kH}):$

\section{Record $\mathbf{G}$}

G1. Unit capacity in megavatts:

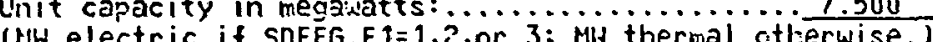

62. Unit heat rate (thousand Bturkth): $\ldots \ldots \ldots \ldots .12 .60$

\section{Turbine types are}

1 - single-case steam turbine,

2 - multi-case steam turbine,

3 - coribustion turbine, and

4 - heating boiler only.

\section{Fuel types are}

1 - nuclear,

2 - cosl.

3 - residual oil,

4 - distillate oil,

5 - natural gas, and

6 - natural gas, and

\section{PAGE FORMAT :3}

\section{DATA ECHO}

- Describing a single unit within the station described in the earlier FORMAT 12; from the Unit Definition Data sheet.

- For each FORMAT 12, the number of pages with FORMar 13 will equal the number of units within the station being described. 
Form SOFFG. $\therefore$.. $\because$ oistrict Heating \& Cooling

Form SDFFG

3. Percent sulfur in fuel $(\%)$

1.000

54. Percent ash in fuel $(\%)$ :

8.000

G5. Emissions control ( per cent; -

1. particulates $(\%): \ldots \ldots \ldots \ldots \ldots \ldots . . .99 .80$

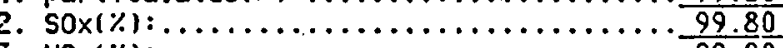

3. $110 \times(\%):$

99.80

56. Emissions (tons/Militu)

1. particulates:

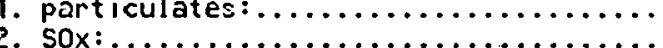

3. $110 x:$.

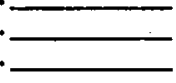

PAGE FORMAT 14

\section{DATA ECHO}

- Showing a continuation of FORMAT 13, with information needed to run the emissions portion of the model; from the Unit Definition Data Sheet.

- If the emissions portion is used, each FORMAT 13 will also have a FORMAT 14, the total number of FORMAT 14 pages being equal to the total number of units in the community. 
COST SCERARIO: TOH

THE DISTRICT STEAM SYSTEM SCEHARIO'S ENEREY FRACTIO IS

THE DISTRICT STEAM SYSTEH SCENARIO'S CAPACITY FRACTIOH IS

0.754

THE FOLIOHIHG BUIL.DING TYPES ARE INCLUOED IN THIS RJN:

RESIDENTIAL LOIS DENSITYHEATIH' \& HOT \$ATER

RESIDENTIAL HIGH DENSITYHEATINIG \& HOT HATER

COMMERCIAL/INSTITUTIOHALHEATING \& HOT HATER

INDUSTRIAL

LARGE BUILOIHG COOLIHG

INDUSTRIAL PROCESS

THIS RUN USED OHLY THE FOLLOHING 12 GRIDSQUARES IN P:QUA :

$\begin{array}{llllllllllll}12 & 14 & 21 & 22 & 23 & 24 & 30 & 31 & 32 & 33 & 40 & 41\end{array}$

FIXED CHARGE RATE: OUTPUT FINANCEAL ASSSUNPTIONS

$\begin{array}{rlll}\text { FIXED CHARGE RATE: } & 8.9 \% & & \\ \text { DISCOUNT RATE (REAL): } & 1.0 \% & \text { START OF CONSTRULTION: } & 1980 \\ \text { INFLATION RATE: } & 7.0 \% & \text { IN-SERVIZE DATE: } & 1983 \\ \text { REAL ESCALATION RATES } & & \text { RATE OF FETURN: } & 8.0 \% \\ \text { CAPITAL: } & 2.0 \% & \text { A.F.C. RITE: } & 8.0 \% \\ \text { OSH: } & 0.5 \% & \text { CAPITAL RECOVERY PERIOD: } 30 \text { YEARS } \\ \text { FUELS: } & \text { LIFETIME OF SYSTEI: } & 30 \text { YEARS }\end{array}$

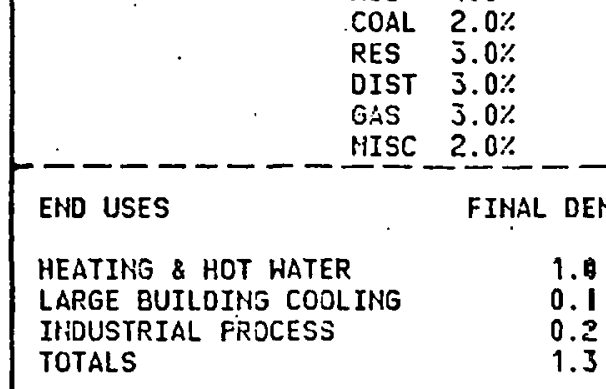

THERMAL DEMAND FOR 250 DEG.F. HOT HATER

1.4 TRILLIOH BTU

$\begin{array}{ll}\text { ELECTRICAL } & \text { FRAC-ION } \\ \text { GENERATION HEATRATE ELEC'RIC }\end{array}$ GIHH MMBTUAHHS ENER CR.

THERMAL

$\begin{array}{llllll}\text { ANHIUAL } & 271 . & 12.917 & 0.132 & 131 . & 5.250 \\ \text { HINTER } & 186 & 13.004 & 0.106 & \end{array}$

PAGE FORMAT 15

DATA ECHO (ajove line only)

- Describes financial and other operating assumptions; from the Scenario Definition Sheet, with input from community or ANL.

- Only one page of outpct will have this setup.

- Indicates grid squares used in the scenaric from Scenario Definition Sheet.

CALCULATION RESULTS (below line only)

- Describes bașic supply/demand data for the scenario and limited number of grid squares being considered.

- Thermal demand limited to the grid squares listed in the data echo above.

- Factors in conversion of efficiency losses, including those due to, absorption cooling at $67 \%$ efficiency. 


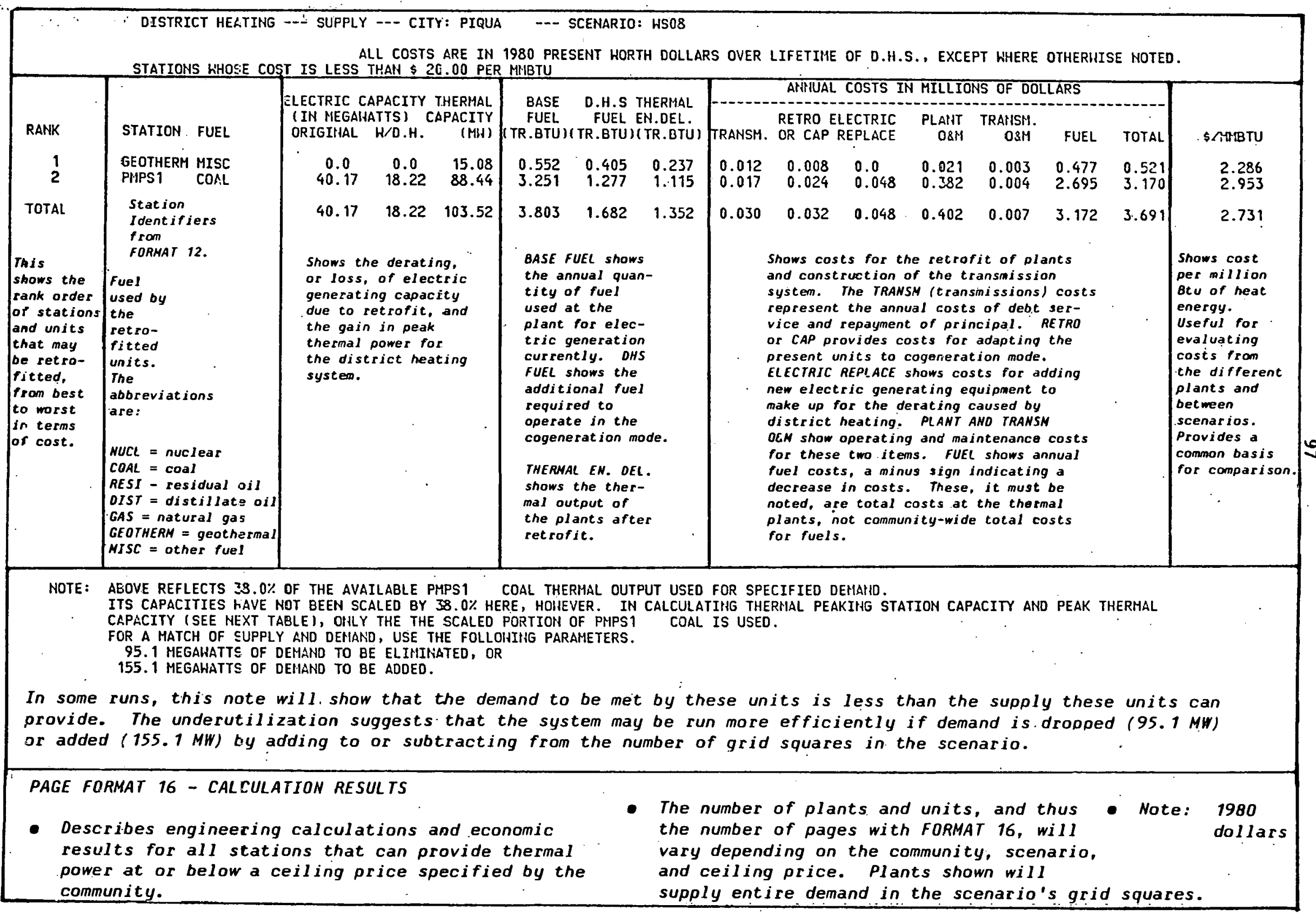


DISTRICT HEATIMG --- SUPPLY --- CITY: PIQUA

A TOTAL HIIITER ELECTRIC DERATIHIG

a NET HIHTER ELECTRIC CAPACITY LOSS

$C$ WINTER ELECTRIC CAPACITY CREDIT

8.35 MEGAHATTS

1.58 IIEGANHATTS

6.76 MEGAILATTS

21.95 MEGAHATTS

- CAPACITY PERMANENTLY DERATED

CAPACITY

E THERMAL PEAKING STATIOHS

MEEALATTS

F NEH PEAKING BOILER

79.44

AHNUAL CAPITAL

INVSTMIST

COSTS

79.44

0.09

38.14

ANNUAL THERHAL EHERSY DELIVERED

PEAK HINTER THERMAL DEMAND

H PEAK SUITIER THERMAL DEMATID

PEAK THERIAAL CAPACITY

THEFIMAL RESERVE ON PEAK

$$
\begin{aligned}
& 1.35 \text { TRILLIOH BTU } \\
& 115.33 \text { NEGAWATTS } \\
& 45.13 \text { MEGAHATTS } \\
& 128.14 \text { HEGAHATTS } \\
& -0.00 \%
\end{aligned}
$$

\section{LINE BY LINE DESCRIPTION}

A. Shows the seasonal loss in electric generating capacity, total -- which does not include consideration of the electric demand that will be reduced bu the district heating system.

B. Shows the seasonal loss in capacity, ne:-- which does take the demand reduction into consideration.

c. Shows the reduction in demand for electricitg due to district heating/coolung.

D. Shows capacity permanently lost, due to conversion of single-stage turbunes to cogeneration. Other turbines may be used to generate their full electric capacity if heat is not required.

E. Shows costs for new boiler capacity. needed to meet peak loads.

F. System-wide annual thermal energy delivered.

G. Seasonal peak demands, system wide.

H. Peak supply available, system wide.

I. Indicates whether the system, as designed, has thermal reserve built in.

\section{PAGE FORMAT 17}

CALCULATION RESULTS

- Describes changes in electric generating capacity due to dis. trict heating.

- Describes new boiler required, if any.

- Describes peak demands for scenario.

- Only one page of output will have this format. 


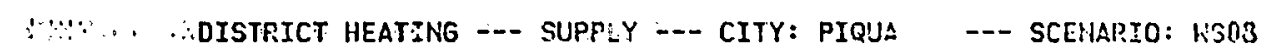

NLL COSTS ARE IN 1980 PRESEHT HORIH COLLARS OVER LIFETIME OF D.H.S., EXCEPT IHERE OTHERIVISE HOTEU.

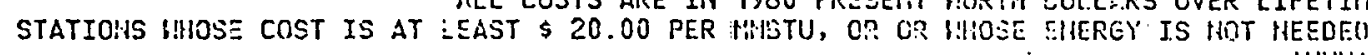
AHHIUAL COSTS IN HILLIOHS OF OOLLARS

ELECTRIC CAPACITY THEAMILL BASE D.H.S TIERHAL
(IH MEGAHATSS) CAFHCITY FUEL FUEL EIT.DEL.

RAHK STATIOH FULL OEIGINA. W/D.H. (HI) (TR.BTU)(TR.BTU)(TF.ETUI TREHEM. OR CAP REFLACE OSII OSII FUEL TOTAL EAAHIBTU

$\begin{array}{llllllllllllllll}3 \text { PHPS1 DIST } & 20.03 & 13.00 & 40.00 & 0.381 & 0.041 & 0.150 & 0.037 & 0.010 & 0.011 & 0.059 & 0.009 & 0.323 & 0.443 & 2.934\end{array}$

$\begin{array}{lllllllllllllll}\text { FIIPS1 CONL } & {[1]} & {[1.1]} & 3.0 & {[1]} & 0.04 & 0.02 & 0.02 & 0.00 & 0 & 0.01 & 0.01 & 0.03 & 0.11 & 5.55 \\ \text { GEOTHERII HISC } & {[1]} & {[1]} & 4.9 & {[1]} & 0.15 & 0.09 & 0.01 & 0.00 & 0 & 0.01 & 0.00 & 0.17 & 0.20 & 2.44\end{array}$

[1] THESE ARE FORTICHS OF EXISTIMG UIITS i D.S.S. ENERGY Al:U FIJEL 1 2.6.6\% AND CAPACITY ( $24.6 \%$ ) HHICH ARE MOT AVAILAELE FOR THE

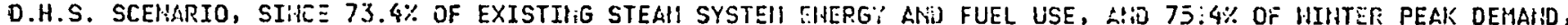

IS IHSIDE THE D.H.S. SCEHLRIO. ORIGINAL AND SETROTIT ELFCTRIC CAPACITY AID BASE FUEL USE ARE ALREAOY

ACCOUNTED FGR IH ACOL'

PAGE FORMAT 18

CAICULATION RESULTS

- Sketches engineering information about the remaining plants and units. The plants and units listed here either:

(1) have no theimal energy available because they are located far outside the scenario boundaries, or

(2) are expensive to operate and thus less feasible from a cost standpoint than the other plants.

- Only one page of output will have this format. 


\section{Emiss $\frac{\text { Form }}{\text { Ons input data }}$}

Name of Community: PIQUA

Record A

A1. Is NEDS point source output data available?

(Enter $T$ if true, $F$ i false.).$\ldots \ldots \ldots \ldots \ldots \ldots \ldots \ldots \ldots$

42. Fuel efficiencies $(1)$ by fuel type and end use -

1. Natural gas

Residential low density: $\ldots \ldots \ldots \ldots \ldots \ldots .5780$
Residential high density: ..........5780

Commercial/Institut i onal : ...........

Industrial space heat:..............

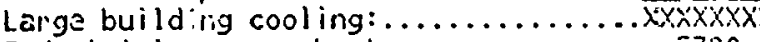

2. 0 il

Industrial process heat :........... 5780

Residential low density: ........... 5540

Residential high density:........... 5540

Commercial/zirstitutional : ........... 5540

Industrial space heat: $\ldots \ldots \ldots \ldots \ldots \ldots .5540$

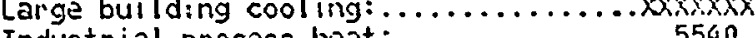

3. Coal

Ind $r$ ial process heat $: . . \ldots \ldots \ldots \ldots \ldots .5540$

Residential low density:............. 50 .

Residential hich density: ............

Residential high density:.............5.

Commercial/Institutional

Industrial space heat:

Large building cooling:

$\frac{5000}{x \times 1 \times 2 \times 1 \times x}$

Industrial

4. Electricity

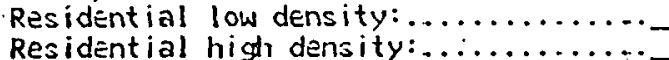

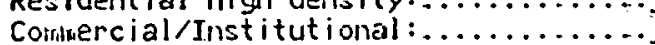

Cominercial/Institut i onal.

Iridustrial space heat:

5000

Large building cooling:

5. Existing district steain system.

Residential low density:

Residential high density:

Industrial space heat:

Large building cooling:

Industrial process heat $\ldots \ldots \ldots \ldots \ldots \ldots \ldots \ldots$

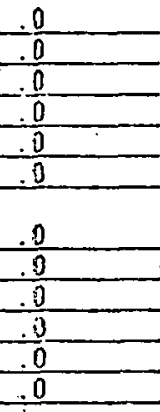

1 These are end-use efficiencies (decinal). To obtain the default values, simply leave blank.
PAGE FORMAT 19

\section{DATA ECHO}

- Showing emissions input from the community, for the Emissions Input oata Sheet.

- Only one page of output will have this format. 
PAGE FORMAT 20

\section{Form EDFB}

Name of Eommunity:

PIQUA

Record B

B1. Distillate fraction of oil use by end-use -

Residential low density: ............. 1.000

Residential high density: .......... 1.000

Commercial/Institutional.

Industrial space hear:

.6100

Industrial process heat :............6100

B2. Percent sulfur by weight in distillate oil -

Residential low density:............2000

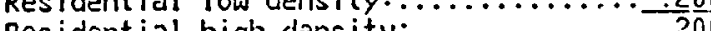

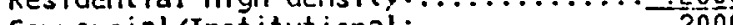

Comimercial/institutional:

Industrial process heat:.

B3. Percent sulfur by weight in residuai 0 i

Residential low density:

$0 ; i$

(n)............ 8000

Comercial/Institutional : $\ldots \ldots \ldots \ldots \ldots+\frac{80}{8000}$

Industrial space heat: .............. 8000

Industrial process heat: .

B4. Percent sulfur by weight in coal by sector -

Residential low density:............7000

Residential low density: $\ldots \ldots \ldots \ldots \ldots . .7000$

Residential high density: .......... .7000

Comercial/Inst i tut ional : . .........7000

Industrial space heat:

Industrial process heat: .............7nno

B5. Percent ash by weight in coal by sector

Residential low density:.......... 1.300

Residential high density: .............

Commercial/Institutional :............. 1.300

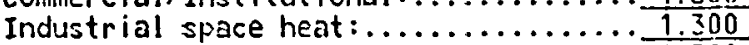

Industrial process heat: $\ldots \ldots \ldots \ldots \ldots \ldots \ldots$

66. Heat content of coal(1) (Mistu/ton): .........24.00

B7. Heat content of resicual oil(2) (lisisturkall: .... 148.0

88. Heat content of distillate oill3) (Militu/kgall:.. 137.0

B9. Heat content of nat gas (4) (Muluturillion cu, ft): 1030.

B9. Heat content of nit

1 Typical value for coal: 24 MMBtu/ton.

2 Typical value for residual oil: 148 MMBtu/thousand gallons.

3 Typical value for distillate oil: 137 MNBtu/thousand gallons.

4 Typical value for natural gas: $1000 \mathrm{MMBtu} / \mathrm{million}$ cubic feet.

\section{DATA ECHO}

- Showing a continuation of FORMAT 19; from the Emissions Input Data Sheet.

- Only one page of output will have this format. 
DISTRICT HEATING --- EMISSIONS --- CITY: JIQUA --- SCENARIJ: HS08

BEFORE DISTRICT HEATIHG AFTER DISTRICT HEATING

AlHIUAL

EMISSIONS IN TOHS/YEAR

TR.BTU PART. SOX HOK TR.ETU PART. SOX NOX

NEHBLBLR

COAL

0.0

0.0

0.0

0.0

0.0

0.0

0.0

0.0

PHPS1

COAL

DISTIL.

3.25
0.38

17.3

$\begin{array}{rrr}5.1 & 2.4 & 4.02 \\ 4.9 & 94.4 & 0.33\end{array}$

21.4
6.0

$6.4 \quad 3.0$

GEOTHERM

MISC.

0.55

0.0

0.0

0.0

0.55

0.0

0.0

0.0
PAGE GORMAT 21

CALCULATION RESULTS

- Shows emissions, fuel use, and fuel types for each station and unit considered for retrofit.

- The number of pages of this type wi:l depend on the number of units considered.

- Emissions in tons per year; PART sijnifies particulate matter, $\mathrm{SO}_{x}$ signifies sulfur oxides, and NO ${ }_{x}$ signifies nitrogen oxides. 


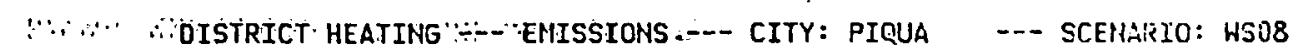

- BEFORE DISTRICT HEATIHG

ALIIIUAL

FUELUSE - EMISSIONS IN TONS/YEAR TR.BTU
AFTER DISTRICT HEATIH

AIIIUUAL

FUELUSE EIISSTOHS IN TCISSYYEAR

TR.BTU FAKT. SOX HOX

TOTAL FOR ALL STATIONS:

ELECTRIC SYSTEM

$\begin{array}{llrlrlrrr}\text { NUCLEAR } & 0.0 & 0.0 & 0.0 & 0.0 & 0.0 & 0.0 & 0.0 & 0.0 \\ \text { COAL } & 3.11 & 16.6 & 4.9 & 2.3 & 3.94 & 21.0 & 6.2 & 3.0 \\ \text { RESIDUAL } & 0.0 & 0.0 & 0.0 & 0.0 & 0.0 & 0.0 & 0.0 & 0.0 \\ \text { DISTIL. } & 0.33 & 7.0 & 4.9 & 94.4 & 0.33 & 6.0 & 4.2 & 82.0 \\ \text { GAS } & 0.0 & 0.0 & 0.0 & 0.0 & 0.0 & 0.0 & 0.0 & 0.0 \\ \text { MISC. } & 0.0 & 0.0 & 0.0 & 0.0 & 0.0 & 0.0 & 0.0 & 0.0\end{array}$

TOTAL FOR ALL STATIONS:

STEAH SYSTEM

$\begin{array}{lllllllll}\text { NUCLEAR } & 0.0 & 0.0 & 0.0 & 0.0 & 0.0 & 0.0 & 0.0 & 0.0 \\ \text { COAL } & 0.14 & 0.7 & 0.2 & 0.1 & 0.08 & 0.4 & 0.1 & 0.1 \\ \text { RESIDUAL } & 0.0 & 0.0 & 0.0 & 0.0 & 0.0 & 0.0 & 0.0 & 0.0 \\ \text { DISTIL. } & 0.0 & 0.0 & 0.0 & 0.0 & 0.0 & 0.0 & 0.0 & 0.0 \\ \text { GAS } & 0.0 & 0.0 & 0.0 & 0.0 & 0.0 & 0.0 & 0.0 & 0.0 \\ \text { MISC. } & 0.55 & 0.0 & 0.0 & 0.0 & 0.55 & 0.0 & 0.0 & 0.0\end{array}$

TOTAL FOR ALL STATIONS:

$\begin{array}{llrrrrrrr}\text { NUCLEAR } & 0.0 & 0.0 & 0.0 & 0.0 & 0.0 & 0.0 & 0.0 & 0.0 \\ \text { COAL } & 3.25 & 17.3 & 5.1 & 2.4 & 4.02 & 21.4 & 6.4 & 3.0 \\ \text { RESIDUAL } & 0.0 & 0.0 & 0.0 & 0.0 & 0.0 & 0.0 & 0.0 & 0.0 \\ \text { DISTIL. } & 0.35 & 7.0 & 4.9 & 94.4 & 0.33 & 6.0 & 4.2 & 82.0 \\ \text { GAS } & 0.0 & 0.0 & 0.0 & 0.0 & 0.0 & 0.0 & 0.0 & 0.0 \\ \text { MISC. } & 0.55 & 0.0 & 0.0 & 0.0 & 0.55 & 0.0 & 0.0 & 0.0 \\ \text { TOTALS } & 4.18 & 24.3 & 10.0 & 96.8 & 4.90 & 27.5 & 10.6 & 85.0\end{array}$

\section{PAGE FORMAT 22}

\section{CALCULATION RESULTS}

- Shows results from the emission package, broken down by fuel type and electric generating olants and new steam-only plants.

- Only one page of this setup will appear.

- This is a condensation and summary of data from FORMAT 21. 
DISTRICT HEATIHG --- EMISSIONS --- CITY: PIQUA

AHNUAL
FUELUSE
TR.BTU

--- SCENARIO: HSOB

ALNUUAL EMISSIOHS

PART.

(TONS)

sox

(TOtis)

(TONS)

GRIDSQUARE \# 21:

33

RESIDENTIAL LOH DEHSITY HEATIHG \& HOT WATER RESIDEHTIAL HIGH DENSITY HEATING \& HOT HATER COMHERCIAL/IHSTITUTIOHAL HEATING \& HOT WATER IHIDUSTRIAL HEATING \& HOT HATEER

$\begin{array}{lllll}0.07 & \text { LREA } & 0.36 & 0.50 & 2.69 \\ 0.01 & \text { LREA } & 0.04 & 0.05 & 0.28 \\ 0.01 & \text { LREA } & 0.11 & 0.09 & 0.89 \\ 0.01 & \text { LREA } & 0.07 & 0.50 & 0.73 \\ 0.02 & \text { LREA } & 0.19 & 1.48 & 1.93 \\ 0.12 \text { LREA } & 0.75 & 2.62 & 6.51\end{array}$

TOTALS

GRIDSQUARE \# 22:

43

RESIDEHTIAL LOH DENSITY HEATING \& HOT HATER

$\begin{array}{lllll}0.14 & \text { LREA } & 0.78 & 1.08 & 5.84 \\ 0.00 & \text { LREA } & 0.00 & 0.00 & 0.02 \\ 0.01 & \text { LREA } & 0.08 & 0.07 & 0.67 \\ 0.00 & \text { LREA } & 0.02 & 0.17 & 0.24 \\ 0.01 & \text { LREA } & 0.06 & 0.50 & 0.65 \\ 0.16 & \text { LREA } & 0.94 & 1.82 & 7.42\end{array}$

PAGE :ITMAT 23

\section{CALICU:ATION RESUL TS}

- Shors fuel use and emissions at each grid square in the community.

- The number of pages with this se:ur is equal to half the communit.f's grid squares ldata for two squạres appear on each pagel.

- Infat data used in the Piqua examole did not include the NEDS data file. The model therefore calculated area emissions using the input fuel-use data. With the NEJS file, point sources may also be included, and emissions would than be reported:

ARE.A (as above)

$P T$ SH (point emissions from space heating)

PT DTH (other point emissions) 
ODISTRICT HEATING:--- EHISSIONS--- CITY: PIQUA -..- SCEHARIO: HSOS FIXED CHARGE RATE: $8.9 \%$

SUPPLY SCENARIO: WSU8

CUST SCENARIO: LOH

D.H.S. FRACTION ELECTRIC REFLACENENT CAPACIT/ COSTS 0.50

THIS RLN USED THE FOL:OHIIIG BUTLOING TYPES:

RESIDENTIAL LOW DENSITY HEATING \& HOT WATER

RESIDENTIAL HIGH DENSITY HEATIHG \& HOT WATER

COHMERCTAL/INSTITUTIONAL HEATING \& HOT HATER

IHIDUSTRIAL

LARGE BUILDING COOLINJ

INDUSTRIAL PROCESS

THIS RUI USED THE FOLLOWING 12 OF THE 54 ERIDSQUARES III. PIRUA $\begin{array}{llllllllllll}12 & 14 & 21 & 22 & 23 & 24 & 30 & 31 & 32 & 33 & 40 & 41\end{array}$

ENTIRE CITY HEATING DEMAND AHID LOCAL FUEL US

ADJUSTED EFFICIENCIES

EUILDING TYPE

RESIO SNTIAL LO'A DENSITY HEATING \& HOT HATER

RESID ENTIAL HIGH DENSITY HEATING \& HOT WATER

COHIMERCIAL/INSTITUTIONAL HEATING \& HOT WATER

INDUSTRIAL

HEATING \& HOT WATER

INDUSTRIAL PROCESS

$\begin{array}{lll}\text { GAS } & \text { OIL } & \text { COAL } \\ 0.58 & 0.55 & 0.50 \\ 0.58 & 0.55 & 0.50 \\ 0.58 & 0.55 & 0.50 \\ 0.58 & 0.55 & 0.50\end{array}$

PAGE FORMAT 24

\section{DATA ECHO}

- Restating basic scenario assumptions from the Scenario Definition Sheet.

- Only one page with this format will appear.

- States fuel efficiencies from the Emissions Input Data Sheet.

\section{CAL:CULATION RESULTS}

Provides community-wide emissions before and after district heating to illustrate potential air-quality benefits for the grid squares in the scenario.

BEFORE OISTRICT HEATING AIViUALL
FUELUSE
TR.BTU

RESIDENTIAL LOH DENSITY HEATIHG \& HOT HATER

AFTER DISTRICT HEATING

RESIDENTIAL HIGH DENSITY HEATING \& HOT HATER COHHERCIAL/INSTITUTIOHAL HEATING \& HOT WATER IHDOUSTRIAL REATING \& HOT WATER INDUSTRIAL PROCESS TOTALS

\begin{tabular}{|c|c|c|c|c|c|c|c|c|c|}
\hline $\begin{array}{l}\text { WUAL } \\
\text { ELUSE } \\
\text { BTU }\end{array}$ & & $\begin{array}{l}\text { ANHUUAL } \\
\text { PART. } \\
\text { ITORIS) }\end{array}$ & $\begin{array}{c}\text { EMISSIO } \\
\text { SOX } \\
\text { (TOH'S) }\end{array}$ & $\begin{array}{l}\text { NS } \\
\text { (TOHS } \\
\text { (TOHS) }\end{array}$ & $\begin{array}{l}\text { ANNIUAL } \\
\text { FUELUSE } \\
\text { TR.BTU }\end{array}$ & & $\begin{array}{l}\text { AYfiNUAL } \\
\text { PART. } \\
\text { (TOUIS) }\end{array}$ & $\begin{array}{c}\text { EMISSIO } \\
\text { SOX } \\
\text { (TOHS) }\end{array}$ & $\begin{array}{l}\text { HOX } \\
\text { (TOHS) }\end{array}$ \\
\hline 1.4 & AREA & 7.5 & 10.4 & 56.6 & 0.2 & AREA & 1.2 & 1.6 & 8.7 \\
\hline 0.0 & AREA & 0.2 & 0.3 & 1.6 & 0.0 & AREA & 0.0 & $0.0^{\prime \prime}$ & 0.1 \\
\hline 0.4 & AREA & 2.8 & 2.4 & 23.7 & 0.1 & AREA & 0.8 & 0.7 & 6.7 \\
\hline 0.2 & AREA & 1.3 & 9.9 & 14.5 & 0.0 & AREA & 0.4 & .3 .2 & 4.7 \\
\hline 0.5 & AREA & 4.5 & 35.8 & 46.6 & 0.2 & AREA & 1.5 & 11.7 & 15.2 \\
\hline .5 & AREA & 16.4 & 58.9 & 143.0 & 0.5 & AREA & 3.9 & 17.2 & 35.4 \\
\hline
\end{tabular}

\section{ATING} EMISSIONS ANIUAL FUELUSE

TR.BTU 


\section{Form $\frac{\operatorname{CDFA}}{\cos t}$}

Name of Community:

PIQUA

Pecord A

A1. On-site fuel prices(1) in 1980 dollars/MMBtu -

1. Natural gas (\$/Mistu) -

Residential low density:............ 3.900

Residential high density:............

Comiercial/Institutional $\ldots \ldots \ldots \ldots \ldots \ldots . . .150$

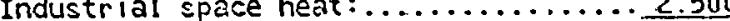

Large building cooling:...............

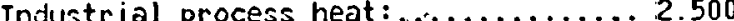

2. 0 il ( $\$ /$ Riibtu)

Residential low density: ..........6.600

Residential high density: ..........6.6.600

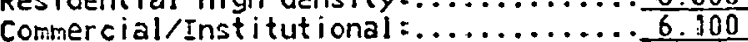

Industrial space hat: ..................

Large building cooling: ...........

Industrial process heat:............ 5.200

3. Coal (5/Minitu) -

Residential low density:............ 1.500

Residential high density: ............. 1.500

Comercial/Institutional: .............. 1.500

Commercial/Institutional .............

Large building cooling:.....................XXXXX

Industrial process heat: ............ 1.500

4. Electricity $(\$ / M i B t u)$ -

Residential low density:.......... 15.50

Residential high density:.........15.50

Coritercial/Institutional

Industrial space heat:

Larse building cooling:

Industrial process heat:

5. Existing district steam syster (simmBtu) -

Residential low density: .......... 5.000

Residential high density:.........

Commercial/Institutional $\ldots \ldots \ldots \ldots \ldots \ldots \frac{5.000}{5.000}$

Industrial space heat $\ldots \ldots \ldots \ldots \ldots \ldots \ldots, 5.00$

Large building cooling:.................

Industrial process heat: .......... 5.n00

1 Recotmended conversion factors:

Natural gas 1,035 Btu/ cubic ft.

Distillate oil $\quad 133,690$ Btu/gallon.

Residual oil $\quad 149,590 \mathrm{Btu} / \mathrm{gallon}$.

anthracite coal 25.2 pilBtu/ton.

Electricity $\quad 3,4: 2$ Btu/kuh.

Steam 1000 Btu/pound.

\section{OATA ECHO}

- Restating fuel prices; input from community (Fuel Cost Data Sheet).

- Only one page of this format will appear. 
THIS RUH USED. THE FOLLOHING BUILDIMG TYPES:

RESICENTIAL LON DENASITY HEATING \& HOT HATER

RESIUENTIAL HIEH DENSSIY.HEATIIG \& HOT HATER

COPHIERCIAL/IHSTITUTIOHAL HEATING \& HOT UATER

IHDUSTRIAL

LARGE BUILDIYIS COOLINIS

IYICUSTRIAL PROCESS

THIS RUN USED THE FOL:CHING 12 OF THE 54 GRIDSQUARES IN PIQUA

$\begin{array}{lllllllllllll}12 & 14 & 21 & 22 & 23 & 24 & 30 & 31 & 32 & 33 & 40 & 41\end{array}$

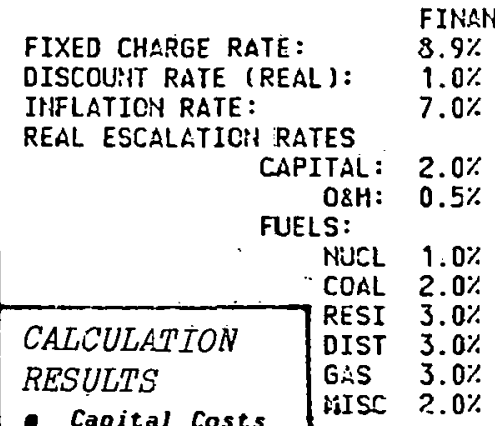

- Showing financial assumptions input from community and ANL (Scenario Definition Sheet).

- Unly one page of this format will appear, see below.

- The data echo is identical to fORMAT 15.

- Capital costs hiss $2.0 \%$

OISTRICT HEATING SYSTEM CAPITAL COSTS (GILESS OTHERHISE NOTED, IN MILLION 1 S8O DOLLARS)

FIXED COSTS

START OF COHSTRUCTION:

IN-SERVICE DATE

1980

1983
$8.0 \%$

A.F.C. RATE:

$3.0 \%$

CAPITAL RECOVERY PERIOD: 30 YEARS

LIFETIME OF SYSTEM: $\quad 30$ YEARS

1 TOTAL INNESTMENT (AT START-UP)

2 TOTAL LIFETIHE CDSTS

3 AVERAGE Ali:UUAL CDSTS

4COSTS.IPIBTU

1. Initial capical required per component.

2. Capital required over $30-$ yr life, equal to ited s include Item $\mathrm{T}$.

3. Average annual capita: costs.

4. Costs per aillion otu; useful in

TRANSMISSIGN

VARIASLE COSTS

TRANSMISSIGY LOOP

OEM and fuel costs

AVERAGE AYHULAL COSTS

COSTSMTIBTU

\subsection{3}

0.836

0.023

\section{Transmission-}

syster capital

costs, i.e.

piping fiom

stations to

loop or dis-

tribution.

TOTAL COST OF FINAL DEMAND \$

4.447 PER MNBTU

BUTION

14.932

12.802

0.328

Thermal -

loop

piping

costs.

.

.

TRAIS

RAISMISSIOH
CSM

CSM
0.007
0.006

31.535
26.865

26.855
0.895

$0.6 \hat{3}$

tion Capital cost Costs of

or loop to

ividual

buildings.

PLANT
RETROFIT
1.120
0.950
0.032
0.025
Capital cost
of converting
necessary
lants to
cogeneration

12.317

buildings

BUILDING

REFLACEHENT
CAPÁCITY

10.550
0.352

0.270

1.666

1.428

0.048

retrofitting to teplace lost

electric gener-

ation equipment

for district capacity.

heat ing and

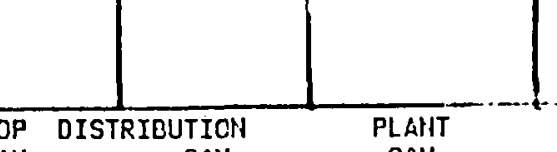

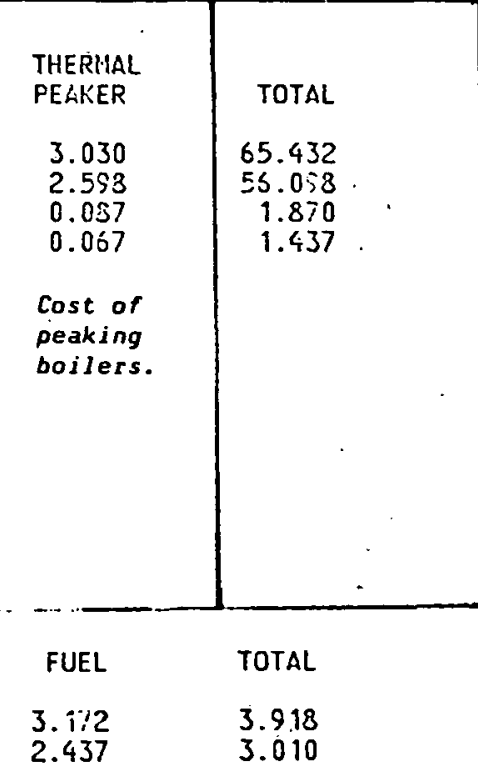

Cost per million btu of heat using this scenario; useful as a common basis for comparing among different scenarios. 
DISTRICT HEATIIIG -- COSTING --- CITY: PIGUA --- SCERISRIO: HSOE

THERMAL DEMAHD, FUEL USE AHID COSTS HITH EXJSTING SYSTEM

SPACE HEATING HOT HATER CITYHIDE BEFORE - D.H

AREL NOT IN D.HS

\begin{tabular}{|c|c|c|c|c|c|c|c|c|}
\hline & ARINUAL & ENHIUAL. & & ANBIIJAL & ANIUUAL & & GHITIUAL & AtHiUA \\
\hline 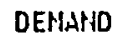 & FIISAL & FUEL & DEHAND & FIHIAL & FUEL & DEMAND & FINAL & \\
\hline 20 & DEHAiDD & DEMAIND & costs & DE.IAHD & QEFAAID & costs & DERTKMD & DEHAK' \\
\hline AMIE & TR.BTU & TR.BTU & \$ / FIMTU & TR.BTU & TR.BTU & \$All IGTU & TR.BTU & $T R$ \\
\hline
\end{tabular}

RESIDENTIAL LOH DENSITY

8.908

GAS
OIL
COAL.
ELECTRIC
OTHER

OTHER

TOTAL, ALL FUELS

TOTAL, ON-SITE FUELS

RESIDENTIAL HIGH DENSITY

GAS
OIL
COAL.
ELECTRIC
OTHER

TOTAL, ALL FUELS

TOTAL, ON-SITE FUELS

COMMERCIAL/INSTITUTIONAL

GAS
OIL
COAL
ELECTRIC
OTHER
AIL FUEIS

TOTAL, ALL FUELS

TOTAL, ON-SITE FUELS

IRDUSTRIAL

GAS
OIL
COAL
ELECTRIC
OTHER
OTS

TOTAL, AL: FUELS

TOTAL, OH-SITE FUELS
8.908

$\begin{array}{ll}0.766 & 1.325 \\ 0.036 & 0.065 \\ 0.003 & 0.005 \\ 0.049 & 0.162 \\ 0.013 & 0.020 \\ 0.866 & 1.577 \\ 0.804 & 1.395\end{array}$

8.898

$\begin{array}{ll}0.021 & 0.037 \\ 0.001 & 0.002 \\ 0.000 & 0.000 \\ 0.001 & 0.005 \\ 0.001 & 0.001 \\ 0.024 & 0.044 \\ 0.022 & 0.039\end{array}$

7.966

$\begin{array}{ll}0.223 & 0.386 \\ 0.003 & 0.006 \\ 0.001 & 0.002 \\ 0.009 & 0.029 \\ 0.008 & 0.012 \\ 0.244 & 0.435 \\ 0.227 & 0.393\end{array}$

9.243

$0.053 \quad 0.108$

$0.024 \quad 0.042$

$0.0 \quad 0.0$

$0.018 \quad 0.059$

$0.008 \quad 0.013$

0.1120 .223

$0.086 \quad 0.151$

9.243
8.908

$\begin{array}{ll}0.649 & 1.122 \\ 0.030 & 0.055 \\ 0.002 & 0.005 \\ 0.041 & 0.137 \\ 0.011 & 0.017 \\ 0.733 & 1.336 \\ 0.681 & 1.182\end{array}$

8.898

$\begin{array}{ll}0.002 & 0.00 \\ 0.000 & 0.00 \\ 0.000 & 0.00 \\ 0.000 & 0.00 \\ 0.000 & 0.00 \\ 0.002 & 0.00 \\ 0.002 & 0.003\end{array}$

$0.020 \quad 0.034$

0.001

$0.000 \quad 0.000$

$0.001 \quad 0.004$

$0.001 \cdot 0.001$

$0.023 \quad 0.041$

.7 .966

$\begin{array}{ll}0.063 . & 0.109 \\ 0.001 & 0.002\end{array}$

$\begin{array}{ll}0.000 & 0.001 \\ 0.002 & 0.008\end{array}$

$0.002: 0.003$

0.00690 .123

$\begin{array}{ll}0.064 & 0.111\end{array}$

$\begin{array}{ll}0.020 & 0.035 \\ 0.003 & 0.014 \\ 0.0 & 0.0 \\ 0.006 & 0.019 \\ 0.003 & 0.004 \\ 0.036 & 0.072 \\ 0.028 & 0.049\end{array}$

7.966

$\begin{array}{lll}0.160 & 0.277\end{array}$

$0.002 \quad 0.004$

$0.001^{\circ} 0.001$

$0.006 \quad 0.009$

$0.175 \quad 0.312$

$0.163 \quad 0.232$

9.243

$\begin{array}{lll}0.042 & 0.073\end{array}$

$0.016 \quad 0.029$

$0.0 \quad 0.0$

$0.012 \quad 0.040$

$0.076 \quad 0.159$

$0.058 \cdot 0.102$ $\begin{array}{ll}0.001 & 0.002 \\ 0.000 & 0.001\end{array}$

$0.006 \quad 0.009$
PAGE FORMAT -27

\section{CALCULATION RESULTS}

- Shows thermal demands, fuel use, and costs for the existing heating and cooling supply situation.

- To be used to compare current situation to district heating supply system.

- Calculations are for areas inside and outside the district system.

$0.006 \quad 0.021$

- Only one page of this format will appear. 
$\therefore$.DISTRICT HEATING - - COSTING - - CITY: PIQUA --. SCENARIO: WSO8

$\because:$ THERMAL DEMAND $\because$ FUEL:USE :AND COSTS HITH EXISTING SYSTEM.

COOLIHIS AHD ITID. FROCESS $\%$ CITYHIDE BEFORE D.H. AREA HOT IN D.H.S.

DEHATiD FTNAL FUEL DEMAND FINAL FUEL DEMAHD ANHUAL AMHUUAL

LARGE BUILDING COOLING

GAS

OIL

ELECTRIC OTHER

TOTAL, ALL FUELS

TOTAL: ON-SITE FUELS

INDUSTRIAL PROCESS

GAS
OIL
COAL
ELECTRIC

ELECTRIC

TOTAL, ALL FUELS

TOTAL: ON-SITE FUELS

TJTAL, ALL BUILDINGS

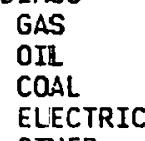

TOTAL ALL FUELS

8.333

$\begin{array}{ll}0.0 & 0.0 \\ 0.0 & 0.0 \\ 0.0 & 0.0 \\ 0.168 & 0.271 \\ 0.0 & 0.0 \\ 0.168 & 0.271 \\ 0.0 & 0.0\end{array}$

8.087

$\begin{array}{ll}0.185 & 0.320 \\ 0.085 & 0.154\end{array}$

0.0

0.0

$0.016 \quad 0.025$

$0.286 \quad 0.025$

$\begin{array}{ll}0.286 & 0.459 \\ 0.270 & 0.474\end{array}$

8.600

$\begin{array}{ll}1.253 & 2.176 \\ 0.149 & 0.269 \\ 0.004 & 0.008 \\ 0.245 & 0.526 \\ 0.045 & 0.070 \\ 1.700 & 3.049 \\ 1.410 & 2.452\end{array}$

8.333

$\begin{array}{ll}0.0 & 0.0 \\ 0.0 & 0.0 \\ 0.0 & 0.0 \\ 0.066 & 0.107 \\ 0.0 & 0.0 \\ 0.066 & 0.107 \\ 0.0 & 0.0\end{array}$

8.087

$0.060 \quad 0.105$

0.0280 .050

$0.0 \quad 0.0$

$0.005 \quad 0.008$

$0.095 \quad 0.163$

$0.088 \quad 0.155$

8.488

$\begin{array}{ll}0.262 & 0.454 \\ 0.042 & 0.076 \\ 0.001 & 0.001 \\ 0.032 & 0.159 \\ 0.012 & 0.019 \\ 0.399 & 0.709 \\ 0.305 & 0.531\end{array}$

PAGE FORMAT 28

\section{CALCULATION RESULTS}

- Shows a continuation of FORMAT 27, with totals.

- Only one page with this format will appear. 


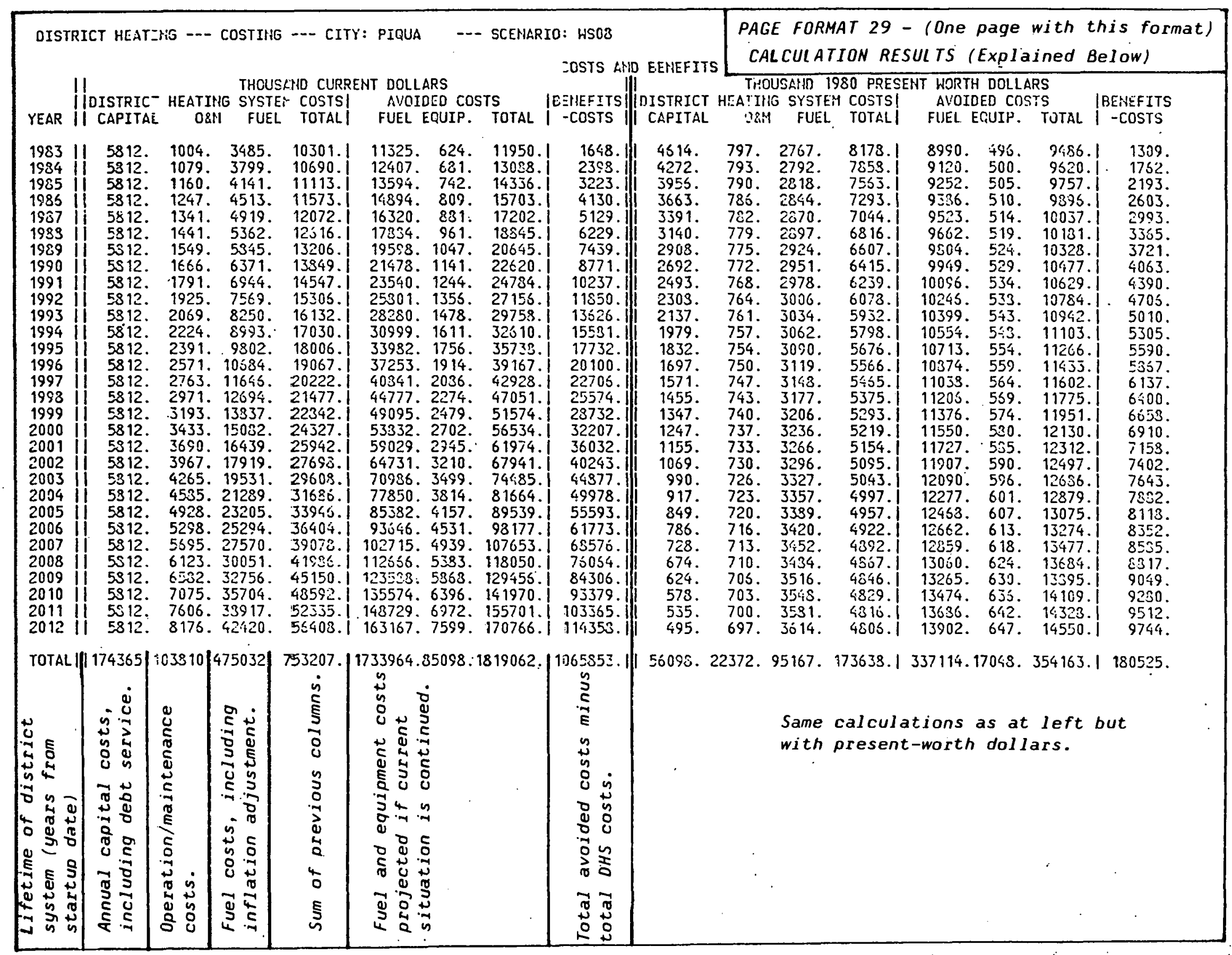


a. $\because \because \because$ DISTRICT HEATING -- COSTING - - CITY: PIQJA -- SCENARIO: HS08

* * firlanctal sumiary ***

CUMU:ATIVE NET BENEFITS 175. MILLION 1980 PRESENT HORTH DOLLARS

SAVIH'GS-TO-INVESTMENT RATIO (N.P.H.) 4.16

DISCOUNTED PAYBACK PERIOD 8.9 YEARS

YEAR OF CASH FLOH TURNAROUND

CURRENT DOLLARS

1983

PRESENT HORTH DOLLARS: 1983

* * * fuel use surmary * * *

FUEL USE AND SAVIHIGS, TRILLION BTU

BEFORE DISTRICT HEATING
FUEL UTILITY BUILDIHIG TOTAL

AFTER DISTRICT HEATING

NUCLEAR

COAL

RESILUAL

DISTIL.

GAS

TOTALS

$\begin{array}{lll}0.0 & 0.0 & 0.0 \\ 3.251 & 0.008 & 3.259 \\ 0.0 & 0.078 & 0.078 \\ 0.381 & 0.191 & 0.572 \\ 0.0 & 2.176 & 2.176 \\ 0.552 & 0.0 & 0.552 \\ 4.185 & 2.452 & 6.637\end{array}$
UTILITY BUILDIHG

$\begin{array}{ll}0.0 & 0.0 \\ 4.018 & 0.001 \\ 0.0 & 0.025 \\ 0.331 & 0.050 \\ 0.0 & 0.454 \\ 0.552 & 0.0 \\ 4.901 & 0.531\end{array}$

PAGE FORMAT 30

CALCULATION RESULTS.

- Financial Summary (above) and fuel Use Summary (below).

- Total benefits and other vital information; definitions in Appendix $A$.

- Fuel use over system lifetime for this scenario.

- Only one page with this format will appear.

MET SAVIHIGS TOTAL UTILITY BUILDIHG TOTAL

$\begin{array}{llll}0.0 & 0.0 & 0.0 & 0.0\end{array}$

$\begin{array}{cccc}4.019 & -0.766 & 0.006 & -0.760 \\ 0.025 & 0.0 & 0.053 & 0.053\end{array}$

$\begin{array}{llll}0.382 & 0.0 & 0.053 & 0.053 \\ 0.352 & 0.050 & 0.140 & 0.191\end{array}$

$\begin{array}{llll}0.454 & 0.0 & 1.722 & 1.722\end{array}$

$\begin{array}{llll}0.552 & 0.0 & 0.0 & 0.0\end{array}$

$\begin{array}{llll}5.432 & -0.716 & 1.922 & 1.205\end{array}$ 
PAGE FORMAT 31

\section{CAICUIAATION RESULTS}

- Thermal Load Map. This map is a graphic display of the data found in FORMAT 7 and will be color-coded when delivered.

- PMPS.1 and boiler plants located in same area (symbols therefore superimposed on each other).

\section{PEAK THERMAL DEMAND FOR PIQUA.}

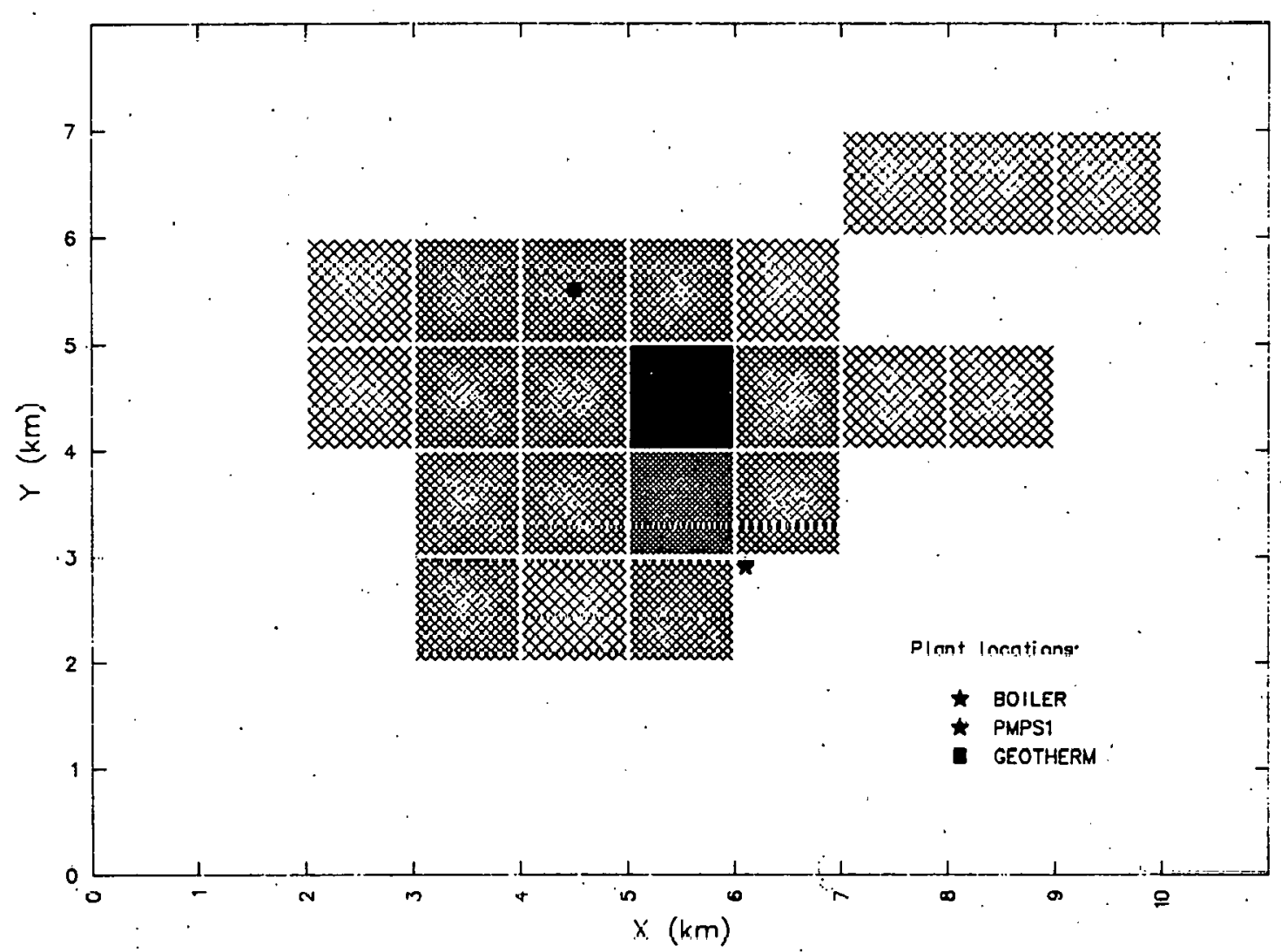

LEGEND FOR PEAK THERMAL DEMAND MAP OF PIQUA

Building sectors included:

RESIDENTIAL LOW DENSITY HEATING \& HOT WATER RESIDENTIAL HIGH DENSITY HEATING \& HOT WATER COMMERCIAL/INSTITUTIONAL HEATING \& HOT WATER INDUSTRIAL LARGE BUILDING COOLING

INDUSTRIAL PROCESS

Poak lhormol demand ronges:

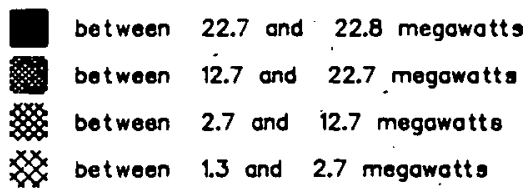


Table H.1 Classification of Output Data by Community Area to Which They Apply and by Page Format (s) on Which They Are Presented

\begin{tabular}{|c|c|c|c|}
\hline $\begin{array}{l}\text { Type of } \\
\text { Output } \\
\text { Data }\end{array}$ & $\begin{array}{l}\text { Applicable } \\
\text { Area of } \\
\text { Community }\end{array}$ & $\begin{array}{c}\text { Page Format (s) } \\
\text { for } \\
\text { Data Echoes }\end{array}$ & $\begin{array}{l}\text { Page Format (s) } \\
\text { for Calculation } \\
\text { Results }\end{array}$ \\
\hline Demand & Entire community & 1,2 & 6 \\
\hline Demand & Al1 grid squares & 3,4 & $5,7,31$ \\
\hline Demand & Scenario area on $1 y$ & & 27,28 \\
\hline Cost & $\begin{array}{l}\text { Entire community } \\
\text { and scenario area }\end{array}$ & 8,9 & \\
\hline Demand & Scenario area only & $10,15^{a}$ & $15^{a}$ \\
\hline Supply, Cost & Scenario area on $1 y$. & $11,12,13,14$ & $16,17,18$ \\
\hline Emissions & Entire community & 19,20 & \\
\hline Emissions & $\begin{array}{l}\text { Entire community } \\
\text { and scenario area }\end{array}$ & & 21,22 \\
\hline Emissions & Scenario area on $1 y$ & $24^{a}$ & $23,24^{a}$ \\
\hline $\operatorname{Cos} t$ & $\begin{array}{l}\text { Fuel prices, entire } \\
\text { community }\end{array}$ & 25 & \\
\hline Cost & $\begin{array}{l}\text { District system, } \\
\text { scenario area only }\end{array}$ & $26^{a}$ & $26^{a}, 27,28,29,30$ \\
\hline
\end{tabular}

aFormats on which both data echoes and calculation results are presented. The echn portinns of these formats have been determined by scenario input and are valid only for the scenario being run.

Demand data may be used locally for: (1) Verifying the preliminary estimates of other researchers; (2) finding areas of probable high thermal demands that can be the basis for making new scenarios using the areas with the highest thermal densities (and therefore best district-heating potential); and (3) comparing district heating and cooling with other energy-saving strategies. After the current demands are calculated, the effects of increased weatherization or use of other conservation techniques may be tested by changing the demand factor for scaling ${ }^{\dagger}$ space heating (format 1) and recording the effects on final demands ${ }^{\dagger}$ (format 6 ). Revised final demands can be compared to final demands of a district heating and cooling scenario (from the cost module, format 28). Because the costs of a district heating and cooling scenario would be known, independent calculations of the other conservation technique's costs would permit a better comparison of alternatives.

$\therefore$

$\therefore \therefore$ 
The demand map (formats 7 and 31) can be a useful tool in explaining thermal-density concepts to work group members or community residents. Its main function for the analyst is to aid in scenario construction by highlighting grid squares with the highest thermal density. $\dagger$

\section{H.3 SUPPLY OUTPUT}

The demand data, economic assumptions (format 9), scenario specifications (format 10), and utility-plant and boiler data (formats 11-14) provide the basis for the model to calculate the available thermal supplies and the costs that may be expected from use of those supplies.

The first page of the report (format 15) gives basic scenario information, starting with the name of the city and the scenario. The "District Steam System Scenario's Fraction" represents that portion of the load of the existing district steam system (DSS) included within the grid squares specified for the scenario. Also on format 15 is a list of building types and end uses, a list of the grid squares included in this scenario, and a list of the various financial assumptions. The last item on format 15 is a summary of the final annual demands for the scenario. The first numbers represent the end use requirements, and the final. figure represents the thermal demand for district-heating-system energy at the building after taking into account conversion efficiencies. The final numbers give the electrical and thermal loads -- as well as the electrical credits ${ }^{\dagger}$ stemming from replacement by the district system of electricity previously used but no longer needed.

Format 16 lists those stations that have been selected and ranked on the basis of cost (in dollars per $106 \mathrm{Btu}$ delivered) to provide energy for the district heating system. For electrical stations there is generally a moderate reduction in electrical capacity (from ORIGINAL to W/D.H.) and a lesser increase in fuel use (D.H.S. FUEL) to provide the district heating system's thermal energy (THERMAL EN. DEL.). These results are followed by. various components of the annual costs associated with the conversion and the average delivered energy cost -- with all costs represented in 1980 presentworth dollars, adjusted by the user-specified inflation and discount rates (reprinted in format 15). The model selects plants in order of their delivered energy costs until the demand is satistied. It quite otten happens that the tinal plant is only partially loaded. In the event of partial loading, a number of possible supply and demand options can be studied in new scenarios. Partial loading is highlighted by a note on Format 16 .

Format 17 shows the generation lost by derating the electrical power plants converted to district heating. For single-case turbines ${ }^{\dagger}$ whose capacity ${ }^{\dagger}$ is permanently reduced when used for district heating, the total permanently derated capacity also is reported. The report includes a credit for electricity displaced by the district system. Displacement of electrical demand occurs when, for example, absorption cooling in a district system replaces conventional electrical chillers. Although the stations ${ }^{\dagger}$ selected up to this point will meet the annual energy demands, they will generally fall short of the peak-load demand; therefore, the model next selects additional thermal-only peaking stations whose costs are included as part of the district heating system. Format 17 concludes with a summary of the annual and peak loads. 
Format 18 lists those stations that were not used for the district heating system either because their energy was not needed or their costs were too high. Also on this page may be. listed existing district steam-system plants that were not available because they supply areas outside the current scenario.*

The information in formats $15-18$ can have two functions. First, it can be the basis for starting an analysis of the availability of capitalcost financing, and it can be used to study whether cogeneration ${ }^{\dagger}$ using the selected power plants will have important effects on electric generating reserve margin. $\dagger^{\dagger}$ Moreover, the $\$ / M M B t u$ calculations can be used for comparison against current or projected costs of existing fuels. This comparison may be a marketing tool. Second, the data can be used in developing new scenarios. For example, the first scenario could be run using power-plant fuels that currently exist. The second scenario could test the effects of converting some or all units from using. a scarce fuel to using an abundant fuel. Comparisons and cost estimates for the switch could show the advantages or disadvantages involved in such a change. Data from the supply module can be fed automatically into the cost module and combined with data there to provide insights into financing issues.

\section{H.4 COST OUTPUT}

As in the supply module, the information in the cost module (formats 26-30) can be used to assess financial feasibility and to compare scenarios.**

The cost-module report (formats 25-30, with calculation results on 26-30) contains a variety of information useful in evaluating the economic attractiveness of a district heating system. The report begins on formats 25 and 26 by identifying the scenario (city, supply scenario, cost scenario) the various financial input data (provided in the supply module), and the calculated fixed charge rate. ${ }^{\dagger}$ After this introductory information, a table on format 26 reports district-heating-system costs by various components. The first line of this table gives the investment costs in mixed current dollars, i.e., the dollars spent from the startup year until the in-service date of the district heating eyetem $==$ including inflation and interest during construction, but without discounting. All of the other costs presented in this table are in dollars discounted to 1980 . The next line gives the total discounted lifetime capital costs (not including construction costs), followed by the discounted average annual costs, based

*Most of the information for Section 3.3 .2 to this point was provided by the Energy System Research Group.

**Cost-module input, other than current fuel prices (format 25), is from the demand and supply modules; thus, changes in the scenarios described in the earlier modules will be reflected in the cost output. Perhaps one of the more important scenario changes would come from changing the interest rate to reflect differences between public and private financing. Since capital carrying charges (i.e., costs of borrowing for the initial capital costs of district heating) are a large percentage of lifetime costs, $t$ a few percentage points in interest rate can make a difference in the final cost of energy delivered ( $\$$ /million $B t u$ ). 
on the user-specified system 1 ifetime. The 1 ifetime costs are divided by the annual final heat demand serviced by the system to give the average cost (per MMBtu) of meeting the demand requirements in the scenario service area. Similar results are reported for the variable costs, such as those for operating and maintenance and district-heating fuel use, and a final average total discounted cost of meeting final demand is reported. The cost per MMBtu listed at the bottom of format 26 is compared to alternate fuel costs shown in format 27 .

Formats 27 and 28 report the final demand and fuel consumption by building type and end-use.sector with the existing systems. This long table is divided into three major sections: (1) city-wide; before district heating; (2) the portion that is not district heated; and (3) the portion that is district heated. The sum of the second and third, equals the first. Within each section, columns 1 ist the annual final demands and fuel consumptions based on conversion efficiencies. For each building type and end-use sector, demand and fuel use are given for each fuel type as total and total on-site ${ }^{\dagger}$ (i.e., not including other fuel such as that used in electrical generation). For each end-use sector, a summary demand cost per MMBtu of final demand is reported. This is the average energy cost discounted to 1980 and weighted by the quantity of each fuel demanded. At the bottom of format 28, the totals for all buildings are reported.

Format 29 gives the year-by-year cash flow of costs and benefits for the district heating system. This is divided into two similar sections -the first section expressed in current dollars (dollars in the year they are spent) and the second expressed in 1980 dollars. The basis for these calculations are the O\&M and fuel-use calculations from the supply module, and the financial assumptions specified by the user.

Format 30 gives financial results starting with the 1980 . worth of the cumulative net 1 ifetime benefits (loss) of the district heating system. The second result is the savings-to-investment ratio, which is the ratio of the total system savings from decreased fuel and other. costs divided by the investment cost (all in 1980 dollars). This represents the relative economic benefit of the system and $c$ an be used to rank competing projects or scenarios. The third result is the discounted payback period, $t$ which reports how many years are needed for the savings to pay back the investment costs. Finally, the calendar year in which the cumulative net cash flows become positive is provided. The final section of format 30 provides a summary table of annual fuel consumption. before and after installation of district heating. The utility and on-site energy uses are listed individually and then totalled. The table is a summary of power-plant fuel use by fuel type -- before and after district heating -- for all plants listed in the supply input file. For most fuels there will be no change (if they are not selected for cogeneration operation in the district supply system); or there will be an increase because more fuel is consumed to provide district heating thermal energy. In some cases, if existing district steam plants are not selected for the district heating system, there may be a decrease in fuel consumption. Generally, the fuel used by a utility after district heating (usually coal) will decrease on a Btu basis to about half of the amount used before district heating, representing the greater thermal efficiency of the district heating system over electricity-only operation. 


\section{H.5 - EMISSIONS OUTPUT}

The emissions module calculates total air pollutant emissions (in tons per year) for sulfur oxides, nitrogen oxides, and particulate matter. These calculations are performed for:

1. Tonnage/year put into the air for heating demands served, before and after district heating has been installed for the community as a whole (format 24);

2. Tonnage/year before and after district heating for each electric generating plant (formats 31, 22), and the tonnage/year before and after district heating for each grid square (format 23).

These calculations can help show the decrease in emissions possible through implementation of more efficient, better maintained, and better controlled central-plant equipment in a district heating and cooling system. These data would be of primary interest to utility. officials interested in compliance by their plants to government standards, and to air-pollutioncontrol officials concerned with improving air quality. 
THIS PAGE

WAS INTENTIONALLY

LEFT BLANK 


\section{APPENDIX I \\ STANDARD INDUSTRIAL AND COMMERCIAL/INSTITUTIONAL \\ CLASSIFICATION CODES: TWO SECTORS OF POTENTIAL IMPORTANCE FOR DHSM INPUT AND OUTPUT DATA}

DHSM input and output data are divided into four major classes by land use and building type:

1. Residential, low density;

2. Residential, high density;

3. Commercial/institutional; and

4. Industrial.

The two residential densities are defined in Appendix A. The industrial and commercial/institutional classes, whose major groups are distinguished by individual SIC code numbers, are described below. The major groups in these two types of community land use constitute potential users of the energy produced by a district heating and cooling system.

INDUSTR I,AI.

Division C. Construction

Major group 15. Building construction - general contractors and operative builders

Major group 16. Construction other than building construction general contractors

Major group 17. Construction - special trade contractors

Division D. Manufacturing

Major group 20. Food and kindred products

Major group 21. Tobacco manufactures

Major group 22. Textile mill products

Major group 23. Apparel and other finished products made from fabrics and similar materials

Major group 24. Lumber and wood product, except furniture.

Major group 25. Furniture and fixtures

Major group 26. Paper and allied products

Major group 27. Printing, publishing, and allied industries

Major group 28. Chemicals and allied products

Major group 29. Petroleum.refining.and related industries

Major group 30. Rubber and miscellaneous plastics products

Major group. 31. Leather and leather products

Major group 32. Stone, clay, glass, and concrete products

Major group 33. Primary metal industries

Major group 34. Fabricated metal products, except machinery and transportation equipment

Major group 35. Machinery, except electrical 
Major group 36. Electrical and electronic machinery, equipment, and supplies

Major group 37. Transportation equipment

Major group 38. Measuring, analyzing, and controlling instruments; photographic, medical and optical goods; watches and clocks

Major group 39. Miscellaneous manufacturing industries

\section{COMME RCIAL/INSTITUT IONAL}

Division E. Transportation, communications, electric, gas, and sanitary services

Major group 40. Railroad transportation

Major group 41. Local and suburban transit and interurban highway passenger transporcation

Major group 42. Motor freight transportation and warehousing

Major group 43. U.S. Postal Service

Major group 44. Water transportation

Major group 45. Transportation by air

Major group 46. Pipe lines, except natural gas

Major group 47: Transportation services

Major group 48. Communication

Major group 49. Electric, gas, and sanitary services

Division F. Wholesale trade

Major group 50. Wholeoale trade - durable goods

Majus gluup 51. Wiolesale trade - nondurable goodo

Division G. Retail trade

Major group 52. Building materials, hardware, garden supply, and mobile home dealers

Major group 53. General merchandise stores

Major group 54. Food stores

Major group bל. Automotive dealers and gasolíne service scations

Major group 56. Apparel and accessory stores

Major group 57. Furniture, home furnishings, and equipment stores

Major group 58. Eating and drinking places

Major group 59. Miscellaneous retail

Division H. Finance, insurance, and real estate

Major group 60. Banking

Major group 61. Credit agencies other than banks

Major group 62. Security and commodity brokers, dealers, exchanges, and services

Major group 63. Insurance

Major group 64. Insurance agents, brokers, and service

Major group 65. Real estate 
Major group 66. Combinations of real estate, insurance, loans law offices

Major group 67. Holding and other investment offices

\section{Division I. Services}

Major group 70. Hotels, rooming houses, camps, and other lodging places

Major group 72. Personal services

Major group 73. Business services

Major group 75. Automotive repair, services, and garages

Major group 76. Miscellaneous repair services

Major group 78. Motion pictures

Major group 79. Amusement and recreation services, except motion pictures

Major group 80 . Health services

Major group 81 . Legal services

Major group 82. Educational services

Major group 83. Social services

Major group 84. Museums, art galleries, botanical and zoological gardens

Major group 86. Membersip organizations

Major group 89. Miscellaneous services

Division J. Public administration

Major group 91. Executive, legislațive, and general government, except finance

Major group 92. Justice, public order, and safety

Major group 93. Public finance, taxation, and monetary policy

Major group 94. Administration of human resources programs

Major group 95. Administration of environmental quality and housing programs

Major group 96. Administration of economic programs

Major group 97. National security and international affairs

Division K. Nonclassifiable establishments

Major group 99. Nonclassifiable establishments 